\title{
Facies interpretation and regional stratigraphic study of the Upper Devonian Gordon zone and associated beds in northern West Virginia and southwestern Pennsylvania
}

\author{
James H. Moore III \\ West Virginia University
}

Follow this and additional works at: https://researchrepository.wvu.edu/etd

\section{Recommended Citation \\ Moore, James H. III, "Facies interpretation and regional stratigraphic study of the Upper Devonian Gordon zone and associated beds in northern West Virginia and southwestern Pennsylvania" (2009). Graduate Theses, Dissertations, and Problem Reports. 2823. \\ https://researchrepository.wvu.edu/etd/2823}

This Thesis is protected by copyright and/or related rights. It has been brought to you by the The Research Repository @WVU with permission from the rights-holder(s). You are free to use this Thesis in any way that is permitted by the copyright and related rights legislation that applies to your use. For other uses you must obtain permission from the rights-holder(s) directly, unless additional rights are indicated by a Creative Commons license in the record and/ or on the work itself. This Thesis has been accepted for inclusion in WVU Graduate Theses, Dissertations, and Problem Reports collection by an authorized administrator of The Research Repository @ WVU. For more information, please contact researchrepository@mail.wvu.edu. 
Facies Interpretation and Regional Stratigraphic Study of the Upper Devonian Gordon Zone and Associated Beds in Northern West Virginia and Southwestern Pennsylvania

\author{
James H Moore III
}

\author{
Thesis Submitted to the \\ College of Arts and Sciences \\ at West Virginia University \\ in Partial Fulfillment of the Requirements \\ for the Degree of \\ Master of Science \\ In Geology \\ Dr. Richard Smosna, Chair \\ Dr. Thomas Kammer, Ph.D. \\ Patrick McBride, MS
}
Department of Geology and Geography West Virginia University Morgantown WV 2009

Keywords: Upper Devonian, Catskill Delta Complex, Gordon Sandstone, Gordon Stray Sandstone, Fifty Foot Sandstone, Gantz Sandstone Copyright 2009 James H. Moore III 


\title{
ABSTRACT \\ Facies Interpretation and Regional Stratigraphic Study of the Upper Devonian Gordon Zone and Associated Beds in Northern West Virginia and Southwestern Pennsylvania.
}

\author{
James H Moore III
}

Subsurface correlation of 250 well logs and isopach mapping of Upper Devonian beds across western Pennsylvania and northern West Virginia have been coupled with a core study in Washington County, Pennsylvania, to determine the nature and distribution of the Upper Devonian Gordon zone. The complete stratigraphic section studied includes the Fifth, Fourth, Gordon, Gordon Stray, Thirty Foot, Fifty Foot, and Gantz beds. Along with isopach maps, net sandstone maps were generated for improved characterization of sandstone geometry and facies distribution across the field area. Cross-sections including four west to east and one north to south were constructed to aid in stratigraphic analysis. The resultant sediment distribution patterns with the developing Late Famennian foreland basin were dominantly barrier bar and delta front environments. The evaluation of net sandstone geometries suggests that these depositional systems were influenced by a combination of structural features related to the Rome Trough graben fault system, and eustatic fluctuations. Two major fault boundaries along the length of the Rome Trough in western Pennsylvania and northern West Virginia influenced deposition and position of the shorelines in the late Famennian by creating continuous accommodation space. This resulted in the stacking of shoreline sandstone across the field area. In addition, isopach maps and cross-sections show that the Gordon Stray shorelines jumped substantially to the west correlating with a global sea level drop during Gordon Stray deposition. The influence of structural features may have not been as prominent to the south. 


\section{TABLE OF CONTENTS}

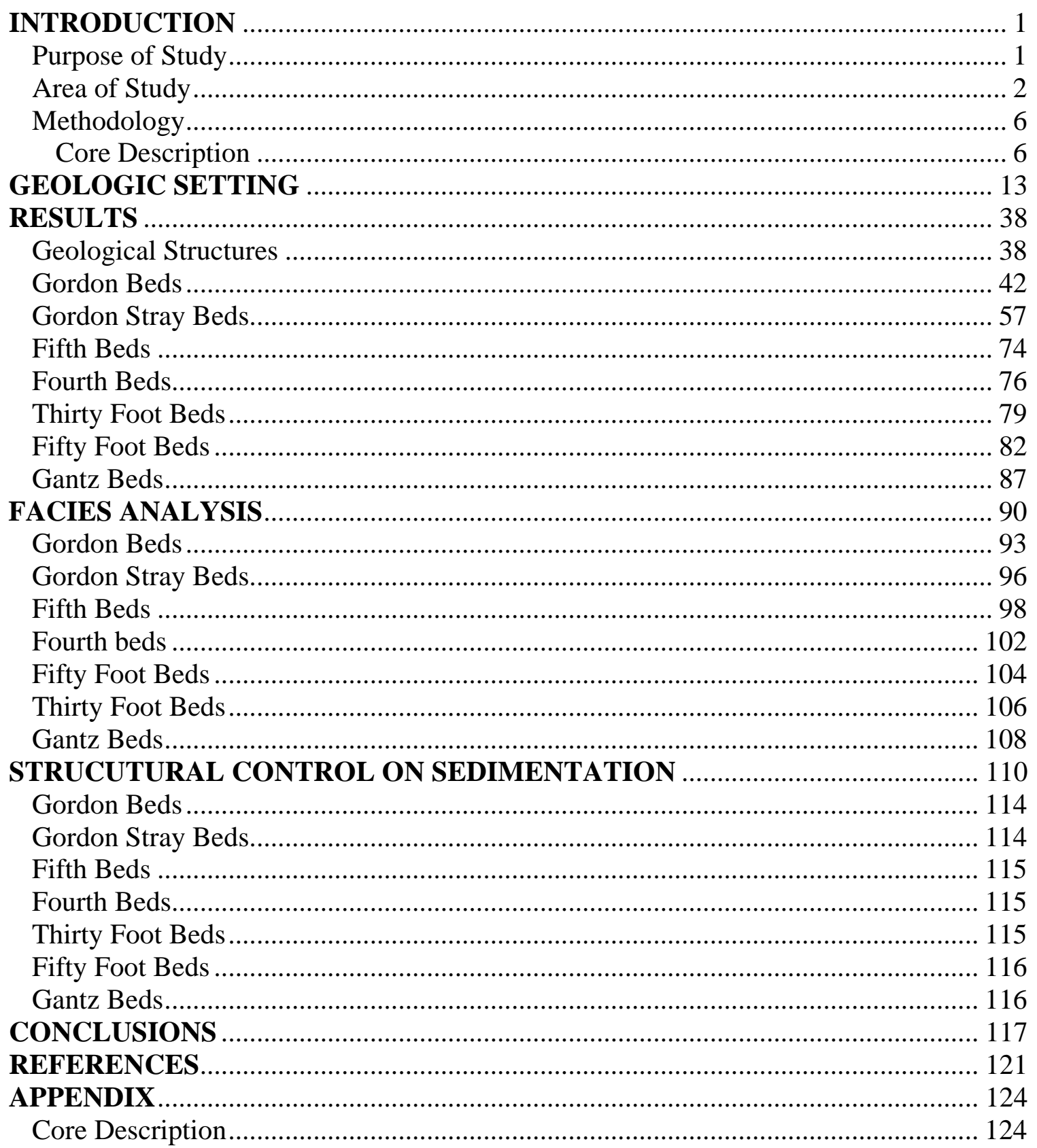




\section{LIST OF FIGURES}

Figure 1. Map showing location of study area. Line A-A' represents the general trend of this stratigraphic study. The red dot represents the location of the core studied. Blue dots represent wells with logs.

Figure 2. Producing areas from the Gordon zone in northern West Virginia and Pennsylvania. From Aminian et al. 2001.

Figure 3. Map displaying major structural features in northern West Virginia. Black area shows the approximate position of the Jacksonburg-Stringtown field. From Aminian et al. 2001

Figure 4. Stratigraphic column displaying Gordon Stray beds in core. Scale is in feet. ... 7

Figure 5. Stratigraphic column and gamma-ray curve of the Gordon Stray beds in Wetzel County, West Virginia. From McBride (2004)......

Figure 6. Well log from Lewis \#1 in central Greene County, Pennsylvania, 10

Figure 7. Base map showing the location of cross sections. Dots represent well locations.

Figure 8. Cross-section of the Acadian clastic wedge illustrating the Catskill Delta Complex and the progradation of the Venango formation.The Gordon Zone is near the top of the Venango. From Boswell et al. (1996). 14

Figure 9. Isolith map of the Gordon zone in the central Appalachian Basin. (Right)Paleographic resconstruction of the Catskill Delta Complex. The Preston deltaic apron can be seen in the southern portion of the map and is labeled (3). From Boswell and Donaldson 1988 16

Figure 10. (Left) Isolith map of the Gordon zone during Late Famennian time in northern West Virginia. Facies $\mathrm{A}=$ Greenland Gap Formation, Facies $\mathrm{B}=$ Venango Formation, Facies $\mathrm{C}=$ Rowlesburg Formation (Right) Lithofacies map for Gordon zone. From Boswell and Donaldson 1988.

Figure 11. Devonian stratigraphic units in the subsurface of Pennsylvania. From Harper and Laughrey (1987).

Figure 12. Isopach map of Gordon Stray beds in northern West Virginia showing barrier bar to the east. Modified from McBride and Smosna (2005)

Figure 13. Cross-section showing the distribution of informal sandstone zones in the Upper Devonian of West Virginia. The Gordon Stray sandstone is located near the top of the Venango Formation. From Boswell and Jewell

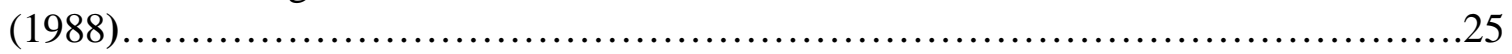


Figure 14. Cores of the Gordon Stray. $A=$ shale of the inner shelf with sand ripples and small sand filled horizontal burrows, $\mathrm{B}=$ fine-grained sandstone of the lower-shoreface with horizontal laminations. $\mathrm{C}=$ inter-bedded conglomerate and medium-grained sandstone of the foreshore with horizontal stratification, $\mathrm{D}=$ medium to very coarsegrained sandstone of the upper-shoreface displaying large-scale planar cross-bedding. Modified from McBride and Smosna (2005). 25

Figure 15. Cores of the Gordon Stray, $A=$ Heterolithic bioturbated lithofacies, $B=$ conglomerate sandstone lithofacies, $\mathrm{C}=$ featureless sandstone lithofacies. From Ameri et.al (2001) 27

Figure 16. Thickness of Gordon zone in West Virginia and Pennsylvania. From Boswell et al, 1996.

Figure 17. East-west gamma-ray cross-section illustrating the subsurface stratigraphy of northern West Virginia, and correlation to outcrops in Rowlesburg, Preston, County West Virginia. Venango Formation is shaded black. Boswell and Jewell (1988).................... 31

Figure 18. (left) Stratigraphic position of upper Devonian sandstone units in northern West Virginia. Gordon sandstone and upper Gordon Stray (in black) can be observed near the middle of the illustration. (Right) Isopach map of the Gordon zone displaying S2 configuration. From Boswell, et al. (1987). 31

Figure 19. Isopach map showing Gordon Stray sandstone thickness and distribution in northern West Virginia. From Boswell, et al. (1987). 32

Figure 20. Typical well log in the Donegal storage field of southwestern Pennsylvania. Gordon Stray (target sandstone) occurs at approximately $2650 \mathrm{ft}$. From McCallister et al. (2001). Two stacked channels are evident from both gamma-ray and density curves..... 36

Figure 21. Structure map on top of the Gordon Stray beds with approximate locations of suspected basement faults from Wagner (1977) and lineaments from Flaherty (1996)... 39

Figure 22. Tectonic and magnetic map showing positions of major lineaments and their associated depositional segments in West Virginia as they relate to the Rome Trough. The study area for this thesis is highlighted in yellow while major lineaments are colored red. Modified from (Gao et. al 2000)..... 41

Figure 23. Gross cross-section A-A' showing the distribution of Upper Devonian beds including the Gordon and Gordon Stray across northern Washington County. 43

Figure 24. Gross cross-section B-B' showing the distribution of Upper Devonian beds including the Gordon and Gordon Stray across northern Greene County. 44

Figure 25. Gross cross-section C-C' showing the distribution of Upper Devonian beds including the Gordon and Gordon Stray across southern Greene County. 45

Figure 26. Gross cross-section D-D" showing the distribution of Upper Devonian beds 
including the Gordon and Gordon Stray across southern Wetzel, and Marion Counties. 46

Figure 27. Gross cross-section N-N' showing the distribution of Upper Devonian beds from north to south including the Gordon and Gordon Stray across the field area..... 47

Figure 28. Gross cross-section N'-N" showing the distribution of Upper Devonian beds from north to south including the Gordon and Gordon Stray across the field area......... 48

Figure 29. Gross cross-section N"-N" showing the distribution of Upper Devonian beds from north to south including the Gordon and Gordon Stray across the field area. 49

Figure 30. Isopach map of Gordon beds. Dots represent data points. Contour interval is $5 \mathrm{ft}$.

Figure 31. Gordon net-sandstone map. Dots represent data points. Contour interval is 2 ft. Basement faults from Wagner (1977).

Figure 32. West to east cross-section C-C' showing the distribution of Gordon beds across southern Greene County. Yellow areas indicate sandstone with API values 80 API or less, and grey areas indicate shale with API values above 80. 53

Figure 33. Cross-section B-B' showing the distribution of the Gordon beds across northern Greene County. Orange areas represent sandstone with API values 80 API or less. Grey areas indicate shale with values greater than 80 API. 54

Figure 34. Cross-section D-D" showing the distribution of Gordon beds across Wetzel and Marion Counties West Virginia. Orange areas represent sandstone with API values 80 API or less. Grey areas indicate shale with values greater than 80 API. 56

Figure 35. Isopach map of Gordon Stray beds. Dots represent data points. Contour interval is $5 \mathrm{ft}$. 58

Figure 36. Gordon Stray net-sandstone map. Dots represent data points. Contour interval is $2 \mathrm{ft}$. Basement faults from Wagner (1977).

Figure 37. East to west cross-section C-C' showing the distribution of Gordon Stray beds across southern Greene County. Yellow areas indicate sandstone of 80 API or less. Grey areas represent shale with values higher than 80 61

Figure 38. Cross-section B-B' showing the distribution of Gordon Stray beds across northern Greene County. Yellow indicates sandstone with API values 80 API or less. Grey areas represent shale with values greater than 80 API.

Figure 39. East to West Cross-Section A-A' showing the distribution of the Gordon Stray beds across northern Washington County Pennsylvania. Yellow areas indicate sandstone of 80 API or less. Grey areas represent shale with values higher than 80 API. 63

Figure 40. Cross-section D-D"' showing the distribution of the Gordon Stray beds across 
Figure 41. Cross-Section A-A' showing the Gordon interval in the subsurface of northern Washington County Pennsylvania. Yellow colors indicate Gordon Stray beds. Orange colors indicate Gordon beds...... 65

Figure 42. Cross-section B-B' showing the Gordon interval across northern Greene County Pennsylvania. Yellow colors indicate Gordon Stray beds. Orange colors indicate Gordon beds. Grey area represents shale with gamma-ray API values greater than 80 API.

Figure 43. Cross-section C-C' showing the Gordon interval in the subsurface of southern Greene County Pennsylvania. Yellow colors indicate Gordon Stray beds. Orange colors indicate Gordon beds. 68

Figure 44. Cross section D-D" showing Gordon Interval across Wetzel and Marion Counties West Virginia. Yellow colors indicate Gordon Stray beds. Orange colors indicate Gordon beds. Grey areas indicate shale with values greater than 80 API. 69

Figure 45. Photo of the portion of the core studied showing the Gordon Stray beds...... 71

Figure 46. Gamma ray log (left) and FMI log (right) compared to the stratigraphic column constructed for the Gordon Stray core. Core depth differs from log depth by +10 ft. 72

Figure 47. Gordon Stray core. Image shows erosional contact at the base of unit 6, where conglomerate cuts into the grey fine sandstone of unit 5. Also shown is the gradational nature of unit 6 with conglomerate grading upward into sandstone. 73

Figure 48. Isopach map of Fifth beds. Dots represent data points. Contour interval is $5 \mathrm{ft}$.

Figure 49. Net sandstone map of Fifth beds in the study area. Dots represent data points. Contour interval is $5 \mathrm{ft}$. Basement faults from Wagner (1977). 77

Figure 50. Isopach map of Fourth beds. Dots represent data points. Contour interval is 5 ft. 78

Figure 51. Net sandstone map of Fourth Beds in the study area. Dots represent data points. Contour interval is $3 \mathrm{ft}$. Basement faults from Wagner (1977)... 80

Figure 52. Isopach map of the Thirty Foot Beds. Black dots represent data points. Contour interval is $5 \mathrm{ft}$. 81

Figure 53. Net sandstone map of the Thirty Foot beds. Dots represent data points. Contour interval is $3.5 \mathrm{ft}$. 83

Figure 54. Isopach map of Fifty Foot beds. Dots represent data points. Contour Interval 
is $10 \mathrm{ft}$.

Figure 55. Net sandstone map of the Fifty Foot beds. Dots represent data points.

Figure 56. Isopach map of Gantz beds. Dots represent data points. Contour interval is 5 ft.

Figure 57. Net sandstone map of the Gantz beds. Dots represent data points. Contour interval is $5 \mathrm{ft}$.

Figure 58. Common gamma-ray patterns and their associated possible facies. From Cant (1991). 91

Figure 59. Examples of gamma ray patterns from wells in the study area, and possible depositional environments. 92

Figure 60. Sketch showing major sub-environments of a barrier island system. 94

Figure 61. Paleogeographic reconstruction of the Gordon beds. 95

Figure 62. Paleogeographic reconstruction of Gordon Stray beds. Triangle represents core location.

Figure 63. Illustration of a mixed (left) and a fluvial (right) dominated delta environment. The fluvial dominated delta on the right represents the modern Mississippi delta. Modified from Davis (1983).

Figure 64. Paleogeographic reconstruction of the Fifth beds. 101

Figure 65. Paleogeographic reconstruction of the Fourth beds. 103

Figure 66. Paleogeographic reconstruction of the Fifty Foot beds. 105

Figure 67. Paleogeographic reconstruction of the Thirty Foot Beds. 107

Figure 68. Paleogeographic reconstruction of the Gantz beds. 109

Figure 69. West-east cross section (A-A') showing abrupt thickening of sandstone beds across the study area and aproxamate position of basement faults in the study area. .... 111

Figure 70. Map displaying approximate positions of paleoshorelines during late Devonian time in relation to the Cambrian and Ordovician basement faults from Wagner (1977). Approximate position of paleoshorelines based on western most extent of sandstone.

Figure 71. Euramerica sea level curve through the Late Devonian and corresponding cronostratigraphic position of sandstone beds. Bed positions adopted from Boswell and Donaldson (1988). Euramerican sea level curve from Johnson and others (1984). ....... 113 


\section{ACKNOWLEDEGMENTS}

I would like to express my sincerest gratitude and thanks to my advisor Dr. Richard Smosna. He has been a source of great inspiration and knowledge throughout my career at West Virginia University. I would also like to thank Dr. Thomas Kammer and Mr. Patrick McBride for there ongoing support and insight throughout the thesis process. I would also like to thank my mother, father and my sister. There unconditional support throughout my life has led me to this moment and without them none of this would have been realized.

Finally, I would like to thank my wife Jessica. She has been by my side throughout this process and has been the cornerstone that has kept me strong. She not only provided inspiration and support throughout, but also completed my life. After all what is success if there is no one to share it with? JJ Always. 


\section{INTRODUCTION}

Upper Devonian Venango reservoirs have been major oil and gas producers since the 1850s. In fact, petroleum production in North America began in 1859 from a shallow coarse-grained sandstone at the top of the Venango play in the Drake well of Venango County, northwestern Pennsylvania. Within ten years of this initial find, 5500 wells, 1186 of which were producers, had been drilled within the county. In 1886 Washington County, Pennsylvania, became attractive to drillers when a well on the Gordon farm showed an initial production (IP) of 600 barrels of oil per day (bpd) from a shallow Venango sandstone at a depth of $2392 \mathrm{ft}$. Making history, this well became the world's deepest producing well at the time (Boswell et al. 1996).

By the early 1900s, production from the Venango play was on a decline. In recent years, the contribution of the Venango play has been mainly to provide subsidiary production in wells targeted for other reservoirs. Production has been limited to small pockets of bypassed reserves, gas storage, and enhanced recovery. However, Venango reservoirs such as the Fifth and Bayard are producers to the east, and exploration for sandstones of the upper Venango such as the Gordon Stray continues to this day (Boswell et al. 1996).

\section{Purpose of Study}

The primary focus of this thesis research is to determine facies and sandstonedistribution patterns of the Upper Devonian Gordon and Gordon Stray beds (Together called the Gordon zone) in southwest Pennsylvania and northern West Virginia. Some work has been done on the Gordon Stray beds in northern West Virginia by Boswell et al. (1987), McCallister et.al. (2001), and McBride and Smosna (2005); however little has 
been done in the way of a stratigraphic study of the Gordon zone in a regional sense. This thesis should provide further insight into these reservoirs for future development, namely better prediction and placement of exploratory wells in the central Appalachian basin. To insure accuracy and consistency in the required correlations, the entire stratigraphic section between the Fifth sandstone and the overlying Gantz sandstone was analyzed.

\section{Area of Study}

For purposes of this study, the area of interest covers six counties, Wetzel, Marshall, Monongalia and Marion Counties, West Virginia, and Greene and Washington Counties, Pennsylvania (Fig.1). The area of interest was chosen because of (1) a Gordon Stray core donated for study, (2) a large number of available well logs, and (3) known past production in the sandstone reservoir (Fig. 2). In Washington County, Pennsylvania, the Donegal storage field is a depleted production field which was developed from 1907 into the early 1920's and was converted to storage in 1941. In 2001, Design Day Deliverability was 190 million cubic feet per day (MMcf/D), and the field had a storage capacity of 9.5 billion cubic feet with 3.6 Bcf working gas (McCallister et al. 2001).

In northern West Virginia, data were taken from the Jacksonburg-Stringtown field in Wetzel County. The Stringtown field was discovered in 1895. Located on the western flank of the Burchfield Syncline, the field is contained within Wetzel, Tyler, and Doddridge counties, West Virginia (Fig. 3). Between 1897 and 1901, over 500 wells were drilled. , However, most of these wells were plugged by 1910 . Initially, the average production potential for these wells was 72 barrels of oil per day (BOPD). 


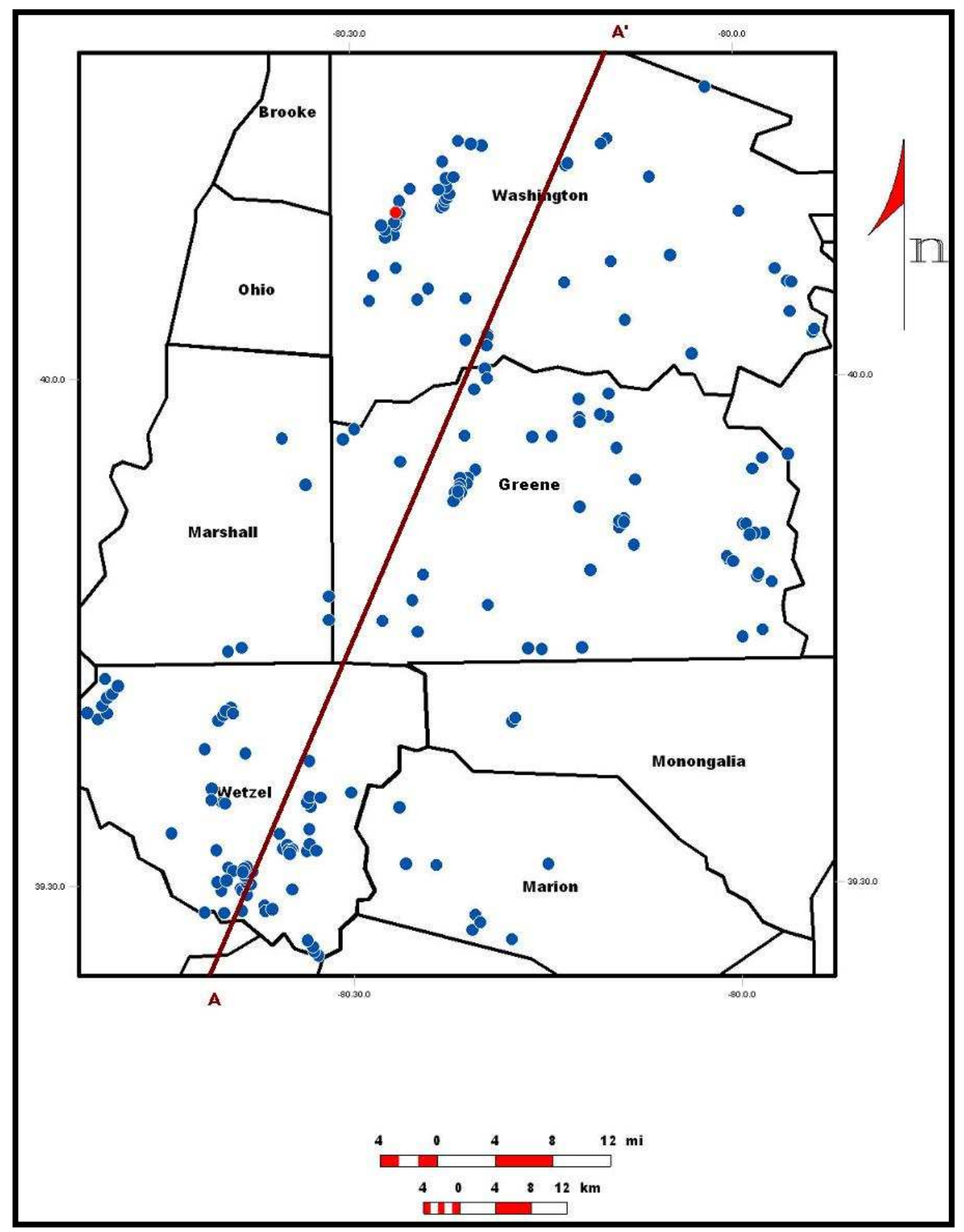

Figure 1. Map showing location of study area. Line A-A' represents the general trend of this stratigraphic study. The red dot represents the location of the core studied. Blue dots represent wells with logs. 


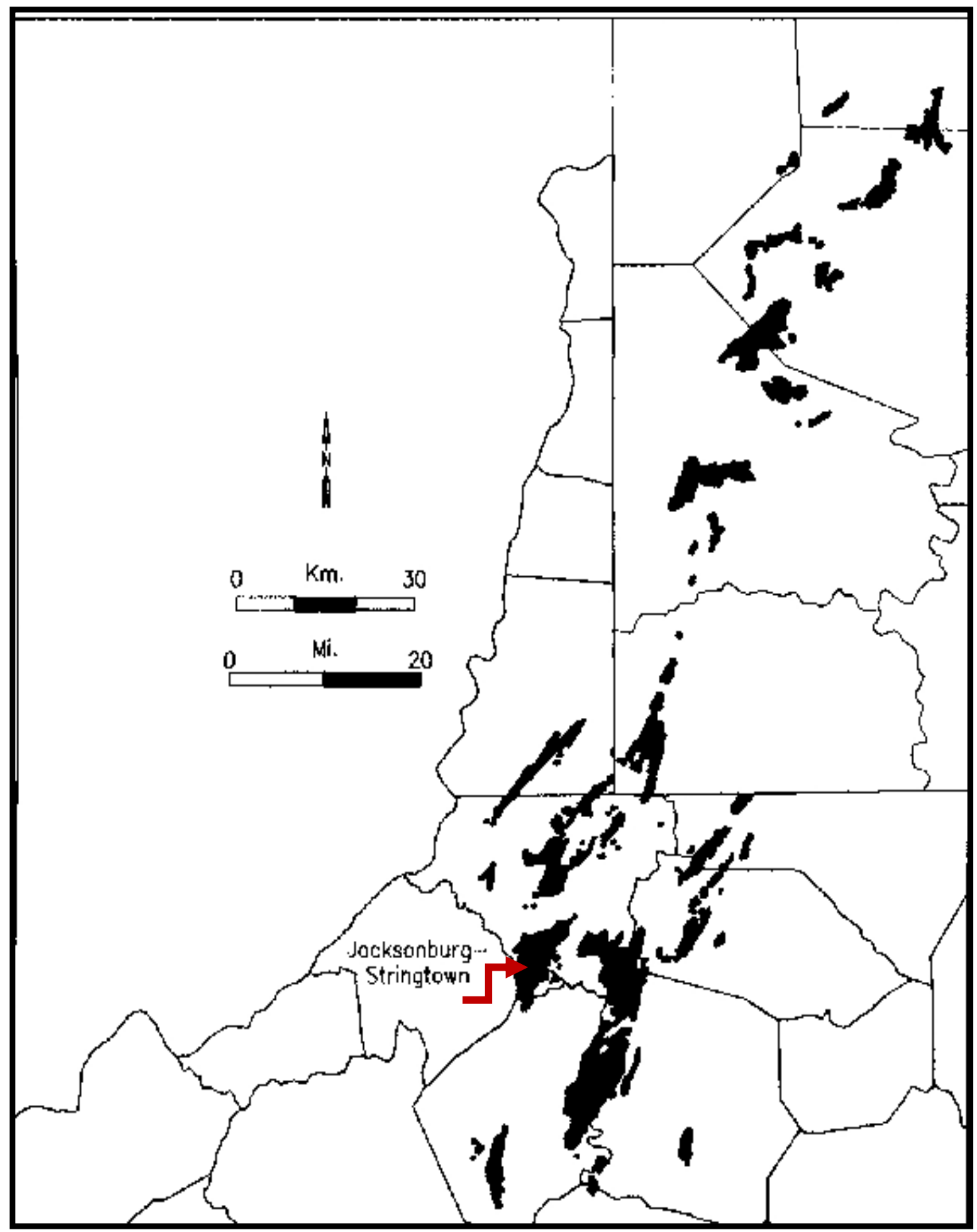

Figure 2. Producing areas from the Gordon zone in northern West Virginia and Pennsylvania. From Aminian et al. 2001. 


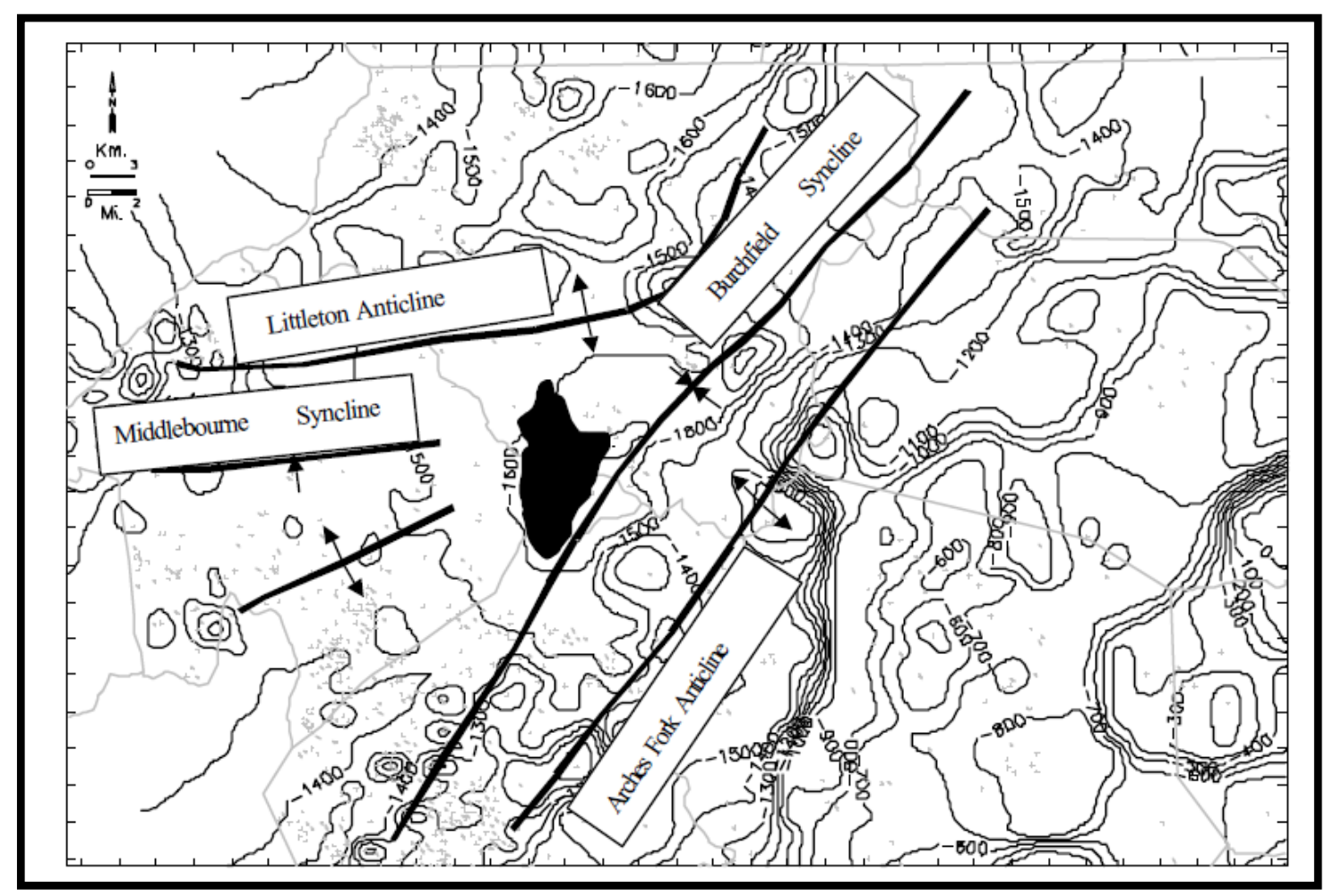

Figure 3. Map displaying major structural features in northern West Virginia. Black area shows the approximate position of the Jacksonburg-Stringtown field. From Aminian et al. 2001. 
Various stimulation methods including nitroglycerine stimulation, gas injection and water a water-flooding program was installed for the Gordon zone, and an average of 1300 barrels of oil per acre (BOPA) was recovered over four years. Full-scale water flooding began in 1990. Over 100 new wells have been drilled for water injection, and 40 more have been drilled for production. From 1990 to 2001, 1,864782 barrels of oil have been recovered from the Stringtown field (Aminian et.al, 2001).

\section{Methodology}

Core description

A full-bore core of the Gordon Stray beds, $119.7 \mathrm{ft}$. in length and taken in southwestern Pennsylvania, was described inch by inch, paying close attention to rock type, texture, grain size, bedding, sedimentary structures, and fossil content. Sedimentary structures, such as ripple marks, flaser and lenticular bedding, soft-sediment deformation, and cross-bedding, were noted. The nature of the contacts and potentially significant bedding surfaces were also described. Body and trace fossils were described as well. Detailed lithofacies were delineated and compiled into major units, and a representative stratigraphic column was created (Fig. 4).

The resultant stratigraphic column was then compared to the gamma-ray log taken when the core was drilled. Also included is a Formation Micro Imaging (FMI) log. This $\log$ allows for further detailed study of the bedding and lithology changes that are present in the core but difficult to see with a hand lens. The facies and stratigraphic patterns observed in the core were then compared to the observations of McBride (2004). 


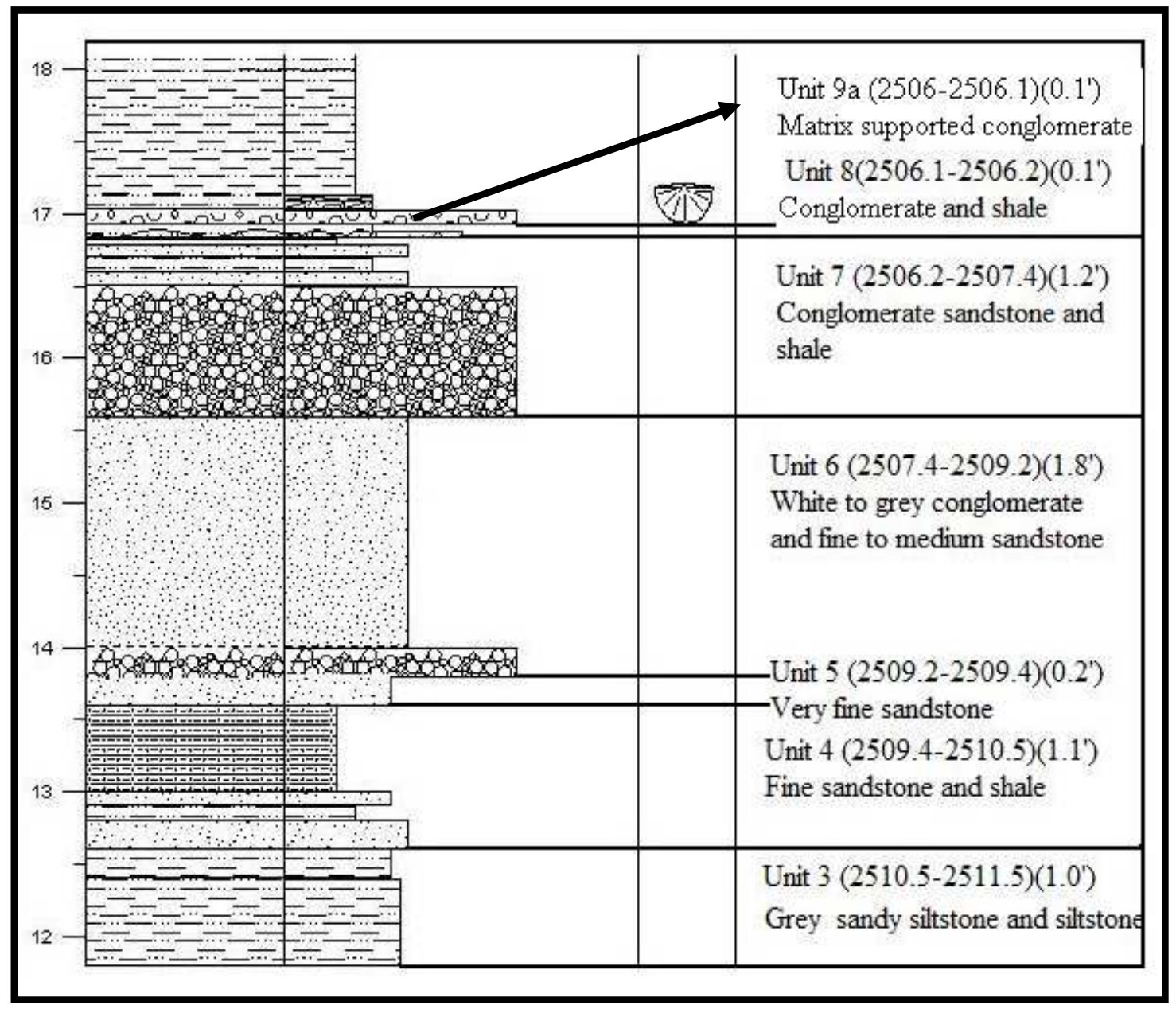

Figure 4. Stratigraphic column displaying Gordon Stray beds in core. Scale represents thickness and is in feet. 


\section{Subsurface Mapping}

Data from 250 well logs were collected from the West Virginia Geological survey and Pennsylvania Geological Survey were imported into a new project created in GeoGraphix. Well data include geographic coordinates (latitude and longitude), header information, and geophysical logs such as gamma-ray, resistivity, bulk density and/ or compensated density, neutron, density porosity, and temperature. About 30 logs donated by Chesapeake Energy were available digitally (LAS format) and were automatically imported into the project. The remainder of the logs were available only as raster (.tiff) images that were manually depth registered into the project. Following data entry, the top and base of the Gordon and Gordon Stray beds were picked following the criteria and type logs of McBride (2004)(Fig. 5) and log responses of the Gordon Stray from the core. Tops and bottoms were also picked for Fifth, Fourth, Thirty Foot, Fifty Foot, and Gantz beds (Fig. 6)

Key marker beds used for correlation included the bases of the Lower Mississippian Big Injun, Squaw and Berea Sandstones. Other local marker beds included a hot shale zone just below the Berea sandstone in Wetzel County. Laterally persistent throughout Wetzel County, this bed served as a helpful marker bed indicating stratigraphic position within the Devonian strata. The top of the Hundred Foot (FiftyFoot/Gantz) beds also served as a marker bed throughout the central and eastern portions of the study area. Once tops were established, correlations were made in a radial pattern outwards from well to well. Where digital data were unavailable, paper logs and field notes (donated from a proprietary source) on the subsurface characteristics of the Gordon Zone were utilized for correlation purposes. 


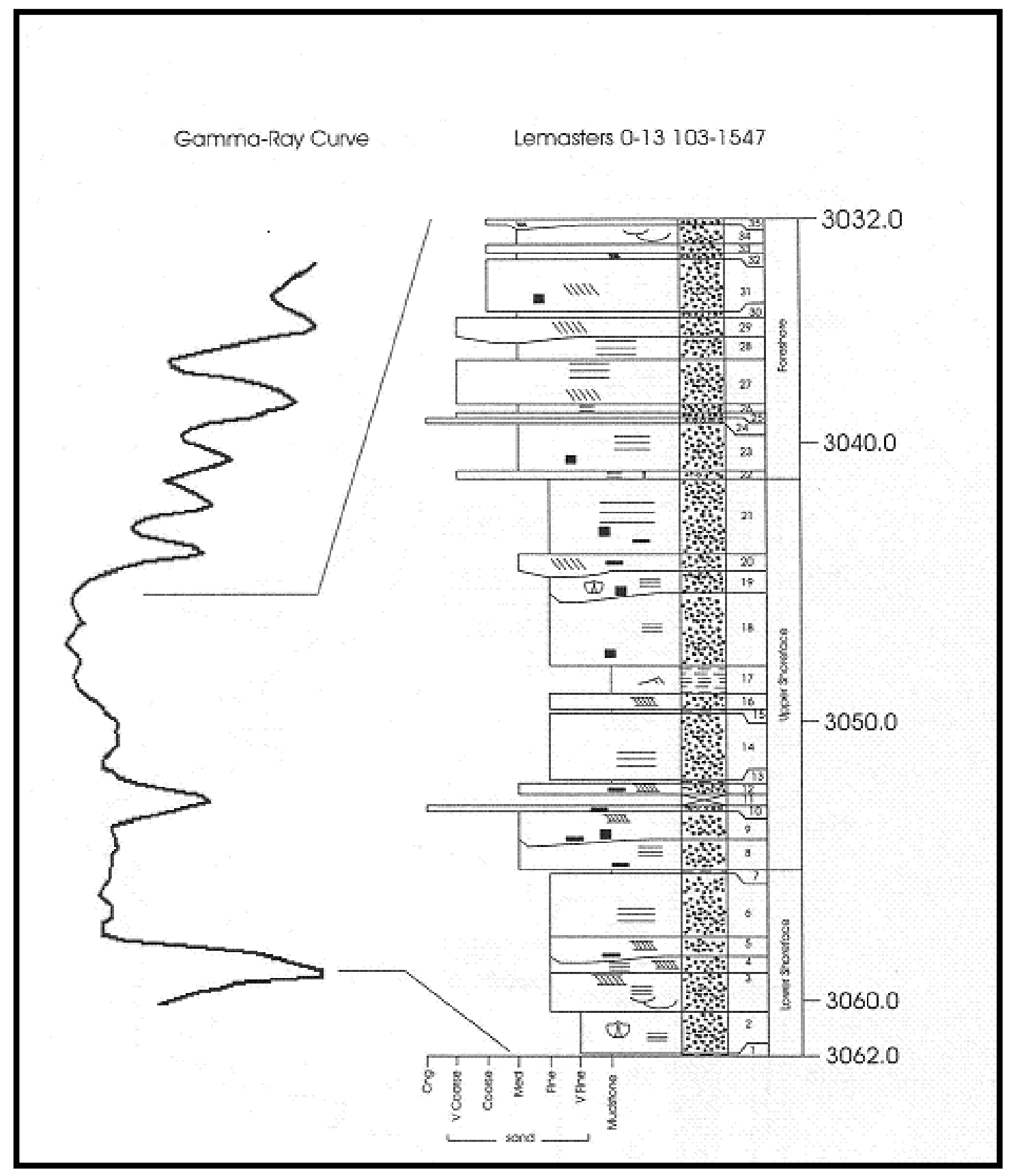

Figure 5. Stratigraphic column and gamma-ray curve of the Gordon Stray beds in Wetzel County, West Virginia. From McBride (2004). 


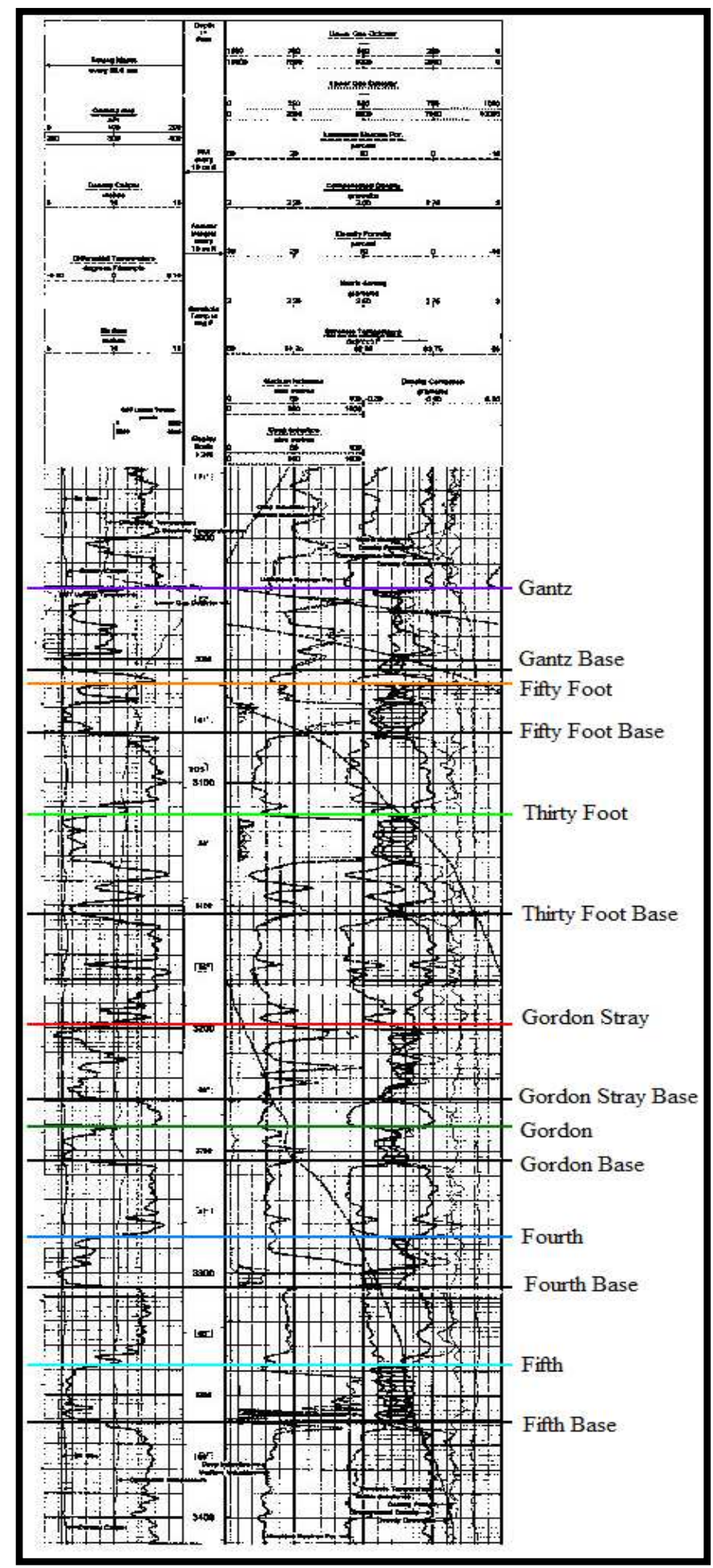

Figure 6. Well log from Lewis \#1 in central Greene County, Pennsylvania, showing stratigraphic picks and relationship between each bed mapped in this thesis. 
These data consist of datum, latitude, longitude, top/base, and thickness of the Gordon beds. From these data, one north-south and four east-west cross-sections were constructed across Wetzel, Monongalia, and Marion counties, West Virginia, and Washington and Greene counties Pennsylvania (Fig 7). In addition to the cross-sections, structure, isopach, and net sandstone maps were created. The core and subsurface data were synthesized and placed into a stratigraphic framework. 


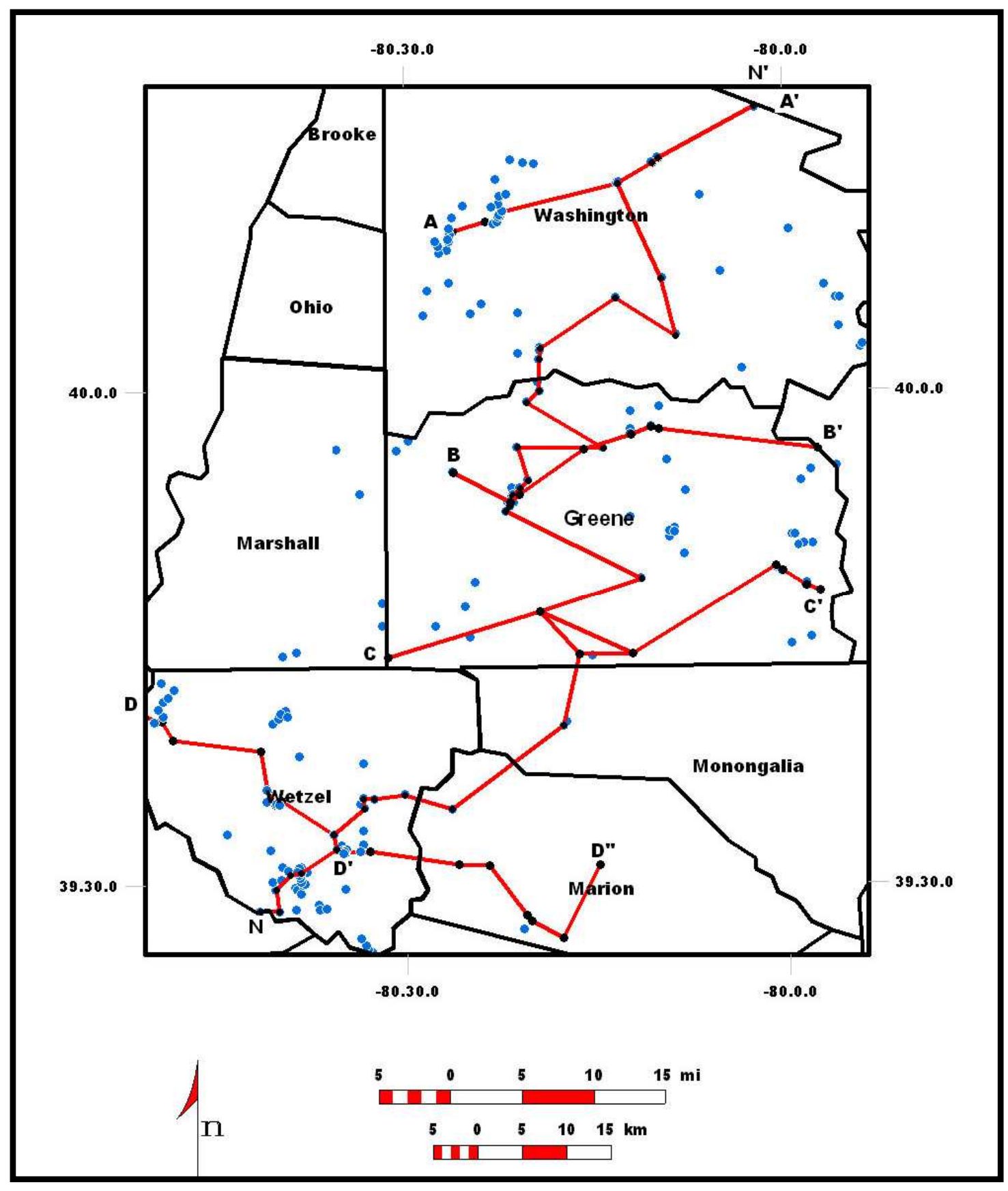

Figure 7. Base map showing the location of cross-sections. Dots represent well locations. 


\section{GEOLOGIC SETTING}

During Middle to Late Devonian time, plate interactions along the eastern margin of North America produced an elongate belt of folded and thrusted mountains, the Acadian chain. Tectonic loading associated with this orogenic event induced a high rate of subsidence within the adjacent craton, generating the linear Appalachian foreland basin. In the late Famennian, large volumes of coarse sediment were eroded from the newly raised mountains and transported into the basin to the west. Rocks of the Upper Devonian in the Appalachian basin formed as marine, transitional-marine, and nonmarine deposits and comprise the Acadian clastic wedge (Fig. 8). In the subsurface of northwestern West Virginia and southwestern Pennsylvania, Upper Devonian rocks consist of five magnafacies including black shale of the anaerobic basin center, turbidites of the basin floor and slope, fine-grained sediments of an open-marine storm-dominated shelf, coarse-grained sediments of deltaic environments, and terrestrial red beds ( Harper and Laughrey, 1987). 


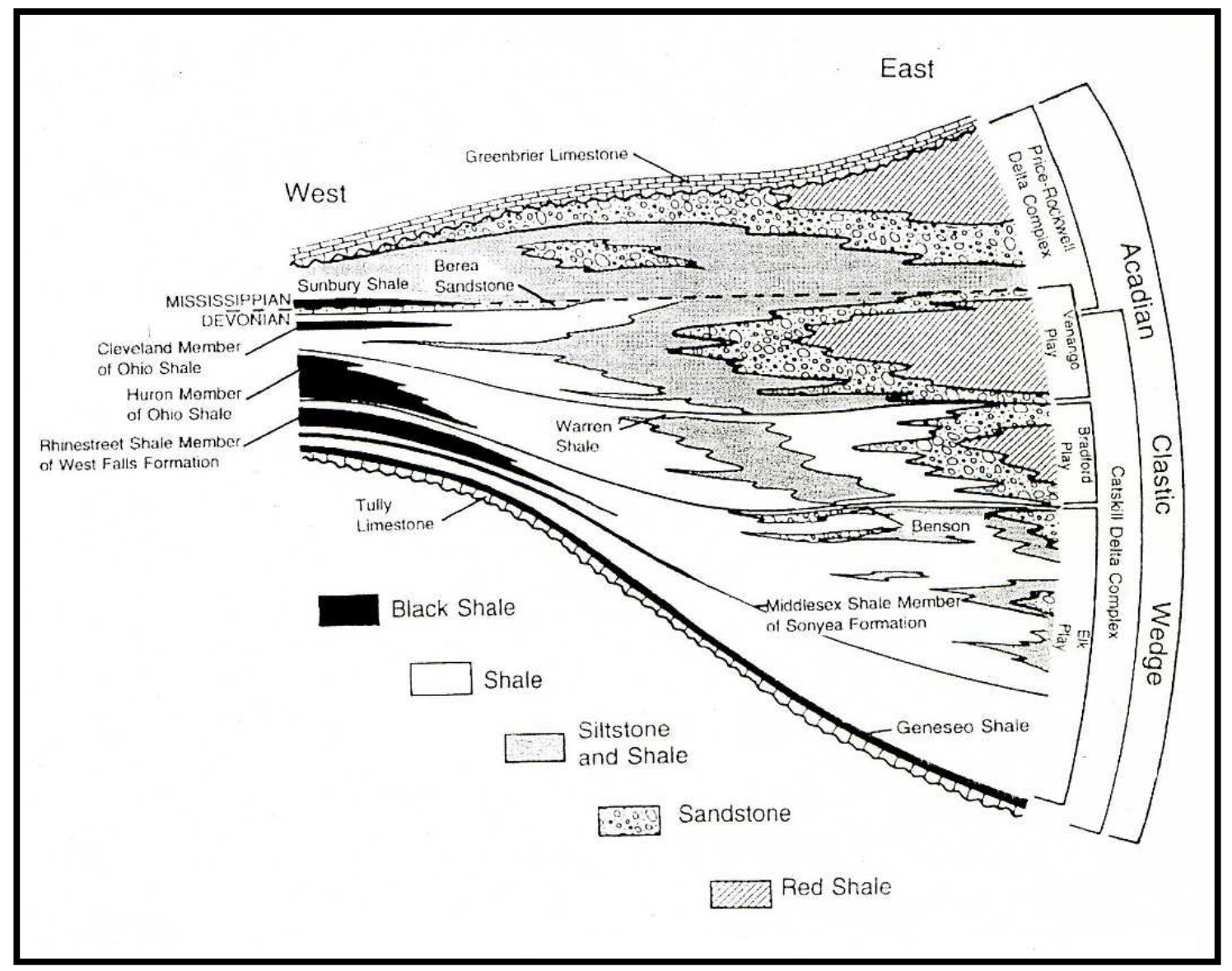

Figure 8. Cross-section of the Acadian clastic wedge illustrating the Catskill delta complex and the progradation of the Venango Formation. The Gordon zone is near the top of the Venango. From Boswell et al. (1996) 
Deposition of these facies occurred primarily along a broad coastal plain where at least four fluvial-deltaic aprons comprised the large prograding Catskill delta complex (Fig. 9). This complex extended from New York south to Virginia (Boswell and Donaldson 1988). Of these four deltaic aprons, the Preston system has been studied and described in detail by Boswell and Donaldson (1988). Located in northern West Virginia, the Preston deltaic-fluvial apron can be recognized in several stratigraphic intervals including the Gordon zone of late Famennian time. The Gordon zone is time equivalent to the Upper Rowlesburg, Greenland Gap, and Venango Formation, (Fig 10).

In the type area of Venango County, the Venango Group is defined as all of the strata between the Woodcock sandstone below (also known as the Venango First sandstone), and the Panama Conglomerate above (also known as the Venango Third sandstone (Harper and Laughrey 1987). In general terms, however, this zone is described as all of the strata from the base of the Oswayo Formation downward to the top of the Chadakoin Formation (Fig. 11). The Venango Group thickens to the southeast across Pennsylvania, and as it thickens, it acquires sandstones such as the Fourth, Fifth, Bayard, and Elizabeth. 


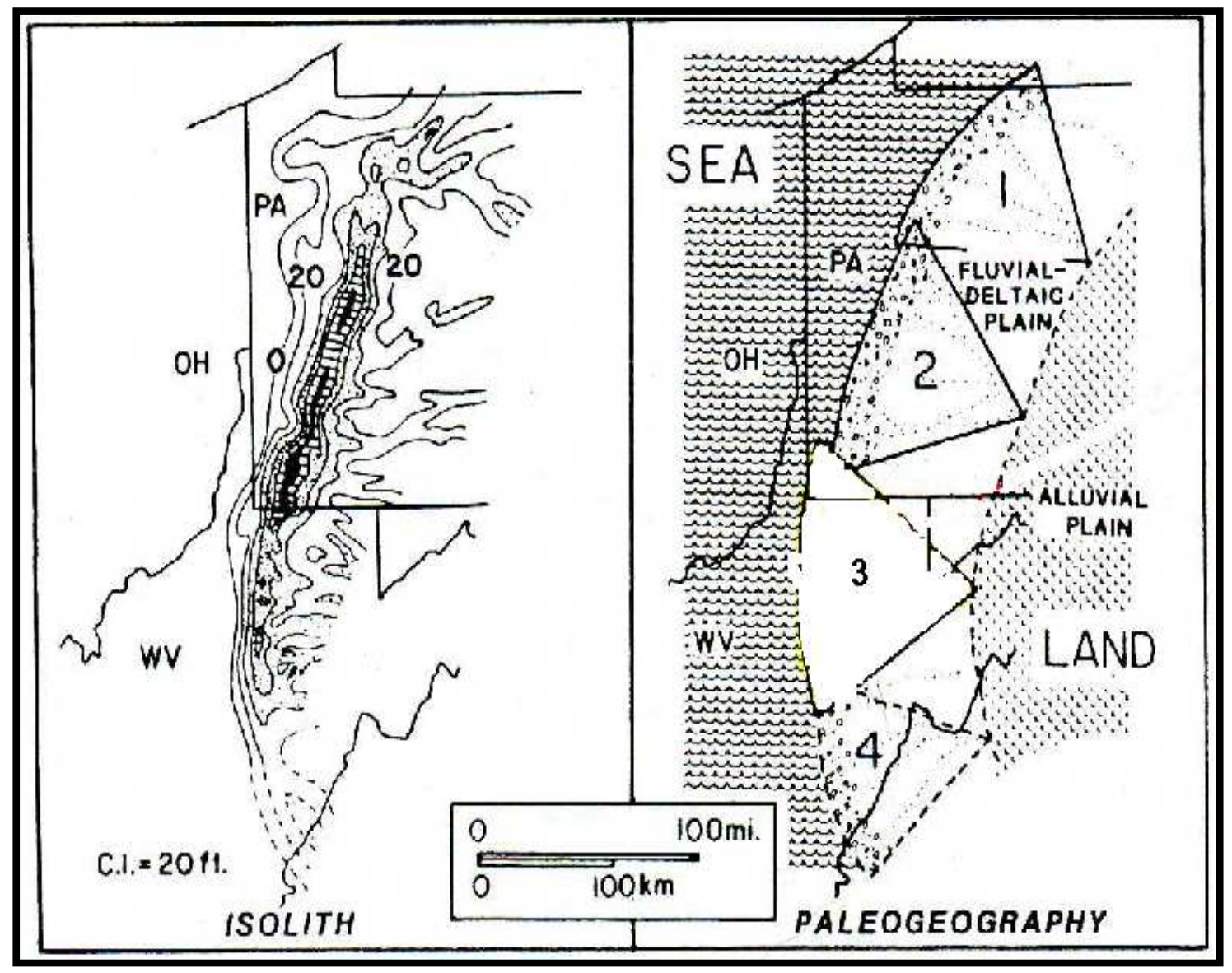

Figure 9. (Left) Isolith map of the Gordon zone in the central Appalachian Basin. (Right) Paleographic resconstruction of the Catskill delta complex. The Preston deltaic apron can be seen in the southern portion of the map and is labeled (3). From Boswell and Donaldson (1988). 


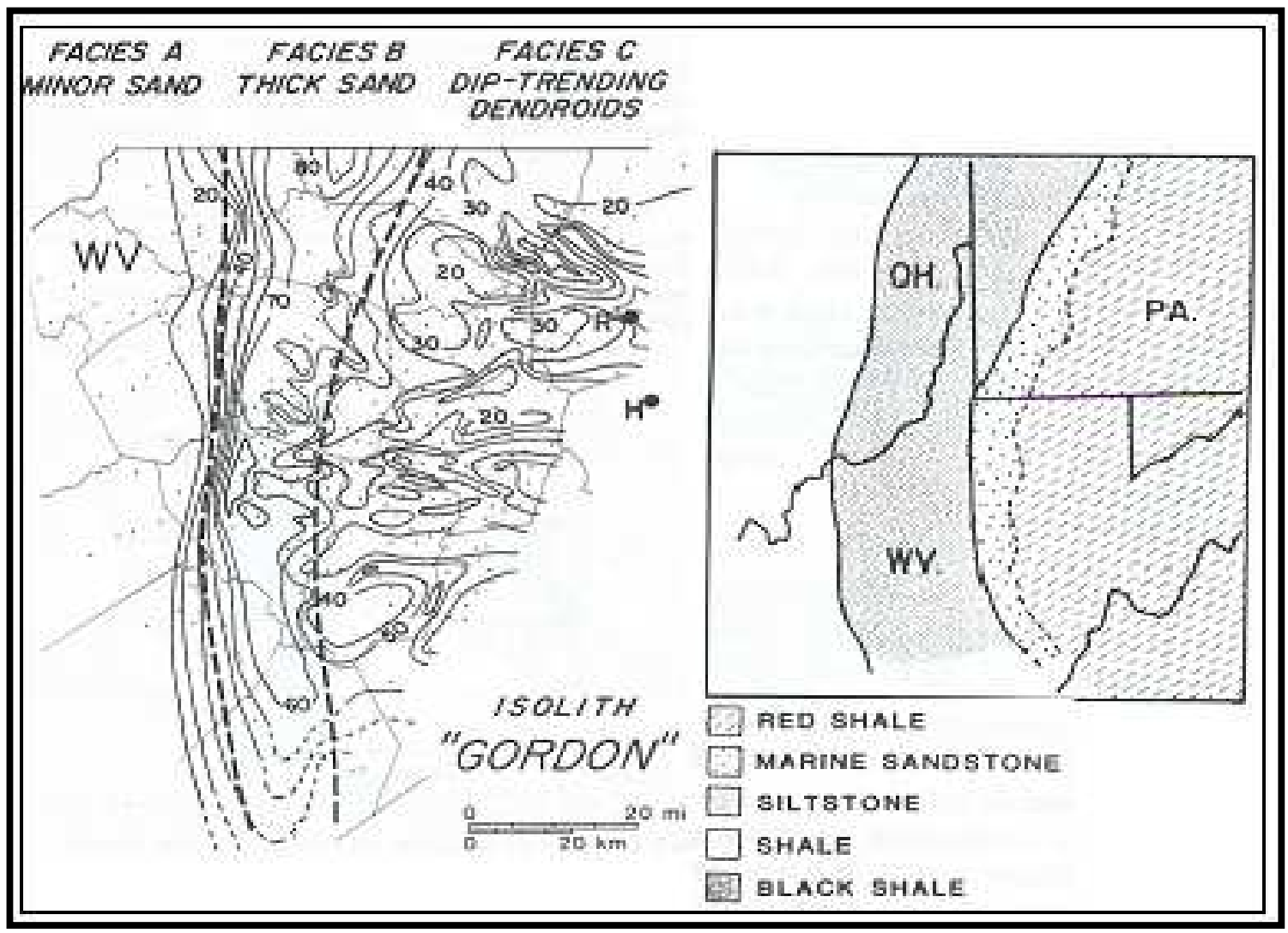

Figure 10. (Left) Isolith map of the Gordon zone during Late Famennian time in northern West Virginia. Facies $\mathrm{A}=$ Greenland Gap Formation, Facies $\mathrm{B}=$ Venango Formation, Facies C=Rowlesburg Formation (Right) Lithofacies map for Gordon zone. From Boswell and Donaldson 1988. 


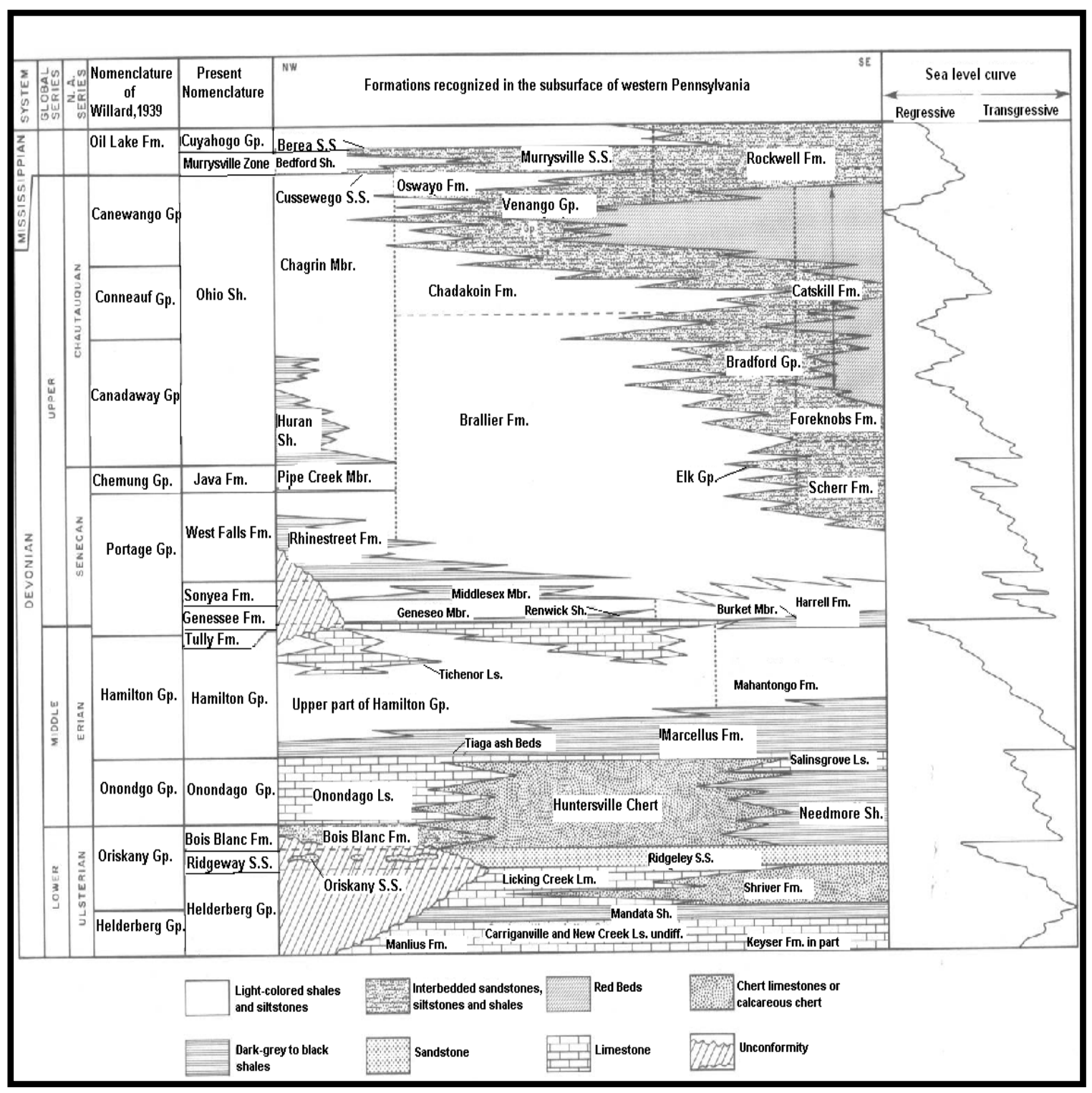

Figure 11. Devonian stratigraphic units in the subsurface of Pennsylvania. From Harper and Laughrey (1987). 
In southwestern Pennsylvania, Venango Group rocks consist of interbedded conglomerate, sandstone, siltstone, and shale. The sandstones can be divided into four to seven individual zones. The Gordon Stray and Gordon are two sandstone units that occur at the top of this zone (Harper and Laughrey, 1987).

The Gordon and Gordon Stray beds are locally persistent, though difficult to trace over large areas. Generally, the Gordon beds tend to be thicker and more laterally persistent; however in some areas the Gordon Stray exceeds the Gordon in thickness and lateral continuity. In other areas the two merge to form one unit with only a slight shale break. The sandstone varies in color from light gray, brown, pinkish to white, and it is typically fine to coarse-grained, occasionally containing conglomeratic lenses of flattened elliptical quartz pebbles up to one inch (Harper and Laughrey 1989).

A petrographic and sedimentologic study of Venango sandstones was carried out by Harper and Laughrey (1987) as part of a regional study of southwestern Pennsylvania fields. Detrital grains consist of quartz (67-95\%), feldspar (10\%), mica (10\%), and rock fragments. These authors distinguished three distinct sandstone lithofacies based on rock texture: (1) medium to coarse grained sandstone, very poorly sorted and conglomeritic, with a matrix ranging from 9 to 23 percent, (2) medium to very coarse grained sandstone and grain-supported conglomerate, (3) very fine grained and very well sorted sandstone with no matrix.

Six depositional facies were recognized by Harper and Laughrey (1987) in the Venango Group sandstones of southwestern Pennsylvania (Table 1). Facies 1 consists of a fining-upward sequence characterized by green to grey, fairly well sorted, fine-grained sublitharenite. Sandstones are 10 to $15 \mathrm{ft}$. in thickness and display a variety of 


\begin{tabular}{|c|c|c|c|c|c|c|c|c|}
\hline Facies & . & $\begin{array}{l}\text { Grain } \\
\text { Size }\end{array}$ & Sorting & Color & $\begin{array}{l}\text { Sandstone } \\
\text { thickness }\end{array}$ & Fossils & Structures & $\begin{array}{l}\text { Sequence } \\
\text { Stratigraphy }\end{array}$ \\
\hline 1 & Sandstone & $\begin{array}{l}\text { Fine } \\
\text { Grained }\end{array}$ & $\begin{array}{l}\text { Poorly to } \\
\text { very } \\
\text { Well }\end{array}$ & $\begin{array}{l}\text { Green } \\
\text { to } \\
\text { Grey }\end{array}$ & 10 to $15 \mathrm{ft}$ & $\mathrm{N} / \mathrm{A}$ & $\begin{array}{l}\text { Trough and } \\
\text { Planar } \\
\text { Cross- } \\
\text { Bedding } \\
\text { - Ripple } \\
\text { Bedding } \\
\text { Lag } \\
\text { Deposits }\end{array}$ & $\begin{array}{l}\text { Fining- } \\
\text { upwards } \\
\text { Sequenoe }\end{array}$ \\
\hline 2 & $\begin{array}{l}\text { Sandstone } \\
\text { and } \\
\text { Conglonerate }\end{array}$ & $\begin{array}{l}\text { Medium } \\
\text { to Fins }\end{array}$ & $\begin{array}{l}\text { Moderate } \\
\text { to Pcor }\end{array}$ & $\begin{array}{l}\text { Yetlow } \\
\text { to } \\
\text { Grey }\end{array}$ & 2 to $3 \mathrm{ft}$ & N/A & $\mathrm{N} / \mathrm{A}$ & $N / A$ \\
\hline 3 & Sandstone & Fin: & $\begin{array}{l}\text { Moderate } \\
\text { to Well }\end{array}$ & Grey & 6 to $8 \mathrm{ft}$ & $\begin{array}{l}\text { Plant } \\
\text { Fragments }\end{array}$ & $\begin{array}{l}\text { Cross- } \\
\text { Bedding } \\
\text { Current } \\
\text { Ripples } \\
\text { Clay } \\
\text { Pebbles }\end{array}$ & $\begin{array}{l}\text { Cosrsening } \\
\text { Upwards } \\
\text { Sequence }\end{array}$ \\
\hline 4 & $\begin{array}{l}\text { Sandstone } \\
\text { Interbedojed } \\
\text { with Sbale }\end{array}$ & Mediam & Moderate & $\begin{array}{l}\text { Light } \\
\text { Brown }\end{array}$ & $>1 \mathrm{ft}$ & $\begin{array}{l}\text { Bivalves- } \\
\text { Eoschizodius } \\
\text { and } \\
\text { Glossites } \\
\text { Hotizontal } \\
\text { Burrows }\end{array}$ & $\begin{array}{l}\text { Parallel } \\
\text { Laminations } \\
\text { Wavy } \\
\text { Bedâting } \\
\text { Symmetrical } \\
\text { Rupples }\end{array}$ & N/A \\
\hline 5 & $\begin{array}{c}\text { Sandstone } \\
;\end{array}$ & Medium & $\begin{array}{l}\text { Well } \\
\text { Sorted }\end{array}$ & $\begin{array}{l}\text { Brown } \\
\text { To } \\
\text { Grey }\end{array}$ & N/A & $\begin{array}{l}\text { Bivalve } \\
\text { Molds } \\
\text { Plant Debris } \\
\text { Horizontal } \\
\text { Burrows }\end{array}$ & $\begin{array}{l}\text { Parallel } \\
\text { Laminations } \\
\text { Symmetrical } \\
\text { Rupples }\end{array}$ & $\mathrm{N} / \mathrm{A}$ \\
\hline $6 A$ & $\begin{array}{l}\text { Sandstone } \\
\text { Silt and Shale }\end{array}$ & Medium & $\begin{array}{l}\text { Well to } \\
\text { Coarse }\end{array}$ & $\begin{array}{l}\text { Brown } \\
\text { To } \\
\text { Grey }\end{array}$ & $\mathrm{N} / \mathrm{A}$ & $\begin{array}{l}\text { Large } \\
\text { Burrows }\end{array}$ & $\begin{array}{l}\text { Symmetrical } \\
\text { Ripples } \\
\text { Horizontal } \\
\text { Laminations }\end{array}$ & $\begin{array}{l}\text { Coarsening } \\
\text { Upwards } \\
\text { Sequence }\end{array}$ \\
\hline $6 B$ & $\begin{array}{l}\text { Sacdstone } \\
\text { Conglomerate }\end{array}$ & $\begin{array}{l}\text { Modium } \\
\text { to } \\
\text { Coarse }\end{array}$ & $\begin{array}{l}\text { Well to } \\
\text { Coarse }\end{array}$ & $\begin{array}{l}\text { Brown } \\
\text { To } \\
\text { Grey }\end{array}$ & 6 to $18 \mathrm{In}$ & $\begin{array}{l}\text { Mollusk } \\
\text { Sbells }\end{array}$ & $\begin{array}{l}\text { Ripples } \\
\text {,Scour } \\
\text { Surface } \\
\text { Horizontal } \\
\text { Laminations } \\
\text { Tool Marks }\end{array}$ & $\begin{array}{l}\text { Fining } \\
\text { Upwards } \\
\text { Seçuesce }\end{array}$ \\
\hline
\end{tabular}

Table 1. Summary of the six Venango Group facies described by Harper and Laughrey (1987) 
sedimentary structures including trough and planar cross-bedding and ripple bedding. At the base of each fining-upward sequence is a scour surface with lag deposit. The depositional environment of facies 1 has been interpreted to be that of a sandy channel of a fluvial-dominated delta.

Facies 2 consists of yellowish grey, very poorly to moderately sorted, medium to coarse-grained, conglomeritic, feldspathic and lithic graywacke. Rocks in facies 2 appear as conglomerate interbedded with horizontally stratified conglomeritic sandstone and lenses of fine-grained sandstone. The average thickness is 2-3 feet. Sedimentary structures are absent. The depositional environment of facies 2 is interpreted as that of a conglomeritic channel of the fluvial deltaic environments.

Facies 3 sandstone is grey, moderately well sorted, fine-grained, coarseningupward quartzarenite and quartzwacke. Sedimentary structures include cross-bedding and current ripples, with large amounts of clay pebbles and plant fragments. Facies 3 sandstone typically displays tabular to sheet geometries with a thickness of 6 to 8 feet. The depositional environment has been interpreted as a distributary mouth-bar

Facies 4 consists of thinly bedded, light brown, medium-grained, moderately sorted subarkose. This sandstone contains quartz pebbles and a high concentration of mica. Structures include horizontal burrows, parallel lamination, wavy bedding, and symmetrical ripple marks along with bivalve fossil molds representing both Eoschizodus and Glossites. Sandstone thickness is less than $1 \mathrm{ft}$., and beds are typically interbedded with shale. Facies 4 has been interpreted to represent a tidal-flat environment.

Facies 5 sandstone is brown to grey, well sorted, medium-grained, quartzarenite. Lenses of quartz granule-pebbles are present within facies 5. Sedimentary structures 
include subhorizontal to horizontal parallel lamination and symmetrical ripple bedding. Small amounts of plant debris and bivalve molds can be observed, along with horizontal burrows in the upper portion of the sandstone beds. Facies 5 has been interpreted as being deposited in a foreshore setting which was part of the delta front sheet sandstone adjacent to the distributary channel complex.

Facies 6 is brown to gray, medium to coarse-grained sublitharenite, which displays coarsening and fining-upwards sequences. Coarsening-upward sequences (6A) are lenticular to tabular, medium-grained sandstone with large burrows at the top. Sandstones are encased in medium gray shale and siltstone, and display symmetrical ripples. Internal bedding is characterized by subhorizontal lamination. The fining-upward sequences (6B) consist of graded, multiple-stacked tabular beds, with a basal scour surface and undulatory ripple marks. Thickness of these sequences range from 6 to 18 inches. Above the scour surface lies a thick quartz-rich pebble conglomerate, which grades upward into horizontally laminated sandstones. Tool marks can be observed on the base of the beds, and broken clay-filled fossil mollusk shells occur in the conglomeratic lag. Deposition of facies 6 has been interpreted to have occurred in a shoreface environment.

The coarsening-upward sequences of facies 6 are thought to have formed as offshore bars on a muddy shoreface. The fining-upwards sequences of facies 6 are thought to have formed as turbidites. Turbidites are commonly associated with deep water basin; however as Harper and Laughrey (1987) pointed out, turbidites can occur in many environments including the delta front. The fining-upwards sequences of facies 6 are thought to have formed in a shallow-water environment. Turbidity currents are 
thought to have been generated by storm surges.

In northern West Virginia, McBride and Smosna (2005) described the Gordon Stray beds as a northeast trending barrier-island complex (Fig 12). The Gordon Stray consists of marine strata, 12-38 ft thick, which represent a major progradation of the shoreline. Thin packages of sandstone and shale within the unit reflect fourth and fifth order oscillations of relative sea level (McBride and Smosna 2005). The Gordon zone, which contains between two and six separate sandstone units, represents the westward most progradation of the Catskill delta, and the Gordon Stray represents the uppermost sandstone of this zone (Fig. 13).

Facies of the Gordon Stray have been interpreted by McBride and Smosna (2005) as lower and upper shoreface and foreshore of a barrier island complex. Contacts between each facies are gradational, with rocks displaying an overall coarsening-upwards sequence. The sandstones are well sorted and well rounded, conglomeratic with a sandy matrix. The lower shoreface is described as fine-grained, the upper shoreface is mainly medium-grained, and the foreshore is mainly medium-grained to conglomeritic (Fig 14). Interbeds of shale, displaying lenticular bedding and laminated structures, decrease upsection. Thin pebble beds, mud clasts, and lithic grains are scattered throughout the sandstone; however, their occurrence increases up-section. Structures include scour and fill, trough cross-bedding, large-scale cross-bedding and horizontal lamination. Although sparse, brachiopod shells are present in all three facies, and vertical burrows have been observed in some of the shale and fine sandstone (McBride and Smosna 2005). 


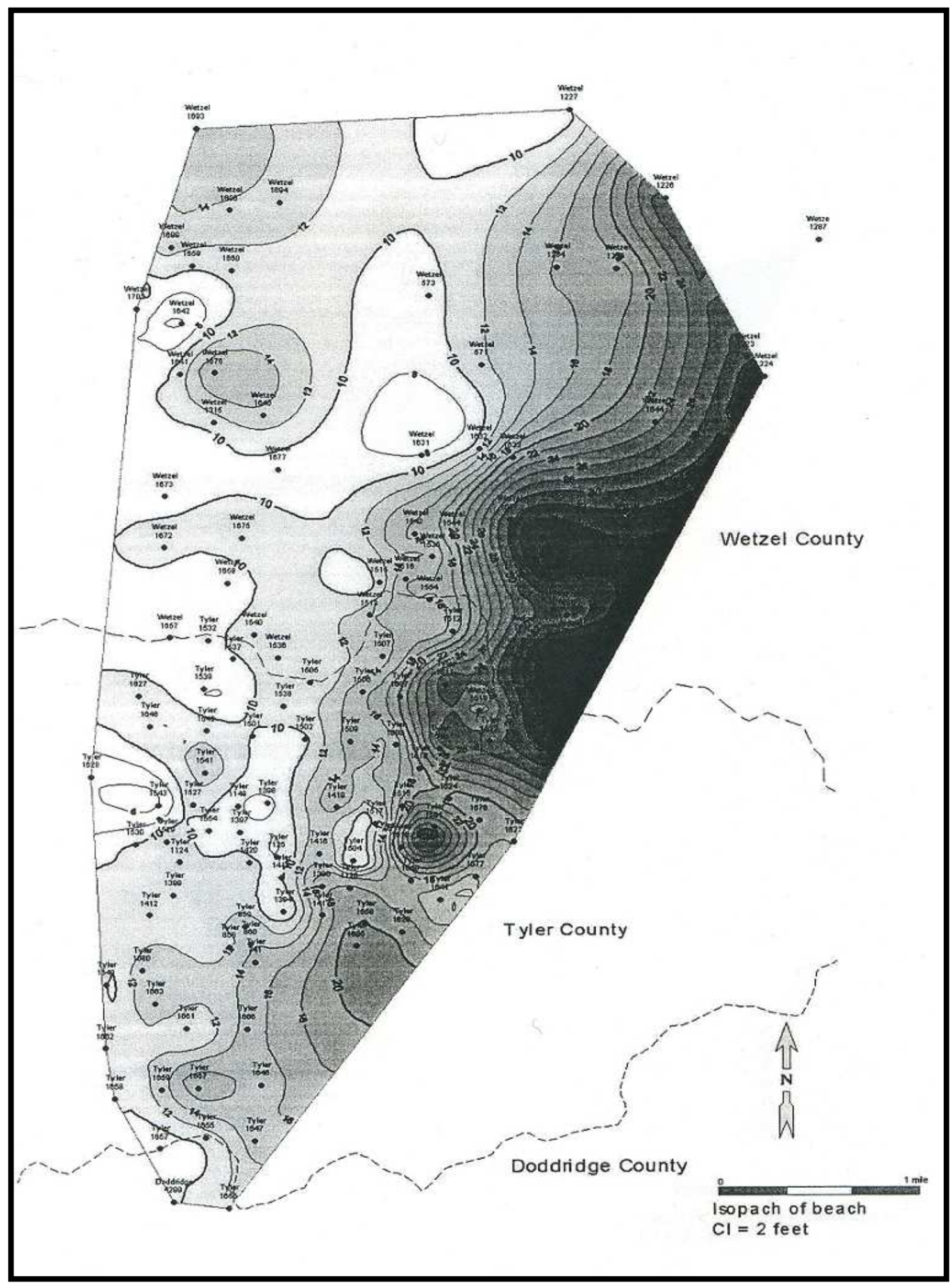

Figure 12. Isopach map of Gordon Stray beds in northern West Virginia showing a barrier bar to the east. Modified from McBride and Smosna (2005) 


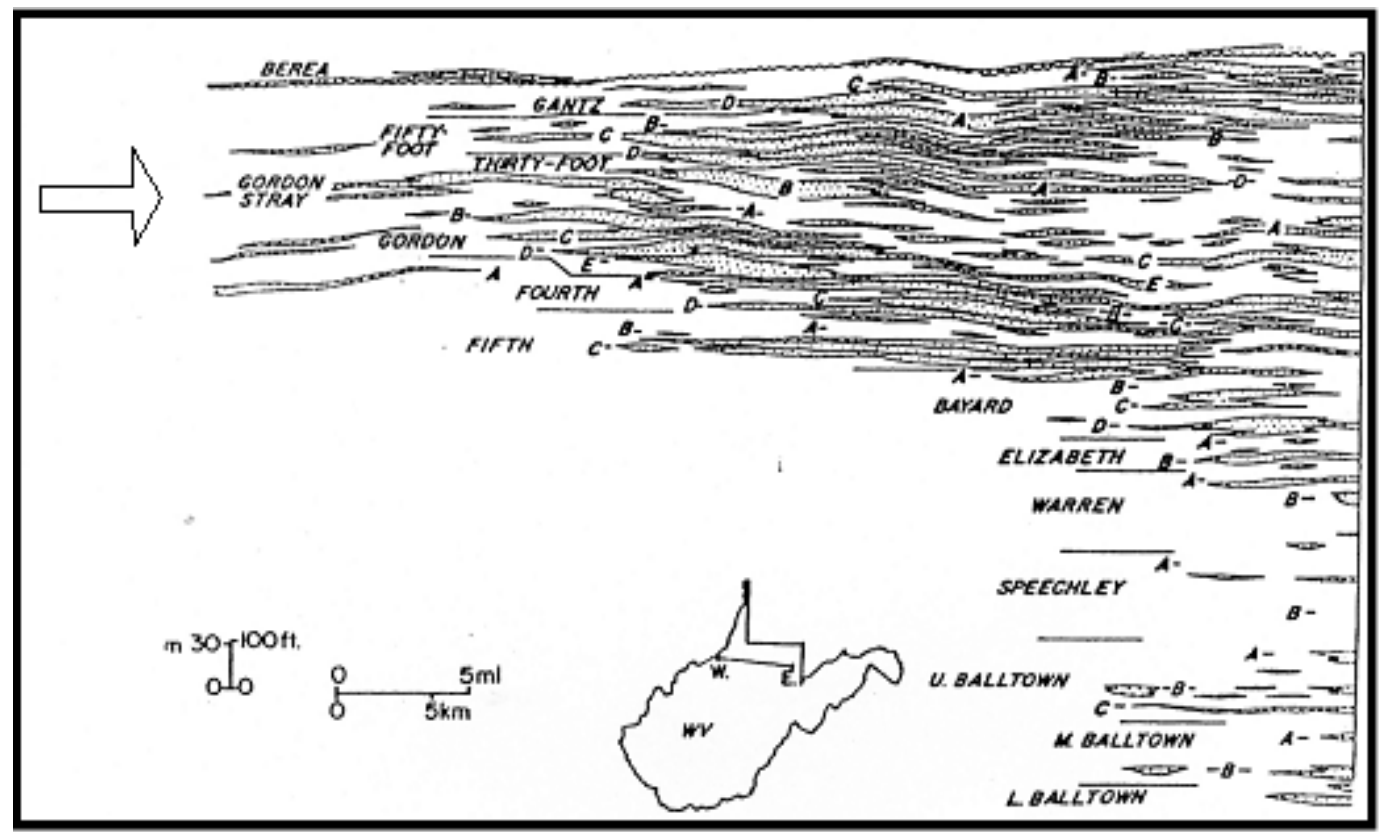

Figure 13. Cross-section showing the distribution of informal sandstone zones in the Upper Devonian of West Virginia. The Gordon Stray sandstone is located near the top of the Venango Formation. From Boswell and Jewell (1988).

A

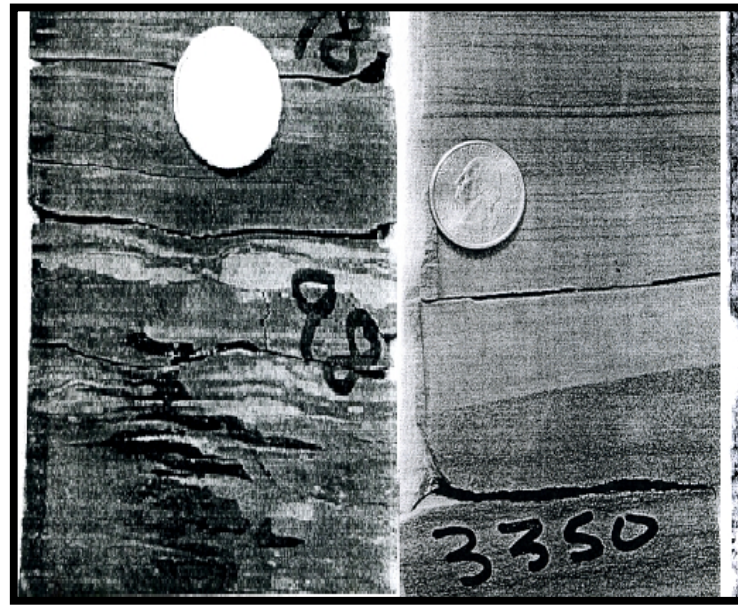

$\mathrm{C}$

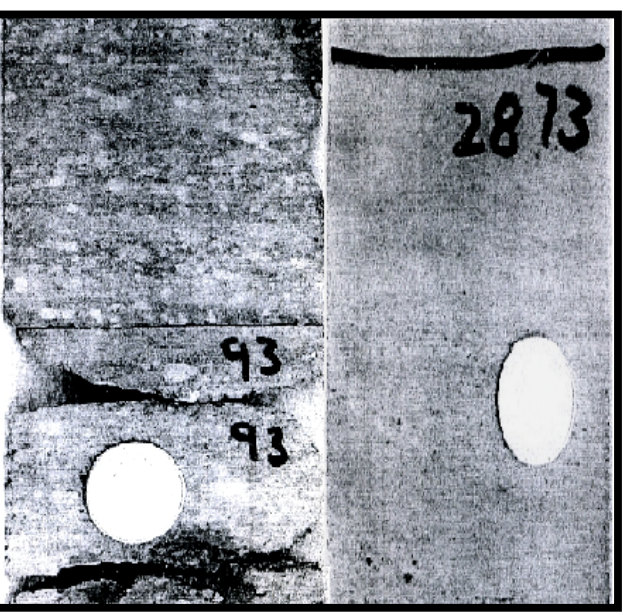

Figure 14. Cores of the Gordon Stray. $A=$ shale of the inner shelf with sand ripples and small sand filled horizontal burrows, $\mathrm{B}=$ fine-grained sandstone of the lower-shoreface with horizontal laminations. $\mathrm{C}=$ inter-bedded conglomerate and medium-grained sandstone of the foreshore with horizontal stratification, $\mathrm{D}=$ medium to very coarse-grained sandstone of the upper-shoreface displaying large-scale planar cross-bedding. Modified from McBride and Smosna (2005). 
From a reservoir characterization study in the Jacksonburg-Stringtown oil field in northern West Virginia, Ameri et. al. (2001) described the Gordon Stray beds. Although the depositional environment was not interpreted in that study, the lithology and stratigraphy were described from a core and well-log analysis. Five lithofacies were described for the Gordon Stray and they include, 1 featureless sandstone, 2 laminated sandstone, 3 conglomeritic sandstone, 4 shale, and 5 heterolithic bioturbated lithofacies (Ameri et. al, 2001) (Fig 15)

Shale of lithofacies 1 is described as dark gray, laminated, and commonly bioturbated. In some samples, siderite is observed. The thickest shale beds are found in the lower part of the Gordon Stray. In core samples, this lower shale is not present and can only be described from well logs in this study. Higher in the Gordon Stray beds, thin shale is interbedded with sandstone. Featureless lithofacies 2 is described as fine to very fine, well sorted sandstone with few sedimentary structures. In some cases horizontal laminations and scattered quartz pebbles can be observed (Ameri et. al, 2001).

Laminated sandstone of lithofacies 3 is described as fine to very fine-grained and very well sorted with a large variety of sedimentary structures, including horizontal laminations and low-angle cross-bedding. Cross-bedding is bidirectional. Occasionally, quartz pebbles layers can be observed. Bioturbation is rare; however where observed, burrows appear as large single burrows. Root traces have been observed but are also rare, and body fossils include brachiopods, bivalves, and echinoderm fossil fragments (Ameri et. al, 2001).

Conglomeritic sandstone of lithofacies 4 has a bimodal distribution of grain sizes, with pebble-sized clasts and fine-to very fine-grained sandstone. The texture ranges from 
A $\quad$ B $\quad$ C

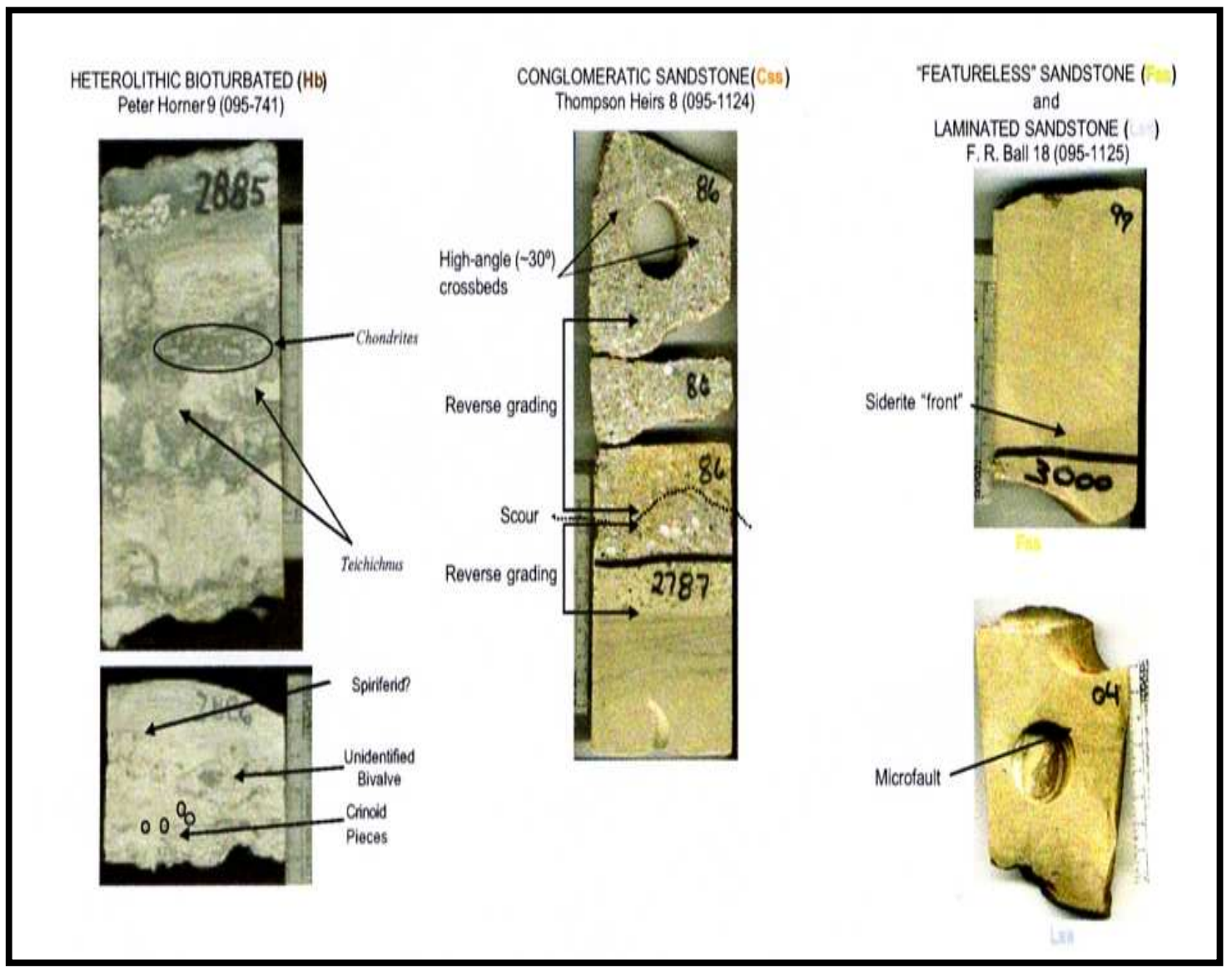

Figure 15. Cores of the Gordon Stray, $A=$ Heterolithic bioturbated lithofacies, $B=$ conglomerate sandstone lithofacies, $\mathrm{C}=$ featureless sandstone lithofacies. From Ameri et.al (2001) 
matrix-supported to clast-supported. Many of the conglomeritic beds appear to be lag deposits deposited upon a scour surface. Sedimentary structures within the conglomeritic beds include low-angle, bi-directional cross-bedding, high-angle (up to 45 degrees) crossbedding, reverse grading, rare ripple beds, shale rip-up clasts, and rare fossils including orthocone cephalopods (Ameri et. al, 2001).

The heterolithic bioturbated lithofacies (5) is present at the top of the Gordon Stray beds, and is described as highly bioturbated, interbedded sandstone and shale. Trace fossils are the most common fossils in this lithofacies, and they include Chondrites sp. and Teichichnus sp.. Other fossils observed include brachiopods, bivalves, and crinoids fossil fragments. Sedimentary structures include ripple cross-beds within the sandstones (Ameri et. al, 2001).

Primary differences in the laminated sandstone facies 2, and the featureless sandstone facies 1 , can be seen in both core and on well log. In core, laminated sandstone lithofacies appear denser than the featureless sandstone. The density of the laminated sandstone is around $2.5 \mathrm{~g} / \mathrm{cm}^{3}$, while the density of the featureless sandstone is around $2.3 \mathrm{~g} / \mathrm{cm}^{3}$. This density difference is attributed to higher porosity within the featureless sandstone lithofacies. The featureless sandstone is in fact the primary reservoir within the field. The Gordon Stray has permeabilities that range from 100 millidarcies $(\mathrm{mD})$ to less than $25 \mathrm{mD}$.

Boswell et al. (1987) also described the Gordon zone in northern West Virginia utilizing gamma-ray well logs. From these logs, the Gordon zone is determined to be a thick sequence of clean amalgamated shoreline sandstone that occurs as a narrow belt trending north-south in the central part of West Virginia (Fig 16). 


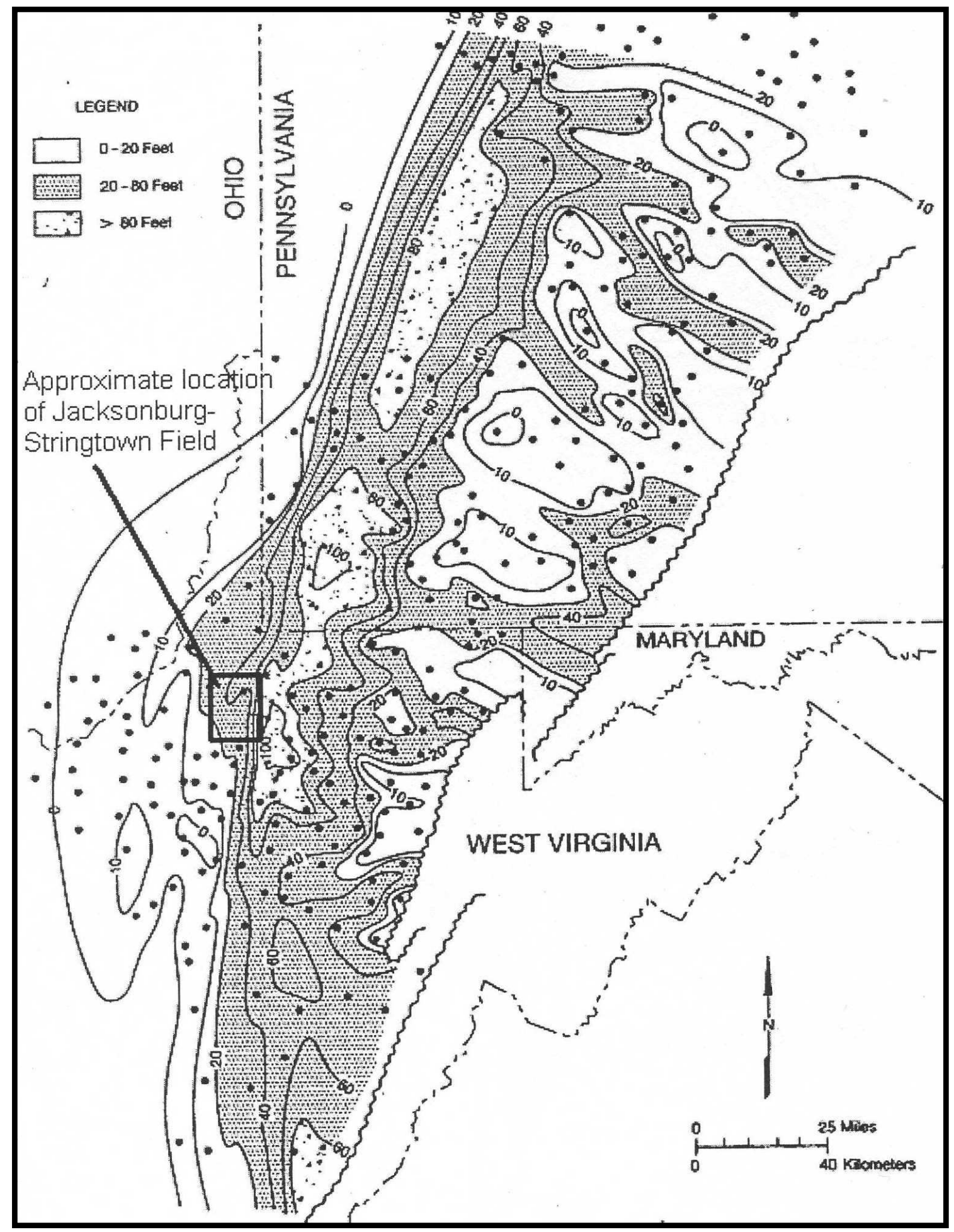

Figure 16. Thickness of Gordon Zone in West Virginia and Pennsylvania. From Boswell et al, (1996). 
At the top of the Gordon zone lies the Gordon Stray, a thin tongue of sandstone that prograded as much as 18 miles westward of the Gordon beds in Wetzel and Marshall counties, West Virginia (Boswell et al.1987). The Gordon zone transitions westward into shale and siltstone units of the upper Greenland Gap Formation, and eastward into the red mudstones of the Rowlesburg Formation (Fig 17). Regional trends, geometry and depositional environment of the Gordon zone have been presented by Boswell and Jewell (1988) for northern and southeastern West Virginia. The sandstone distribution pattern for the Gordon zone has been described as S2 type shoreline sandstone that trends along strike of the paleoslope. This is an indication of progradation of the Catskill shoreline during late Famennian times (Fig. 18).

According to Boswell et al. (1987), shifting Catskill shorelines were increasingly affected by eustacy, as well as growth faults, climate change, river avulsion and episodic tectonism. As they noted, by Gordon time shorelines gradually became straight, which suggests stability of the shoreline and still-stand conditions. The Gordon Stray beds lie above and westward of the primary Gordon trend and mimic the overall sandstone distribution of the Gordon beds below it (Fig.19). This westward offset of the Gordon Stray suggests a forced regression during time of deposition (McBride and Smosna 2005).

Hopkins (1992) investigated Venango outcrops in Warren and McKean counties, Pennsylvania, and Cattaraugus and Chautauqua counties, New York, where the unit is divided into three distinct sandy zones, namely Upper, Middle, and Lower. The Upper Venango consists of burrowed, conglomeritic sandstone, overlain by shale and 


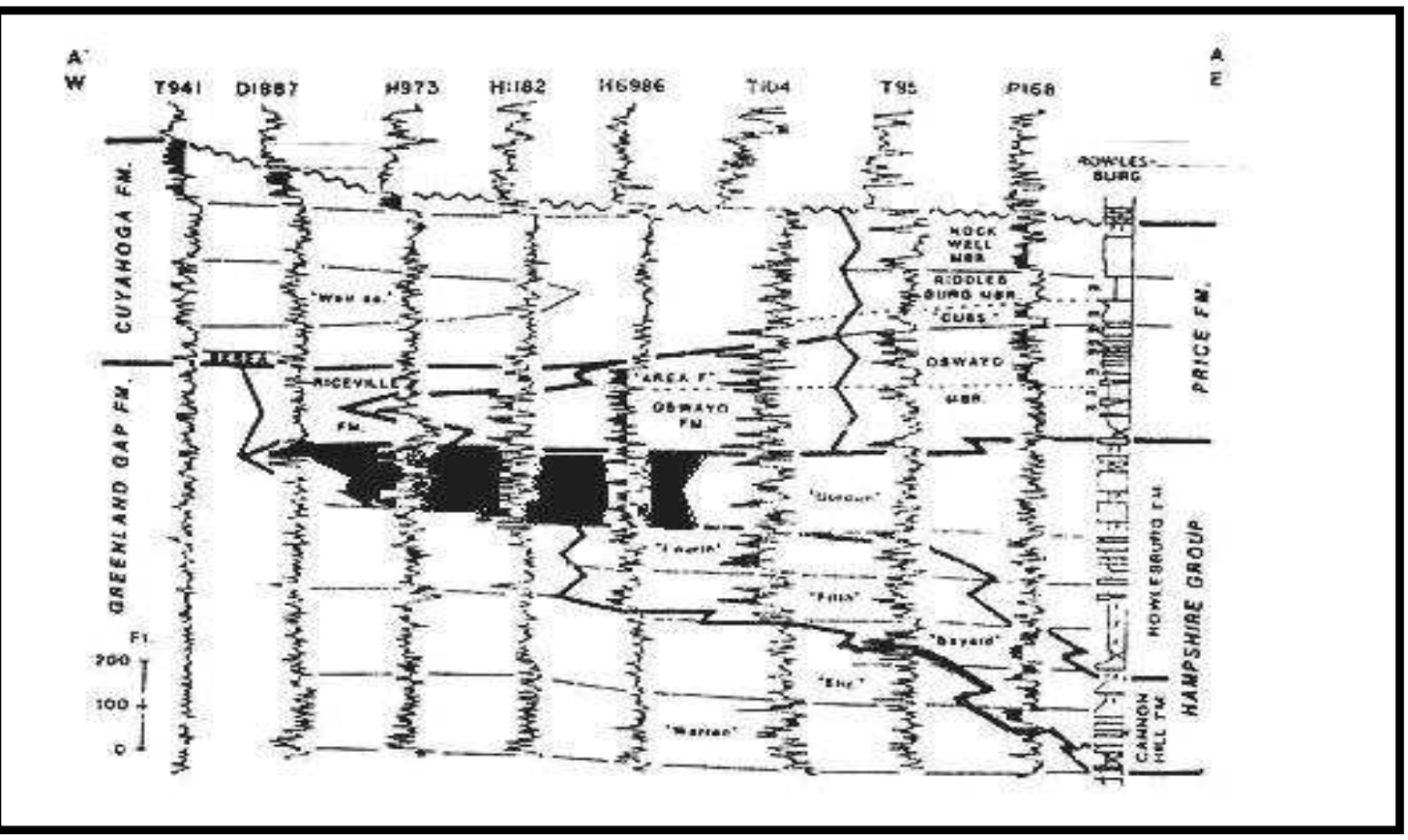

Figure 17. East-West gamma-ray cross-section illustrating the subsurface stratigraphy of northern West Virginia, and correlation to outcrops in Rowlesburg, Preston, County West Virginia. The Venango Formation is shaded black. Boswell and Jewell (1988).

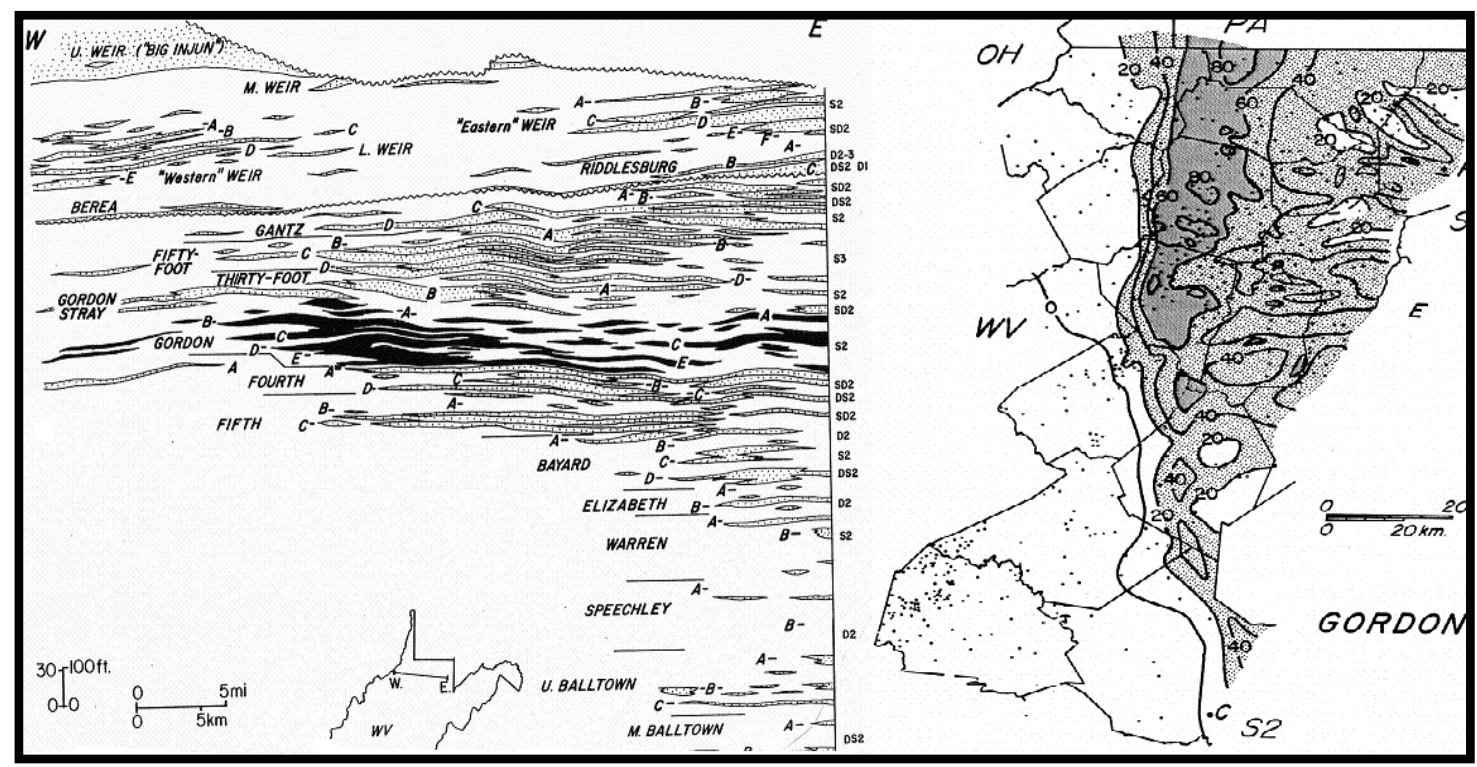

Figure 18. (left) Stratigraphic position of upper Devonian sandstone units in northern West Virginia. Gordon sandstone and upper Gordon Stray (in black) can be observed near the middle of the illustration. (Right) Isopach map of the Gordon zone displaying S2 configuration. From Boswell et al. (1987). 


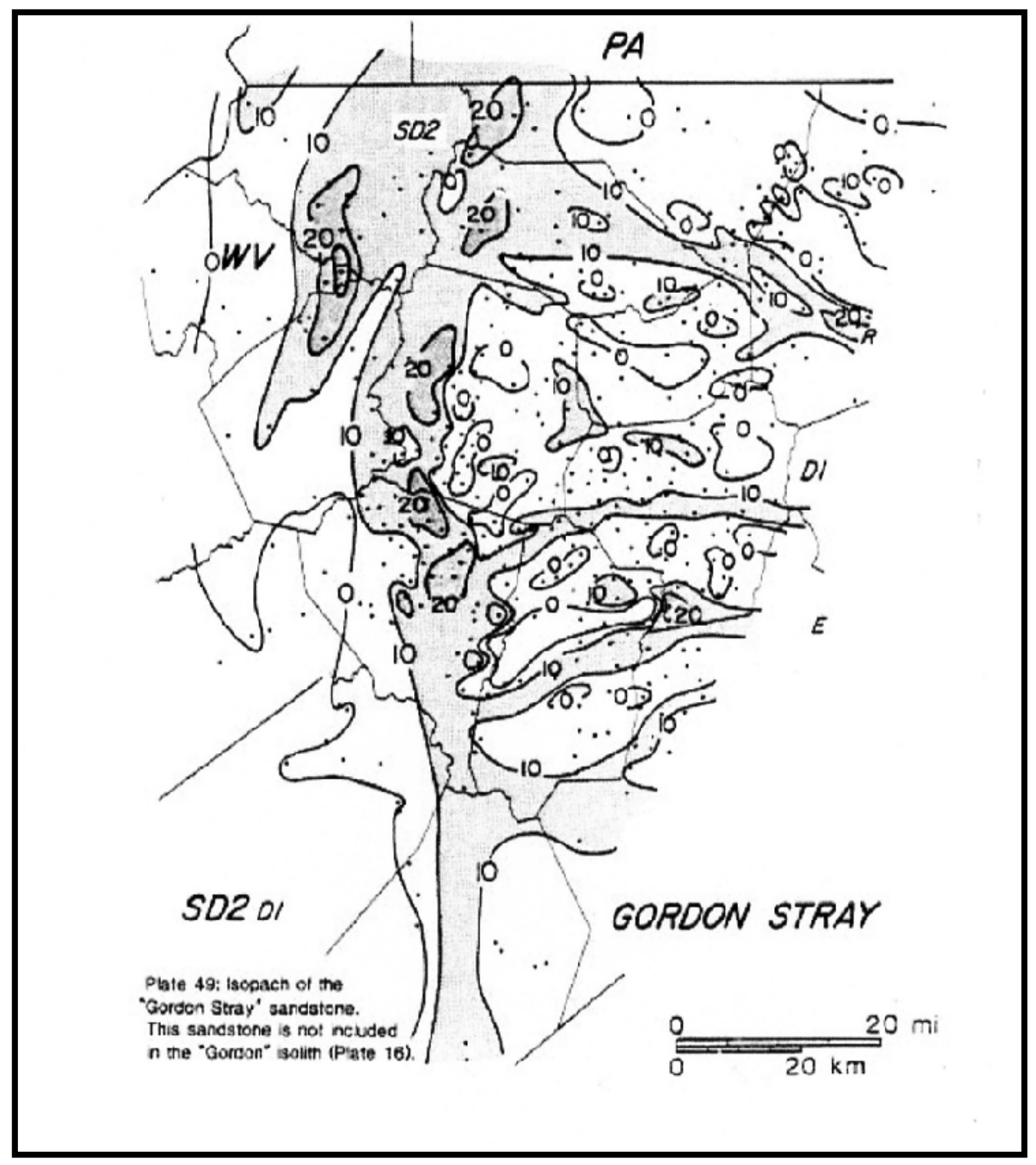

Figure 19. Isopach map showing Gordon Stray sandstone thickness and distribution in northern West Virginia. From Boswell, et al. (1987). 
distributary-mouth-bar, delta-platform sandstone with tidal-inlet conglomerates, and the lower zone is described as tidal-inlet conglomerates, barrier/backbarrier intertidal, and shelf sandstone and shale (Hopkins 1992).

At an outcrop on the Fayette-Somerset county line, southwestern Pennsylvania, Harper and Laughrey (1989) described the Venango Group in detail. The lower sandy zone consists of fine to coarse-grained, locally conglomeratic, poorly to well sorted sandstone. Compositionally, the sandstone consists of feldspathic and lithic greywacke, sublitharenite, and quartzarenite. The source area was an uplifted sedimentary and metasedimentary tectonic terrain (Acadian mountains). Sand was transported to the northwest by a fluvial system and deposited in a number of paralic-deltaic environments that shifted in response to relative sea-level change. In general, the lower sandy zone is thought to have originated as a transgressive coastal sequence (Harper and Laughrey 1989).

Time equivalent to the marginal-marine sandstone of the Gordon, the middle red shale zone has been described by Harper and Laughrey (1989) to be part of the Hampshire tongue. Rocks from this zone consists of approximately 100 feet of stacked, fining-upward cycles dominated by fine-grained rock types in the lower half and by sandstone and siltstone in the upper half. The sandstone is reddish gray, fine-grained, moderately sorted, micaceous, and sublithic to lithic in nature. A variety of sedimentary structures includes trough cross-bedding, tabular cross-stratification, low-angle to planar bedding and lamination, and current-ripple lamination. Scour surfaces on the base of individual fining-upward sequences are common, and sandstone generally exhibits channel geometry. Plant fossils are abundant. Sandstone bar forms with calcite cement 
and coarse carbonate grains interfinger with the more common sandstone described above. Shale and siltstone are red and contain burrow traces and green mottling. As described by Harper and Laughrey (1989), the middle zone resembles delta-plain and alluvial-plain nonmarine facies of the Catskill coastal plain.

The upper sandy zone consists of an assortment of marine, marginal marine and non-marine rocks. At the base of the upper sandy zone, rocks are fluvial in origin. Rocks consist of fine to very fine-grained, sublitharenites, litharenites, siltstone, and shale. Sandstone contains cross-bedding and climbing ripple laminations. Within the ripple laminations, plant debris is abundant. Coarser-grained sandstone with tabular crossbedding overlays the ripple-bed sequence. At the base of this interval, rip-up clasts and discontinuities are present. The fluvial sequence fines upwards into siltstone with lenses of fine sandstone. The rocks that make up this lower sequence in the upper sandy zone are thought to represent the top of a point-bar sequence (Harper and Laughrey 1989).

Above this unit, rocks consist of lenticular, wavy, and flaser bedded sandstone, siltstone, and shale. Sandstone in this unit contains both brachiopod body fossils and trace fossils. Interbedded with these rocks, coarser fining-upwards sandstones occur. Rhynchonellid brachiopods (Ptychomaletoechia) can be observed within some of these sandstones. Deposition of this unit is thought to be estuarine in origin. Estuaries generally form due to the transgression of former river valleys. Sedimentation takes place by means of both accretion and channel migration. In this unit, cross-bedded and laminated sandstones represent the high-energy banks of the estuary channel, whereas the lithologies that contain wavy, flaser, and lenticular bioturbated rocks represent the lowerenergy banks of the channel (Harper and Laughrey 1989). 
Above this unit, rocks consist of interbedded sandstone, siltstone, and shale. Three distinct facies can be observed including tidal flat, channel, and shoal deposits. The tidal-channel facies are represented by fining-upwards sandstone bodies with minor shale layers that contain scour surfaces, fossil lags, current and wave ripples, slump structures, and load casts. The tidal flat and shoal facies are represented by lenticular, flaser, and wavy bedding. Biological activity is noted by the presence of marine fossils, trace fossils, bioturbation, and plant debris. At the base of the lenticular sandstone, phosphatic pebble lags occur. This is evidence of current and wave reworking of the sediment.

At the top of the upper sandy zone, facies consists of dark grey to black shale. Inarticulate brachiopods, namely Lingula and fragments of cephlapods (Spyroceras) were observed in the shale. Based on isopach maps, the shale of this interval is flanked by sandstone shoals to the west (Harper and Laughrey 1989). The depositional environment of the shale has been interpreted by Harper and Laughrey (1989) to be that of a restrictedbay environment. Within the thicker shale sequences, negligible sandstone and siltstone beds occur. Within these beds, scour surfaces, along with vertebrate fossil lag, wave ripples, planer laminations, and hummocky laminations occur. These thinner coarser beds have been interpreted to have been deposited during storm events where energy was high enough to transport the coarser material into the bay (Harper and Laughrey 1989).

McCallister et.al. (2001) studied the Gordon Stray beds in the Donegal Storage Field of southwestern Pennsylvania. The depositional environment of the Venango Group sandstones there was interpreted to be fluvial deltaic in origin, and the Gordon Stray beds consist of at least two stacked channels (Fig. 20). The upper channel strikes N25E, and the lower channel strikes N30E. 


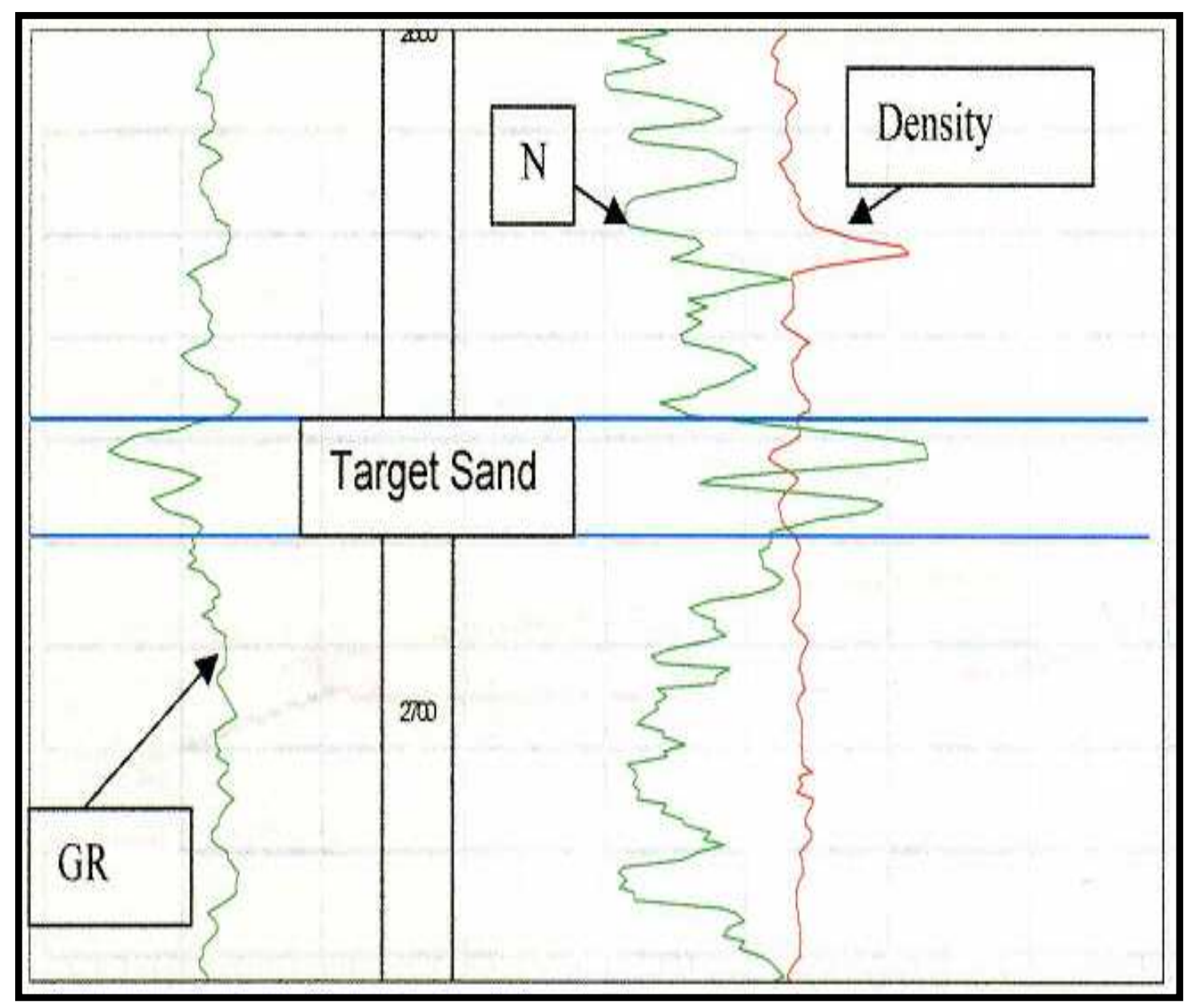

Figure 20. Typical well log in the Donegal storage field of southwestern Pennsylvania. Gordon Stray (target sandstone) occurs at approximately $2650 \mathrm{ft}$. From McCallister et al. (2001). Two stacked channels are evident from both gamma-ray and density curves. 
The Gordon Stray beds average 9 feet in thickness and occur at an average subsea depth of -1400 feet within the Donegal field (McCallister et al. 2001). Regionally, the Gordon Stray has an areal extent of 18,377 acres, and lateral variations of sandstone quality within the field are primarily due to facies changes related to sandstone-channel geometry. Within the field, the lithology of the Gordon Stray varies from fine to coarsegrained sandstone to siltstone and conglomerate. Permeability of Gordon Stray sandstone has been tested from 62 wells and ranges from 0.17 to $115 \mathrm{mD}$. (McCallister et al. 2001). 


\section{RESULTS}

\section{Geological Structures}

The structure map represents sub-sea elevation on top of the Gordon Stray beds (Fig. 21). The map is shaded darker to indicate structural low areas and lighter to indicate structural high areas in the study area. Structures on top of the Gordon Stray beds include a structural high in the far western part of the study area in Wetzel County. This feature is the New Martinsville anticline. To the east of this fold is a structural low that strikes approximately N60E through central Wetzel County, West Virginia. The orientation changes through Greene County, Pennsylvania, striking N20E. This feature is the Nineveh syncline. To the east lies a second structural high which is the Littleton anticline. To the east of the Littleton anticline however, the Gordon Stray structures do not closely match the surface (Pennsylvanian) structures (WVGS 1982), especially in this part of the study area where data control is poor. 


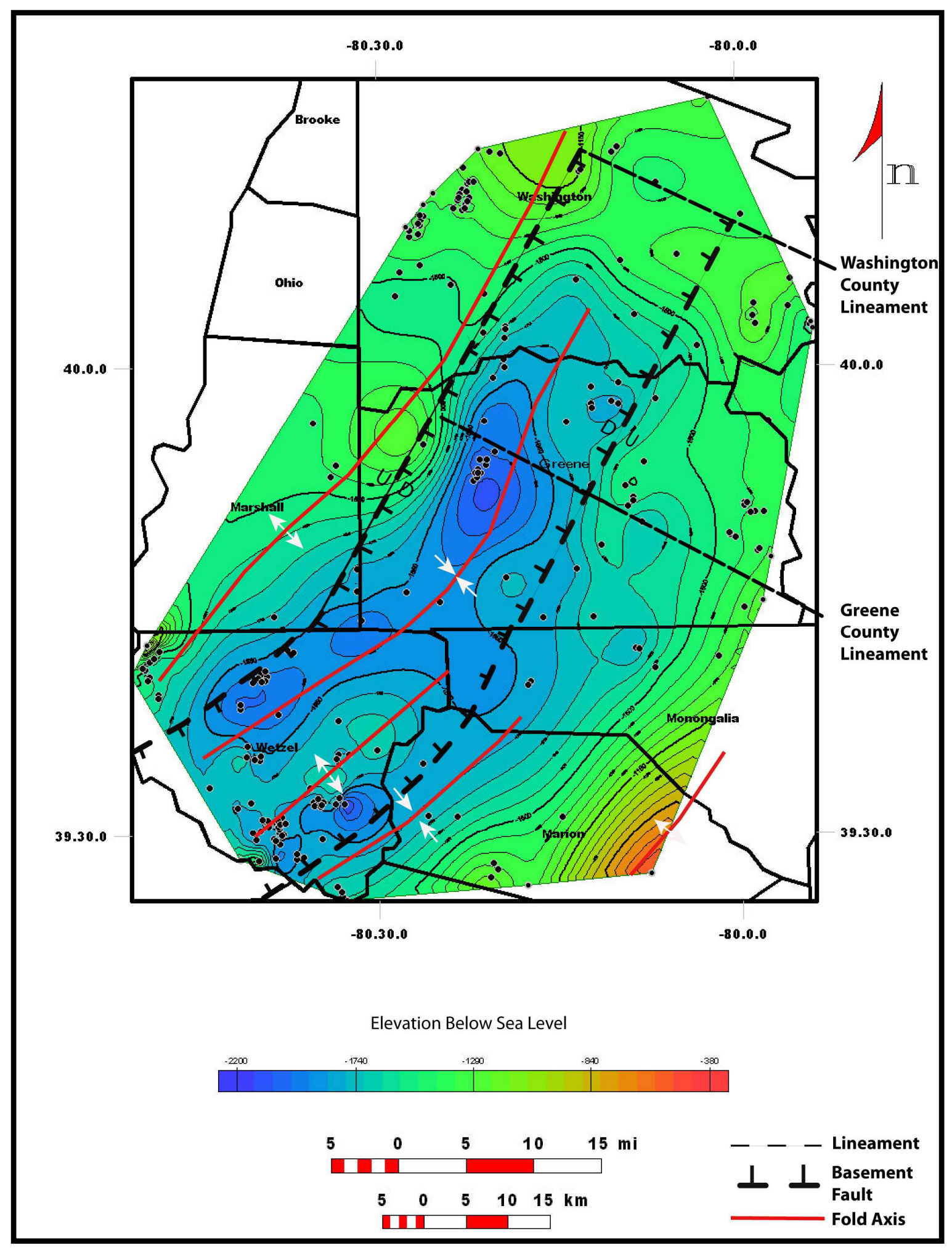

Figure 21. Structure map on top of the Gordon Stray beds with approximate locations of suspected basement faults from Wagner (1977) and lineaments from Flaherty (1996). 
The Gordon Stray structure map suggests a structural low to the east of the Littleton anticline which may be associated with the Burchfield syncline, and a structural high which could be associated with the Wolf Summit anticline.

Also included on the structure map is the approximate position of two basement faults in Pennsylvania from Wagner (1976). The faults continue SW into West Virginia and into Kentucky (Fig. 21). These basement faults are thought to be associated with the Rome Trough, a northeast-trending graben that is part of an extensive interior rift system that developed during Cambrian and Ordovician time (Gao et al. 2000). The position of the Nineveh syncline along the down-thrown side of the western fault suggests reactivation in the late Paleozoic (Flaherty 1996). In addition to the northeast-trending graben, there are cross-strike lineaments such as the Greene and Washington County lineaments in Pennsylvania (Flaherty 1996). Cross-strike lineaments may be associated with wrench faulting within the basement or within detached zones within Paleozoic strata (Flaherty 1996).

Gao et al (2000) divided the Rome trough into three depositional segments in Kentucky and West Virginia based on magnetic and gravity maps that indicate along-axis variations in depth and thickness of Paleozoc rocks. These variations mark the boundaries between additional major basement lineaments, namely the 38th parallel lineament and the Burning-Mann lineament (Fig 22). The present study is located within the northern half of the northern West Virginia segment. The extent of the Rome Trough to the north is generally unknown because of lack of published subsurface data in Pennsylvania. 


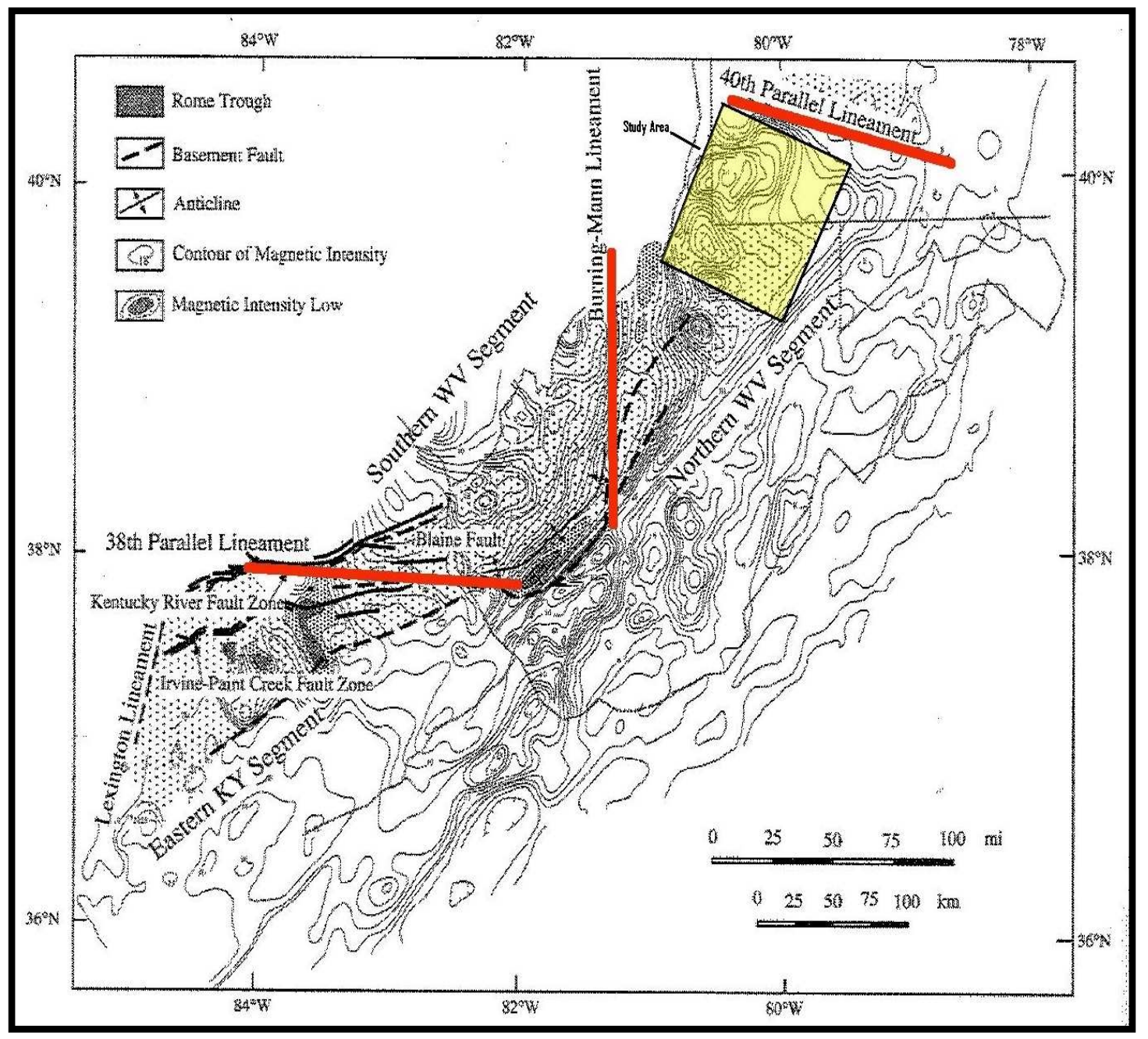

Figure 22. Tectonic and magnetic map showing positions of major lineaments and their associated depositional segments in West Virginia as they relate to the Rome Trough. The study area for this thesis is highlighted in yellow whereas major lineaments are colored red. Modified from Gao et. al (2000). 


\section{Gordon Beds}

By comparing gamma-ray well-log signatures from previous works, including Boswell et al. (1996), McCallister et al. (2001), and McBride and Smosna (2005), and the well-log signature from the studied core, the Gordon zone was identified and mapped in the study area. Stratigraphic picks for the top and bottom of the Gordon and Gordon Stray beds were based on a cut-off value of 100 API units where any value 100 API or greater represented gross thickness. Once tops and bottoms were picked for all wells, isopach maps were constructed using Geographix. In addition to isopach maps, four east-west and one north-south gross-cross-sections were created across the field to aid in the analysis (Figs. 23-29). Net-sandstone maps were also constructed using a maximum value of 80 API units to capture only the sandstone representative of the Gordon zone.

The isopach map of the Gordon beds shows one main trend with four local thicks, striking approximately N20E through Marion, Monongalia, Greene, and Washington Counties (Fig. 30). Length of the main trend is roughly 50 miles, whereas its width is variable. To the south, the trend is broad and averages approximately 20 miles. The trend narrows towards the center of the study area where the average width is 8 miles, and in the north the width increases again to approximately 15 miles. Thickness of the main trend is up to $80 \mathrm{ft}$. To the west of the western edge of the main isopach thick, several small pod-like bodies are present in Wetzel, Greene, and Washington Counties. These pods range from 25-40 feet thick. To the east of the main isopach thick, there are several wedge-like features in Marion, Greene, and Washington Counties. These thin to the east. 


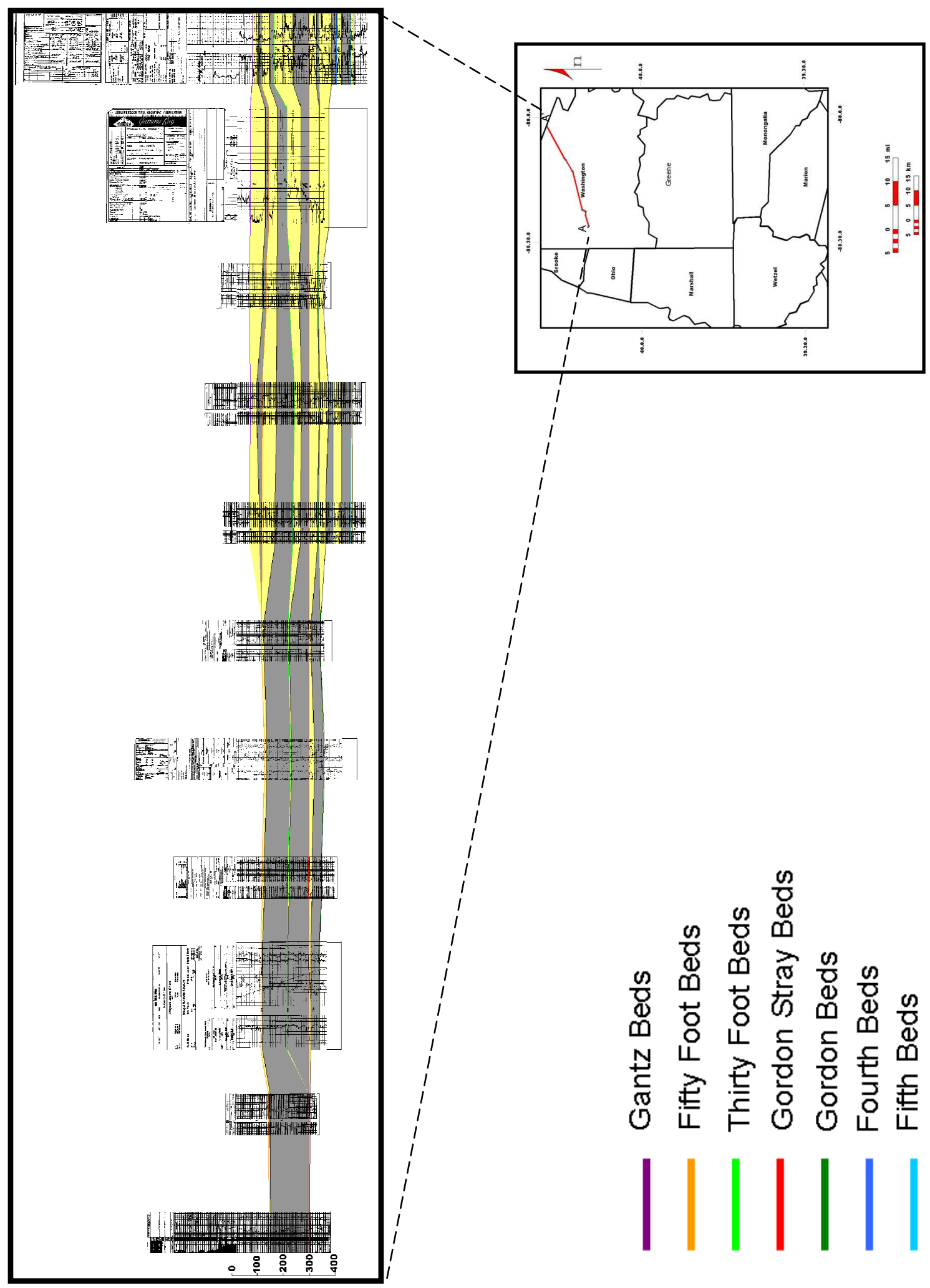

Figure 23. Gross cross-section A-A' showing the distribution of Upper Devonian beds including the Gordon and Gordon Stray across northern Washington County. 


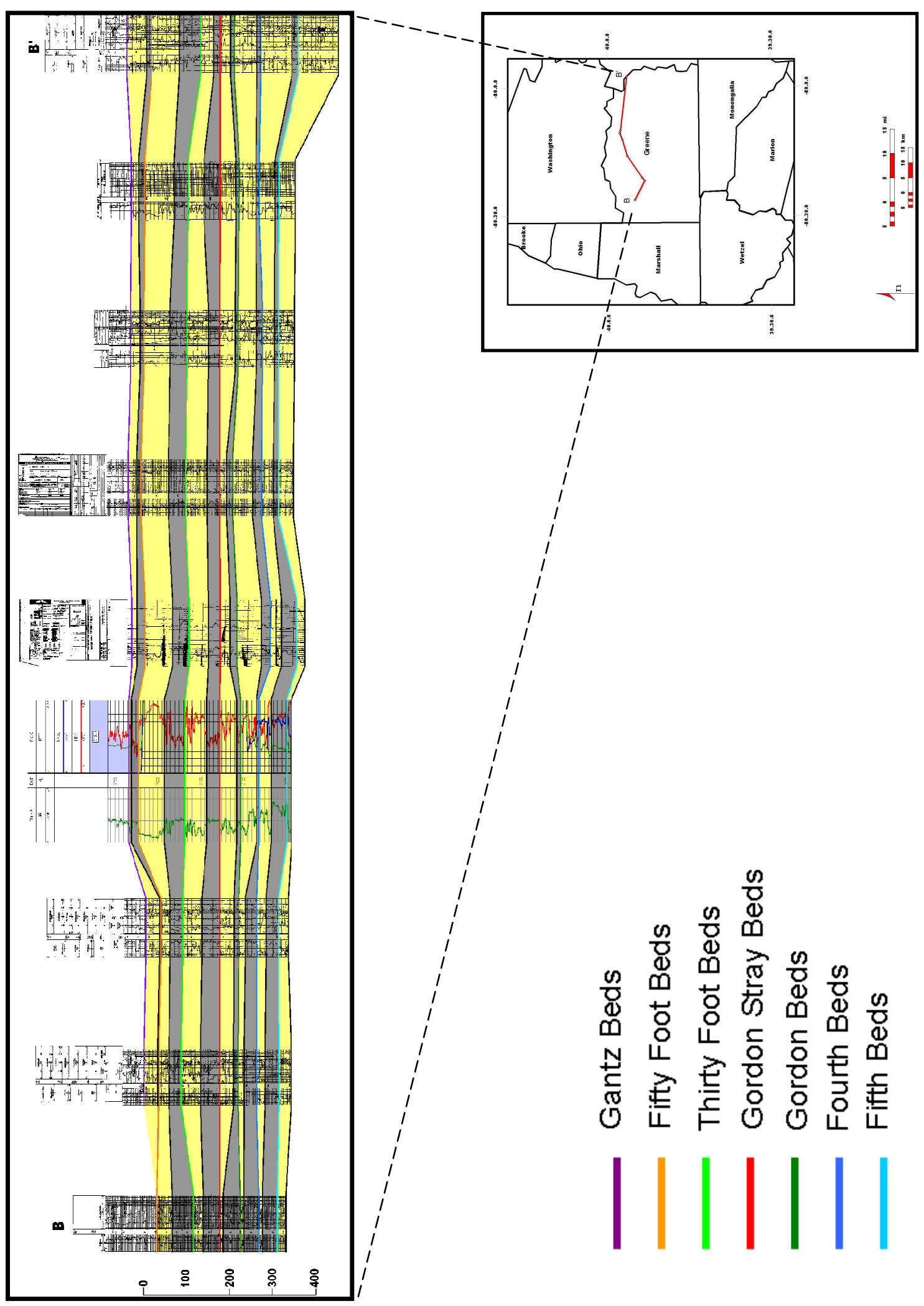

Figure 24. Gross cross-section B-B' showing the distribution of Upper Devonian beds including the Gordon and Gordon Stray across northern Greene County. 


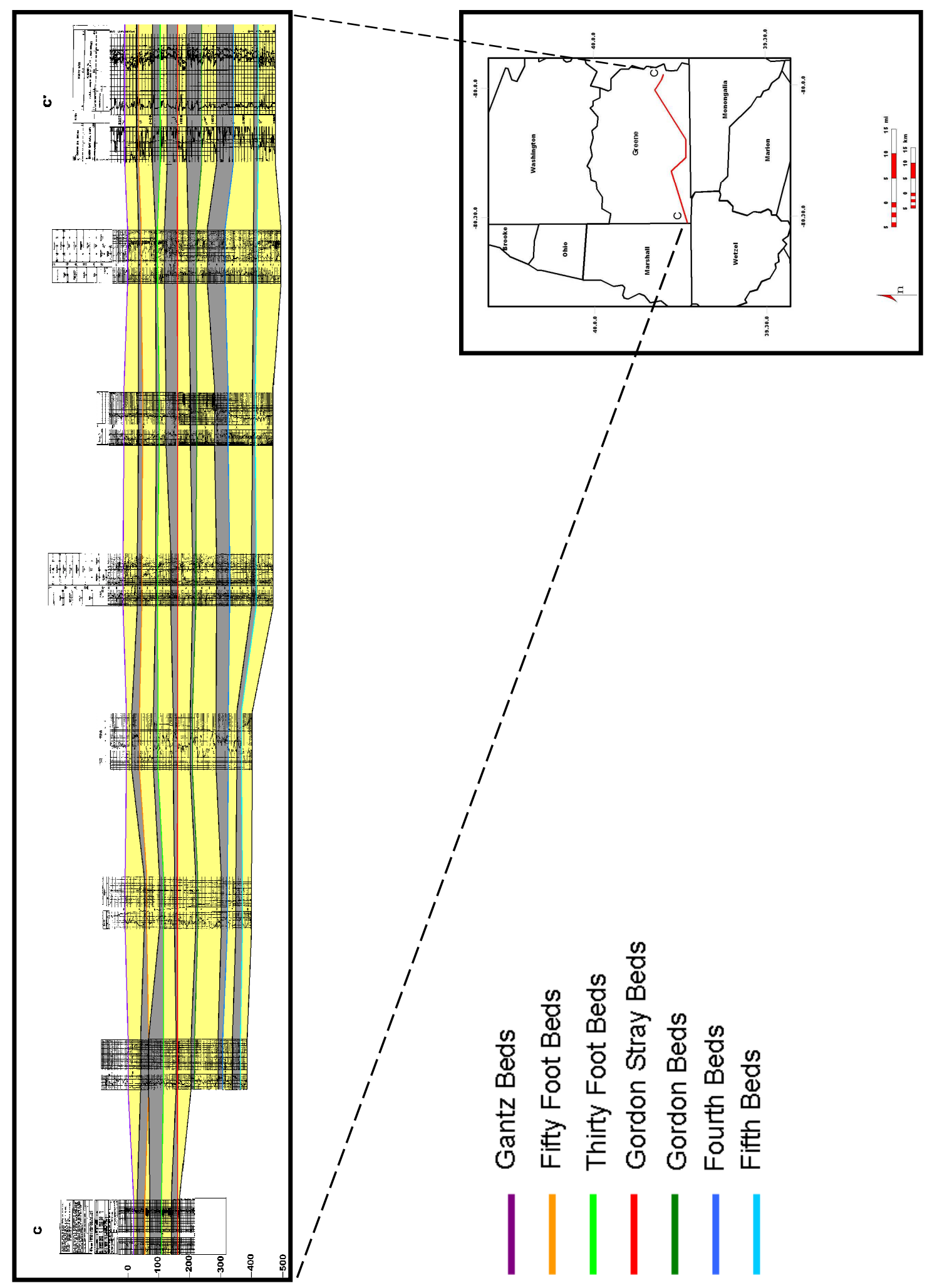

Figure 25. Gross cross-section C-C' showing the distribution of Upper Devonian beds including the Gordon and Gordon Stray across southern Greene County. 

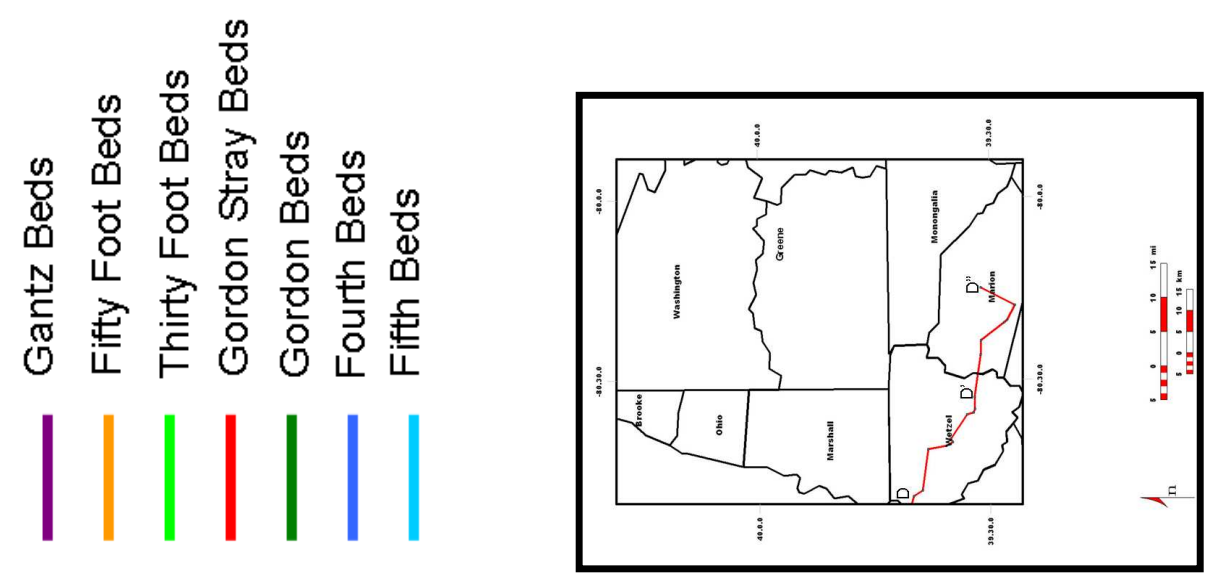

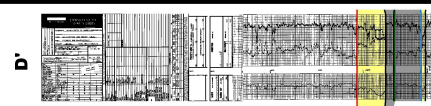

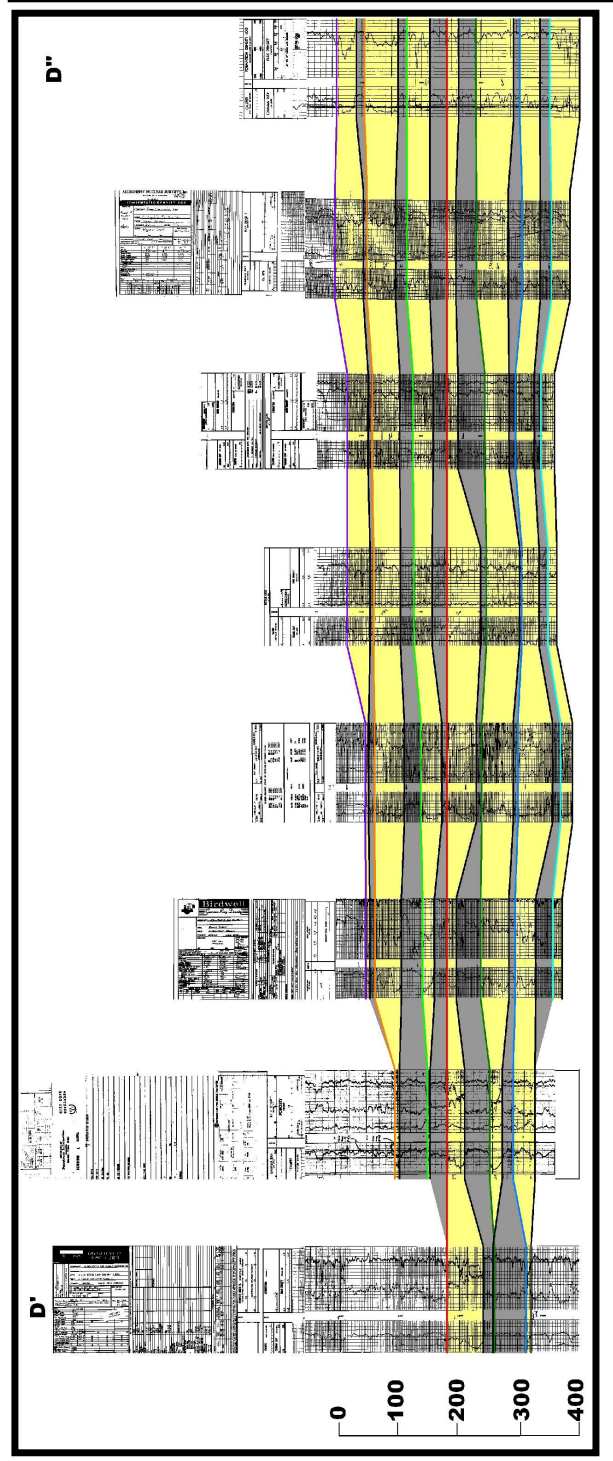

Figure 26. Gross cross-section D-D" showing the distribution of Upper Devonian beds including the Gordon and Gordon Stray across southern Wetzel, and Marion Counties. 


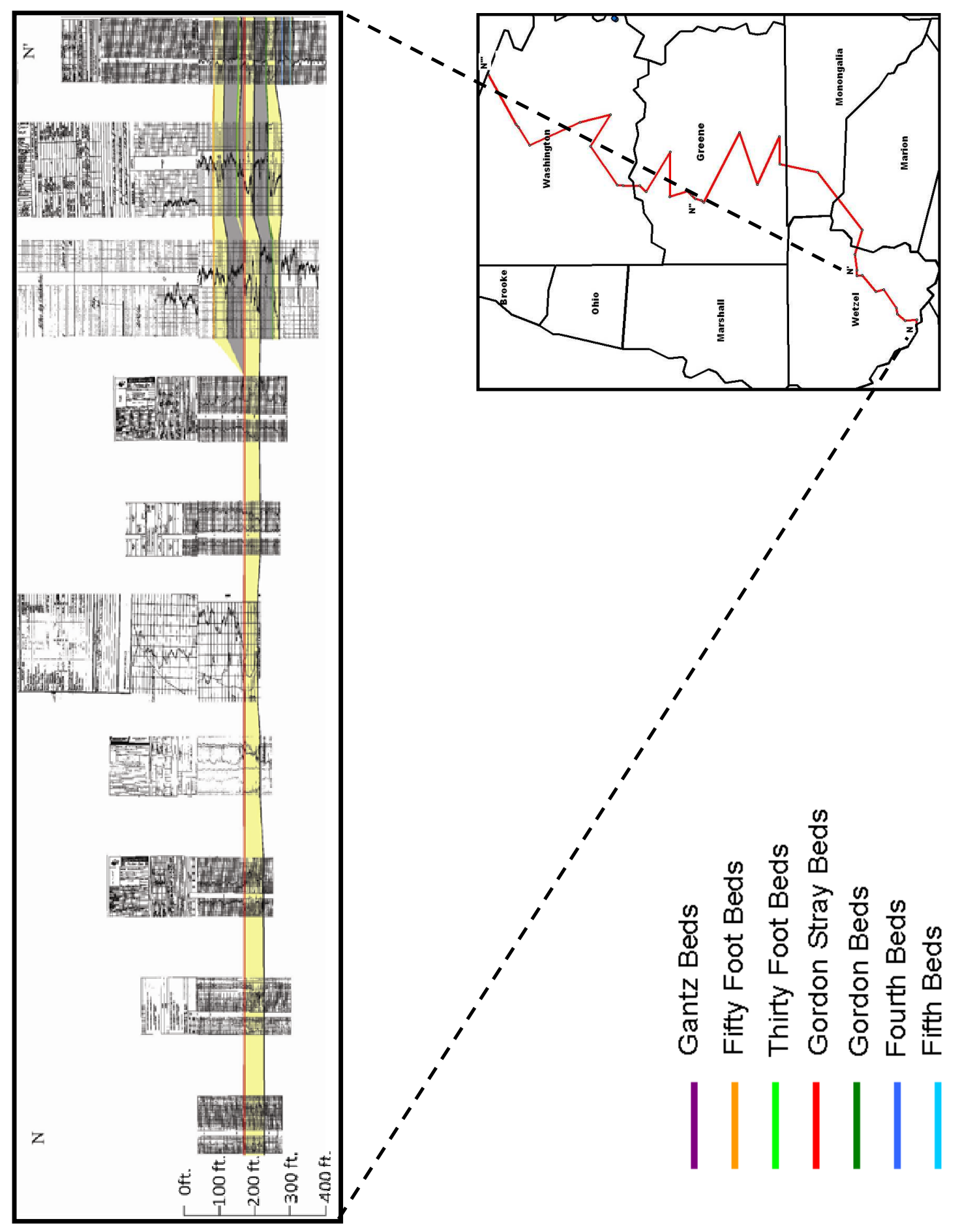

Figure 27. Gross cross-section N-N'" showing the distribution of Upper Devonian beds from north to south including the Gordon and Gordon Stray across the field area. 


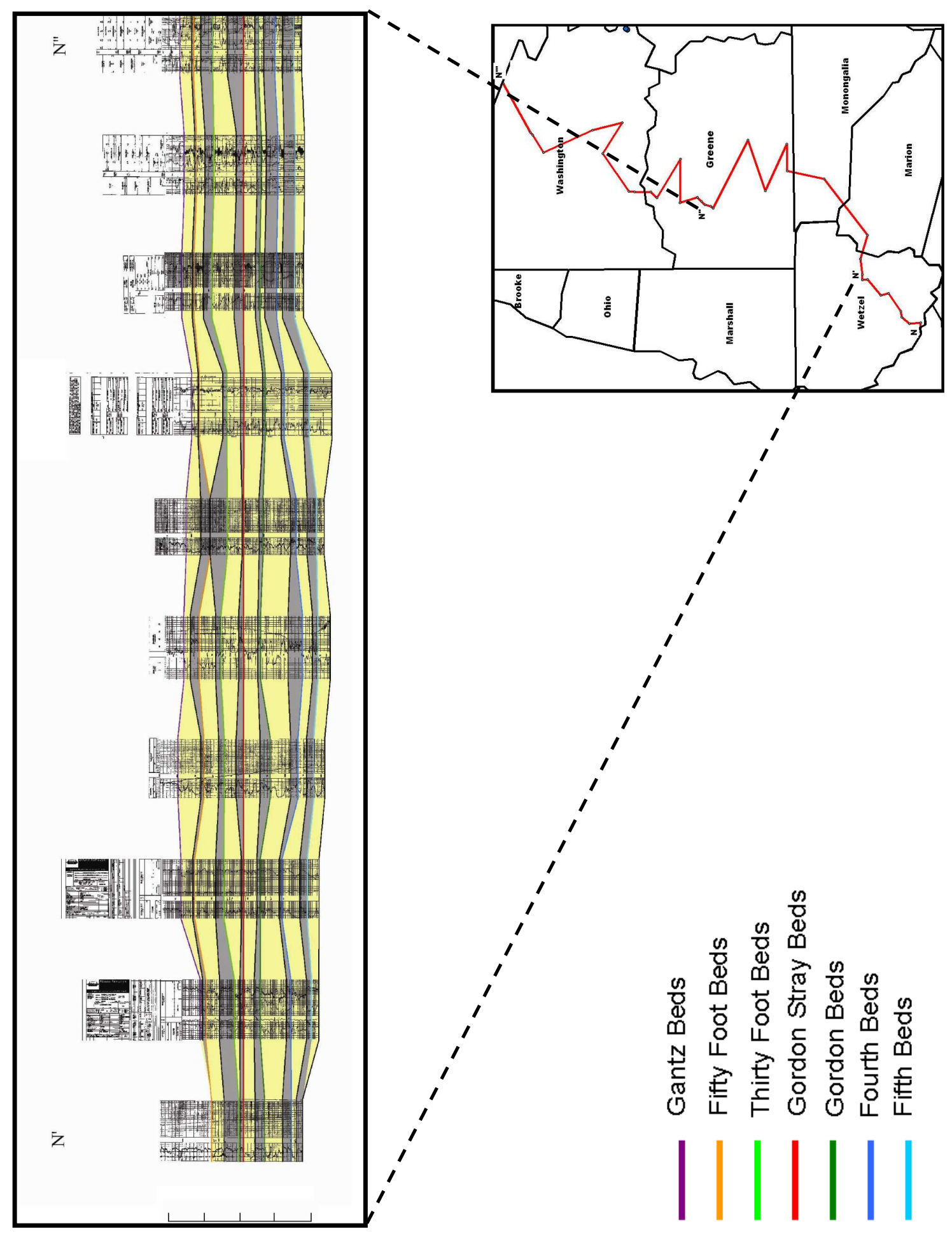

Figure 28. Gross cross-section N-N"" showing the distribution of Upper Devonian beds from north to south including the Gordon and Gordon Stray across the field area. 


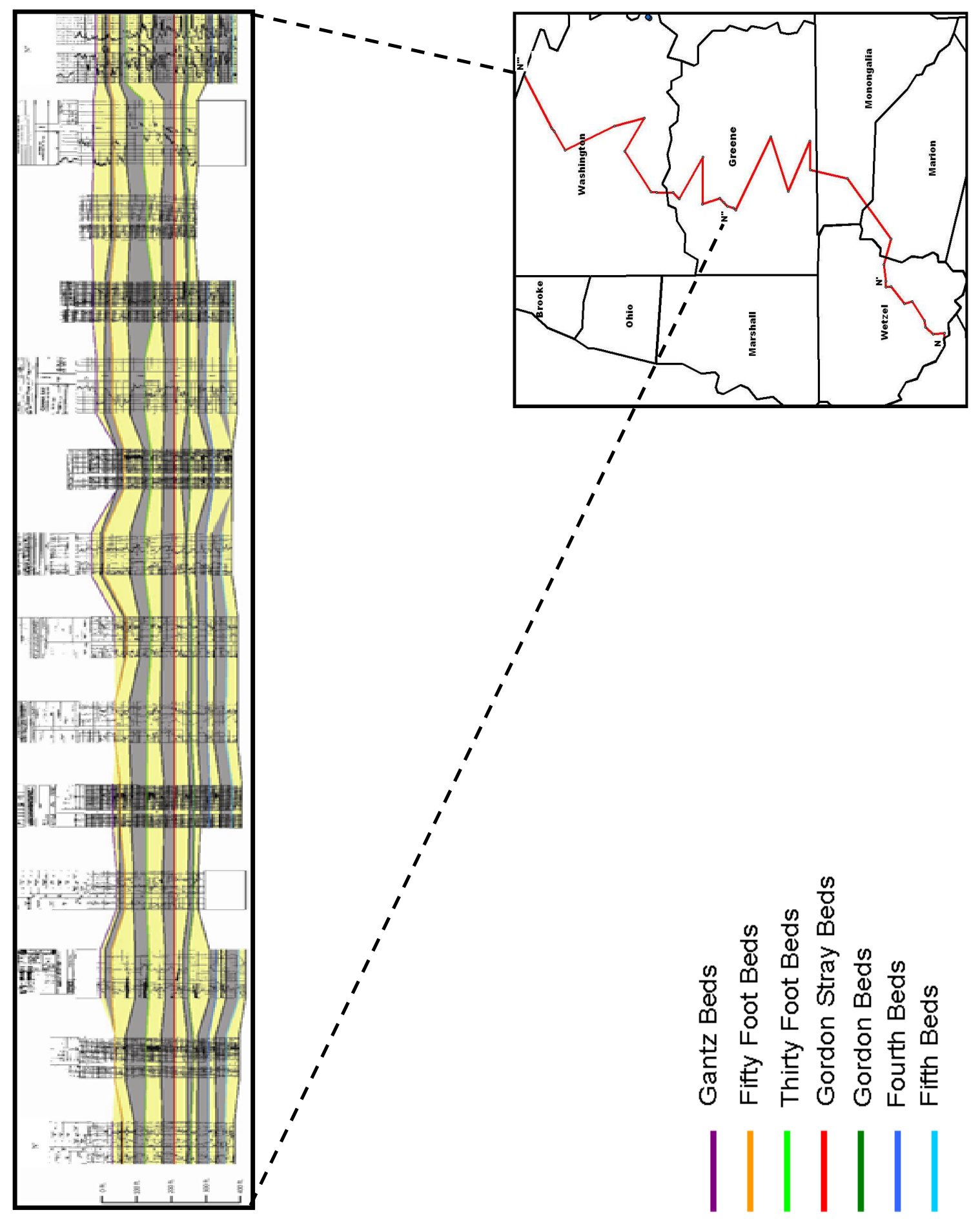

Figure 29. Gross cross-section N-N"' showing the distribution of Upper Devonian beds from north to south including the Gordon and Gordon Stray across the field area. 


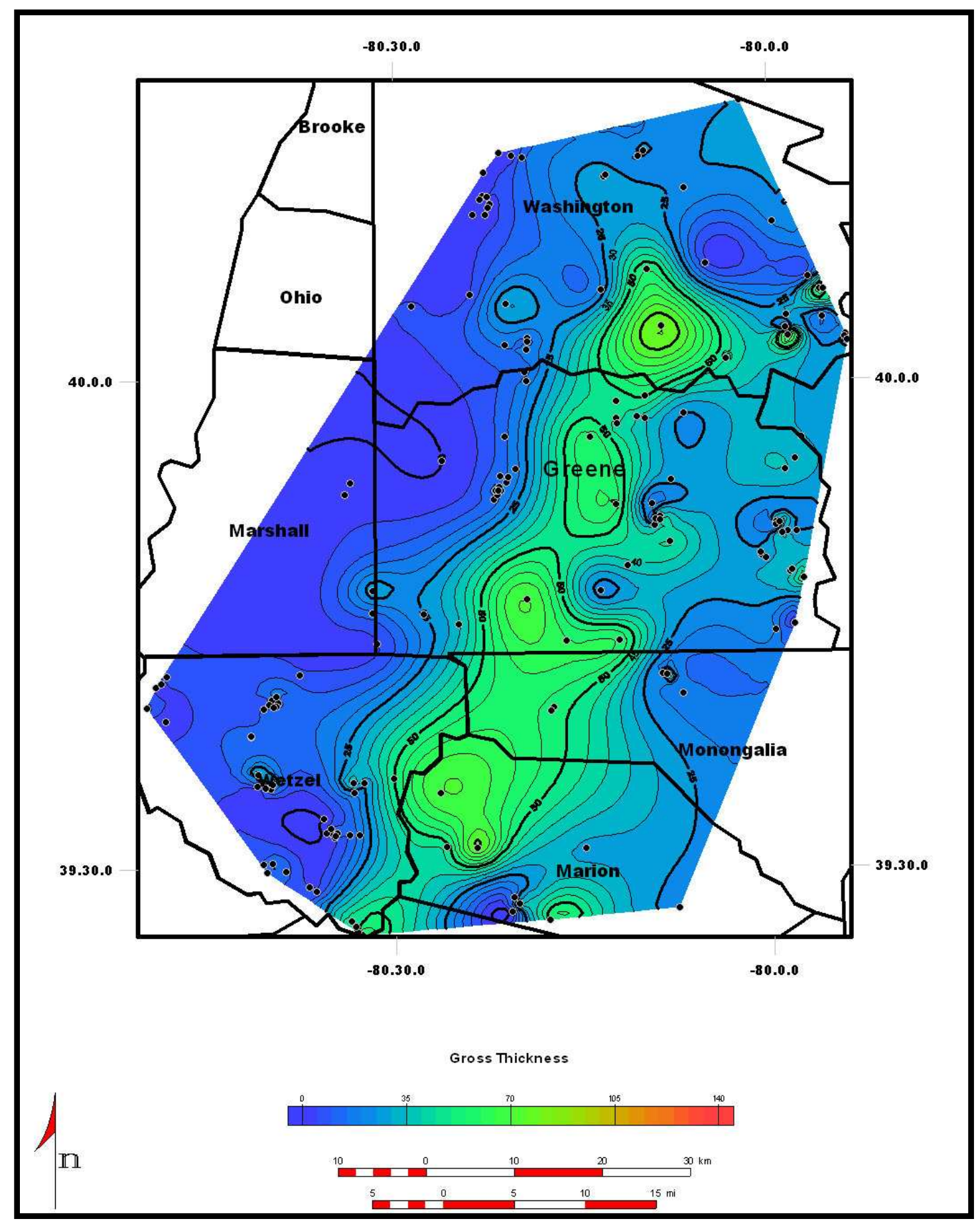

Figure 30. Isopach map of Gordon beds. Dots represent data points. Contour interval is $5 \mathrm{ft}$. 
The thickness of these wedges is as much as $45 \mathrm{ft}$. On the net-sandstone map of the Gordon beds, it is apparent that sandstone comprises only a small percent of the overall Gordon thickness (Fig. 31). This is especially true in central Greene County where total sandstone thickness is $15-30 \mathrm{ft}$. compared to a total interval thickness of $40-70 \mathrm{ft}$. observed on the isopach map (Fig. 30). From the net-sandstone map, Gordon beds are also seen to be more discontinuous and pod-like in central Greene County. To the west, Gordon beds display a tongue-like gamma-ray response. Similar distribution can be seen in the center of the study area where the thickness of the Gordon beds change dramatically, from 1-2 ft. sandstone tongues to 26-30 ft of clean sandstone. Gamma-ray response is also variable in the center of the study area. Responses range from blocky to concave to fining upwards. Thickness of Gordon beds gradually thin in the east. In the easternmost section of the study area, beds display a spiky pattern on the gamma-ray log, reflecting an alternation of sandstone and shale.

Net cross-sections A-A', B-B', C-C', and D-D' of the Gordon beds were constructed to further demonstrate sandstone distribution. In southern Greene County, cross-section $\mathrm{C}-\mathrm{C}^{\prime}$ show a stacking of thin sandstones to the west (Fig. 32). Beds thicken in the central area, whereas to the east the Gordon interval becomes shale rich. Gammaray response show beds are fork-like to the west, but become blocky to concave in the central study area. To the east, well logs show beds become seriated or spiky, reflecting alternating sandstone and shale. In northern Greene County, cross-section B-B' show Gordon beds are consisted of one single sandstone body to the west, and alternating clean sandstone and shale in the central part of the county (Fig. 33). Well logs show beds have a clean blocky gamma-ray response to the west, and to the east beds consist of 


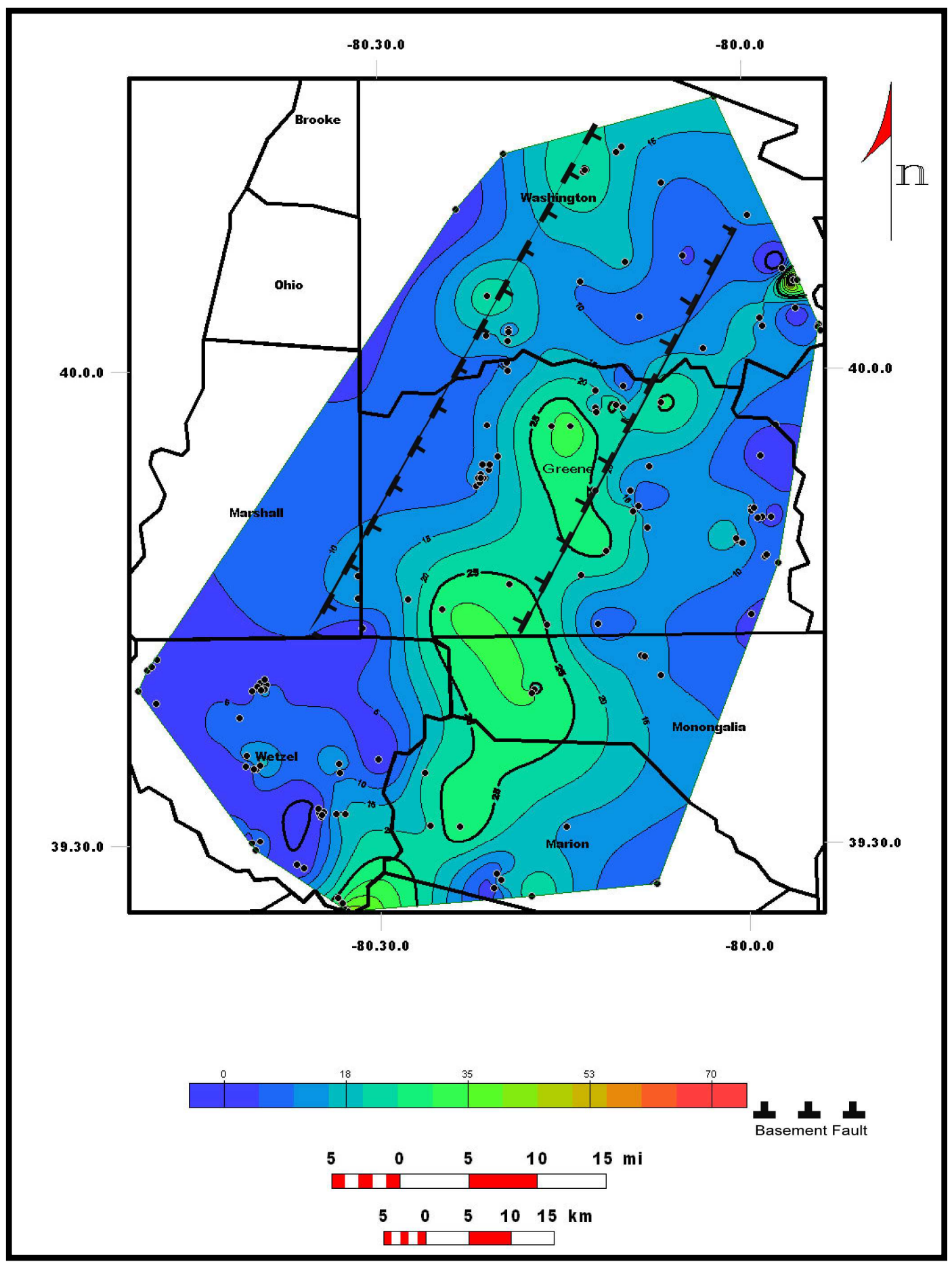

Figure 31. Gordon net-sandstone map. Dots represent data points. Contour interval is $2 \mathrm{ft}$. Basement faults from Wagner (1977). 


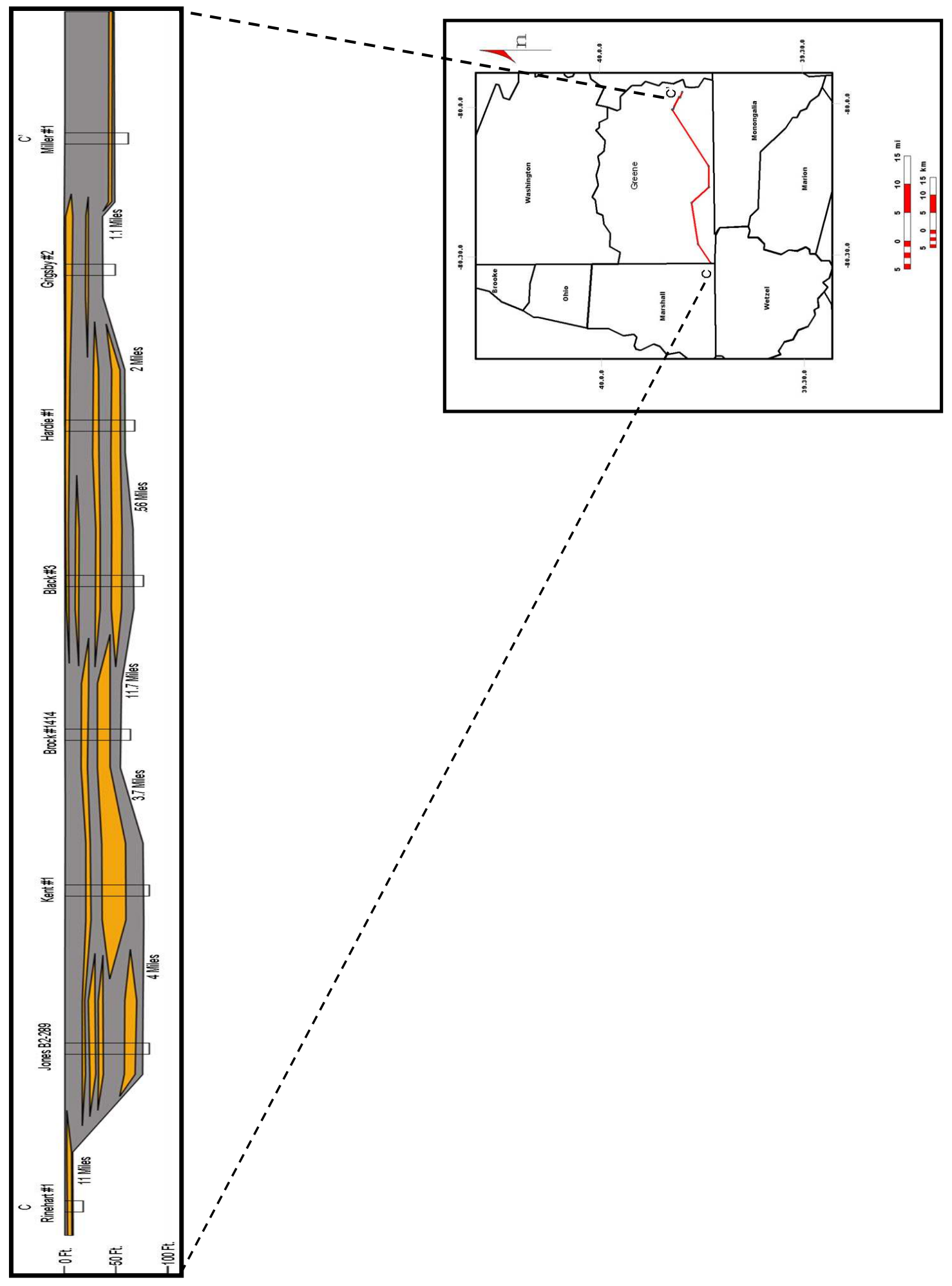

Figure 32. West to east cross section C-C' showing the distribution of Gordon beds across southern Greene County. Yellow areas indicate sandstone with API values 80 API or less, and grey areas indicate shale with API values above 80. 


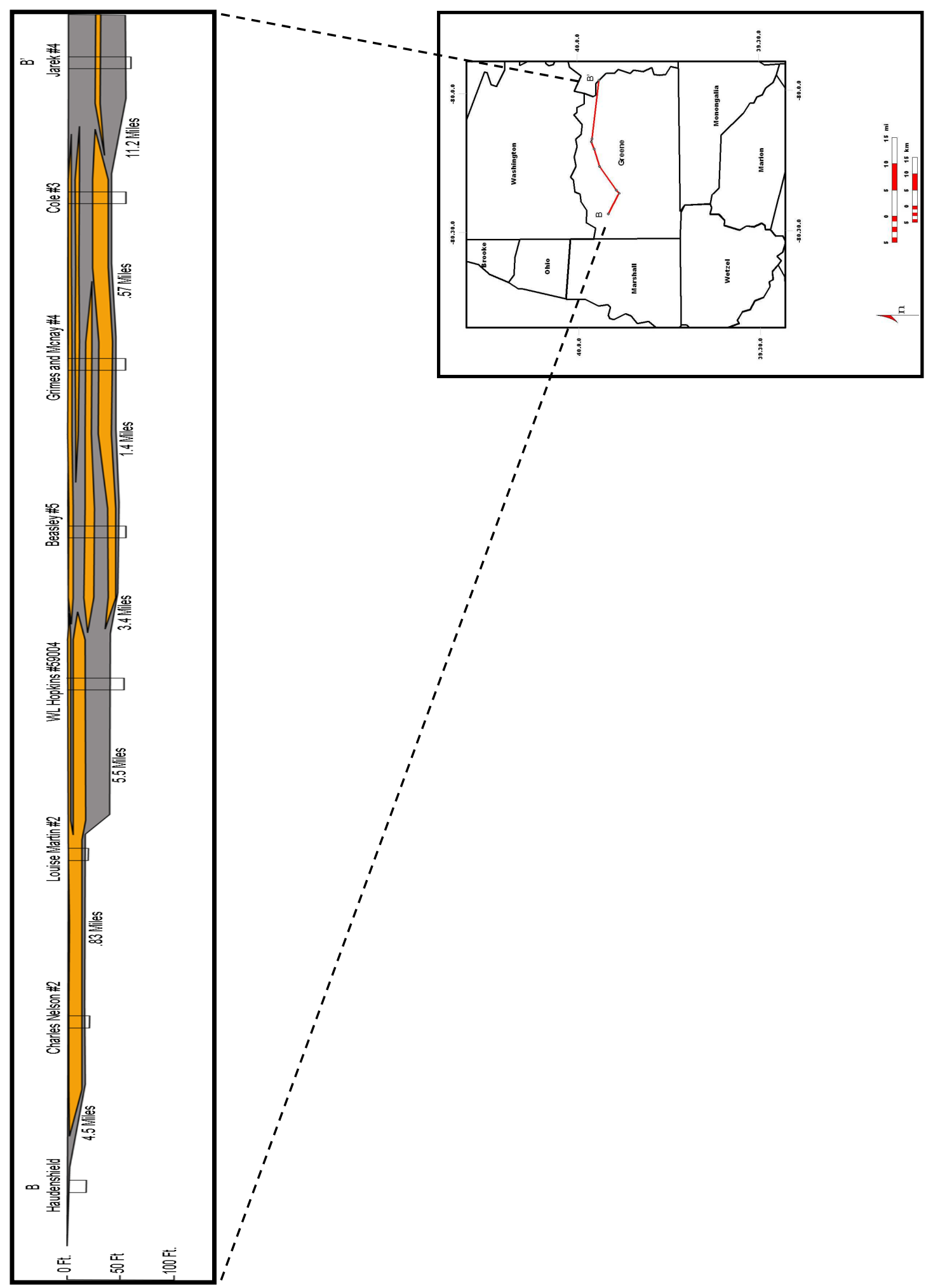

Figure 33. Cross-section B-B' showing the distribution of the Gordon beds across northern Greene County. Orange areas represent sandstone with API values 80 API or less. Grey areas indicate shale with values greater than 80 API. 
alternating sandstone and shale similar to what is observed in cross-section C-C'. East of the main isopach thick in Marion County, cross-section D-D" shows that the Gordon beds consist of one clean blocky sandstone thick to the west. However, beds become increasingly characterized by interbedded sandstone and shale to the east. In fact, the Gordon beds become increasingly difficult to differentiate on well logs downsection from the Fourth beds to the east (Fig. 34). Both units here consist of alternating shale and sandstone. Similar trends can be seen in northern Washington County across crosssection $\mathrm{A}-\mathrm{A}^{\prime}$ to the east and west. In contrast, Gordon beds consist of a single blocky sandstone in this part of the study area. 

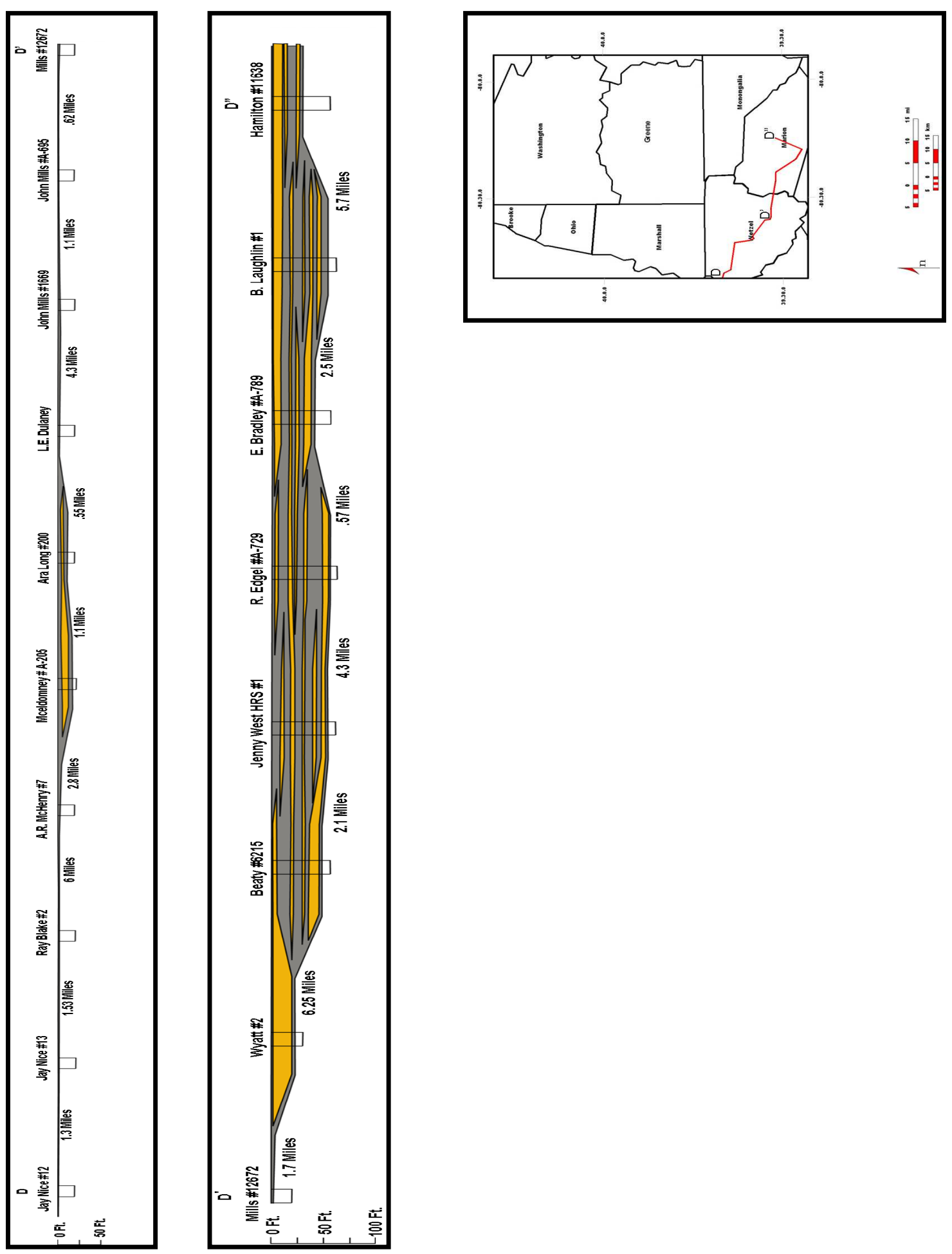

Figure 34. Cross-section D-D" showing the distribution of Gordon beds across Wetzel and Marion Counties West Virginia. Orange areas represent sandstone with API values 80 API or less. Grey areas indicate shale with values greater than 80 API. 


\section{Gordon Stray Beds}

The isopach map generated for the Gordon Stray beds reveals several interesting trends (Fig 35). The central sandstone comprises a linear thick extending due north for 42 miles from Monongalia County to Washington County. Thickness is generally $40 \mathrm{ft}$. or less although at the southern end of the main body it obtains a thickness of $55 \mathrm{ft}$. Average width is 8 miles. A southern thick runs from northeastern to southwestern Wetzel County and strikes approximately N42E. The length of the southern sandstone body is 18 miles, and its width averages 7 miles. To the west of the main sandstone trend, thickness rapidly decreases and the Gordon Stray beds become increasingly shaly. To the east of the main sandstone trend, several isolated pod-like bodies are recognized in Marion and Greene counties. In Marion County, one pod-like sandstone body has a maximum thickness of 30 ft. The pod-like feature in Greene County reaches a thickness of $45 \mathrm{ft}$. To the east, sandstone thickness decreases gradually and becomes irregular, a pattern that is better characterized on the net-sandstone map (Fig. 36).

Comparing the isopach map (Fig. 35) to the net-sandstone map (Fig. 36) reveals both similarities and differences. The two differ in thickness, of course, but the trend is basically the same. The Gordon Stray beds consist of an elongate shoreline-parallel sandstone body trending roughly due north with a length of approximately 42 miles and a width of roughly 7 miles. Thickness of this feature varies but generally it is greater than $15 \mathrm{ft}$. 


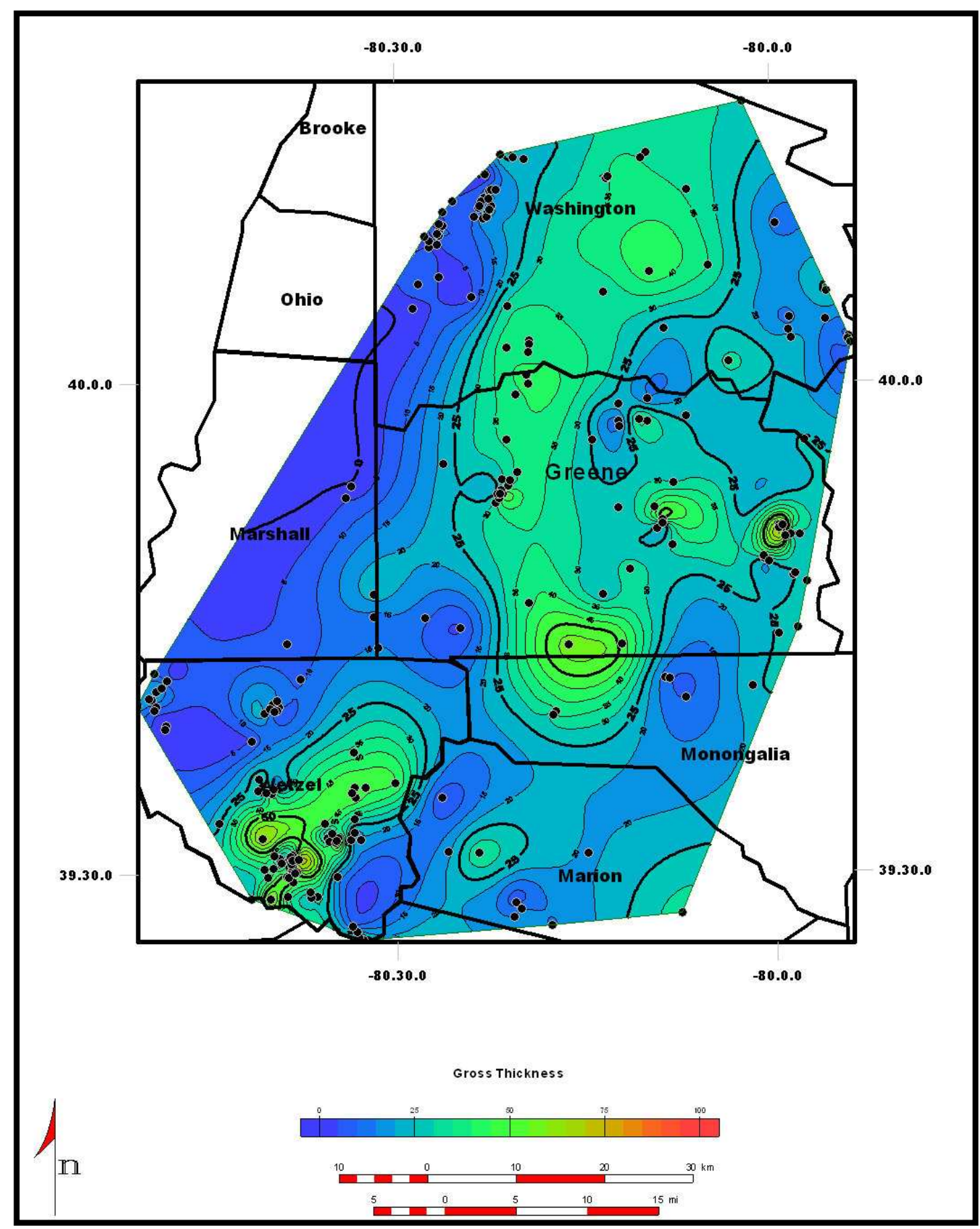

Figure 35. Isopach map of Gordon Stray beds. Dots represent data points. Contour interval is $5 \mathrm{ft}$. 


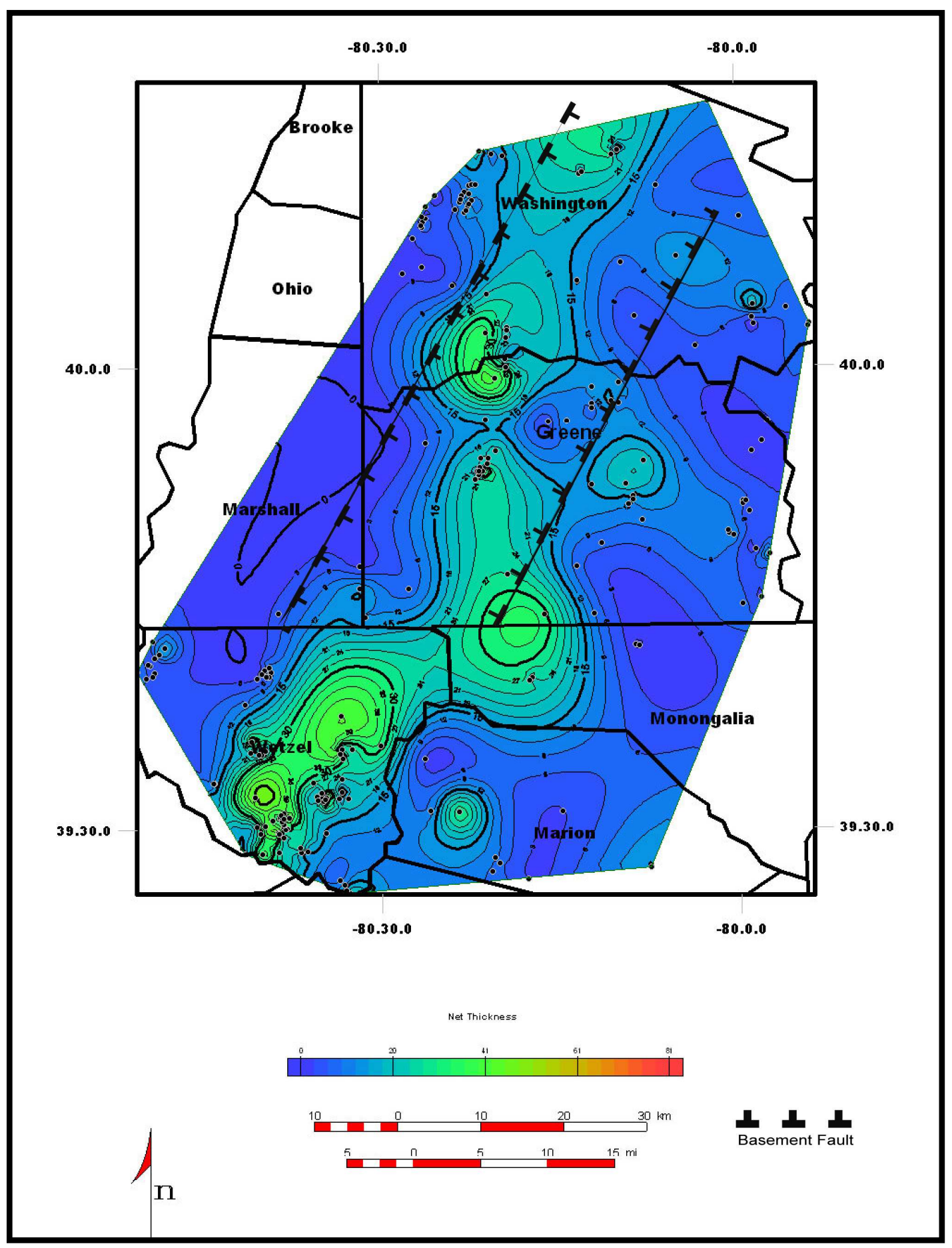

Figure 36. Gordon Stray net-sandstone map. Dots represent data points. Contour interval is $2 \mathrm{ft}$. Basement faults from Wagner (1977). 
A second elongate thick is observed in Wetzel County. In the eastern part of the study area lie pod-like sandstone thicks of various sizes. To the west, well-logs show that the Gordon Stray beds are thin and display a tongue-like gamma-ray response. In the central area, Gordon Stray beds consist of clean sandstone at the base, fining upwards to shale at the top. The sandstone comprises one or two blocky, clean, amalgamated bodies. Where there are multiple beds, sandstone is separated by minor shale breaks, and they are vertically stacked. In the easternmost part of the area, the beds thin and become more interbedded with shale. The cross section C-C' was generated to demonstrate this sandstone distribution of the Gordon Stray beds across southern Greene County (Fig. 37). From this cross-section it is evident that Gordon Stray beds rapidly thicken in the central study area consisting of multiple stacked sandstone bodies. The sandstone bodies thin and become shale rich to the east. Although thinner in northern Washington County and northern Greene County, similar distribution of sandstone is evident in cross section BB', and A-A' (Fig 38 and 39). Cross-Section D-D'" shows the distribution of Gordon Stray beds across Wetzel and Marion Counties (Fig. 40). Gordon Stray beds are thin and discontinuous in the western portion of Wetzel County. The beds rapidly thicken across the central and eastern portions of the county, however. Gordon Stray beds become increasingly shale rich to the east in Marion County.

Cross-sections displaying sandstone distribution of both the Gordon and the Gordon Stray beds were constructed to compare the two stratigraphically. To the north in Washington County, cross-section A-A' shows the Gordon beds consist of one main sandstone bed whereas the Gordon Stray beds consist of multiple stacked sandstone bodies (Fig. 41) To the south in Greene County, the Gordon beds have a somewhat 


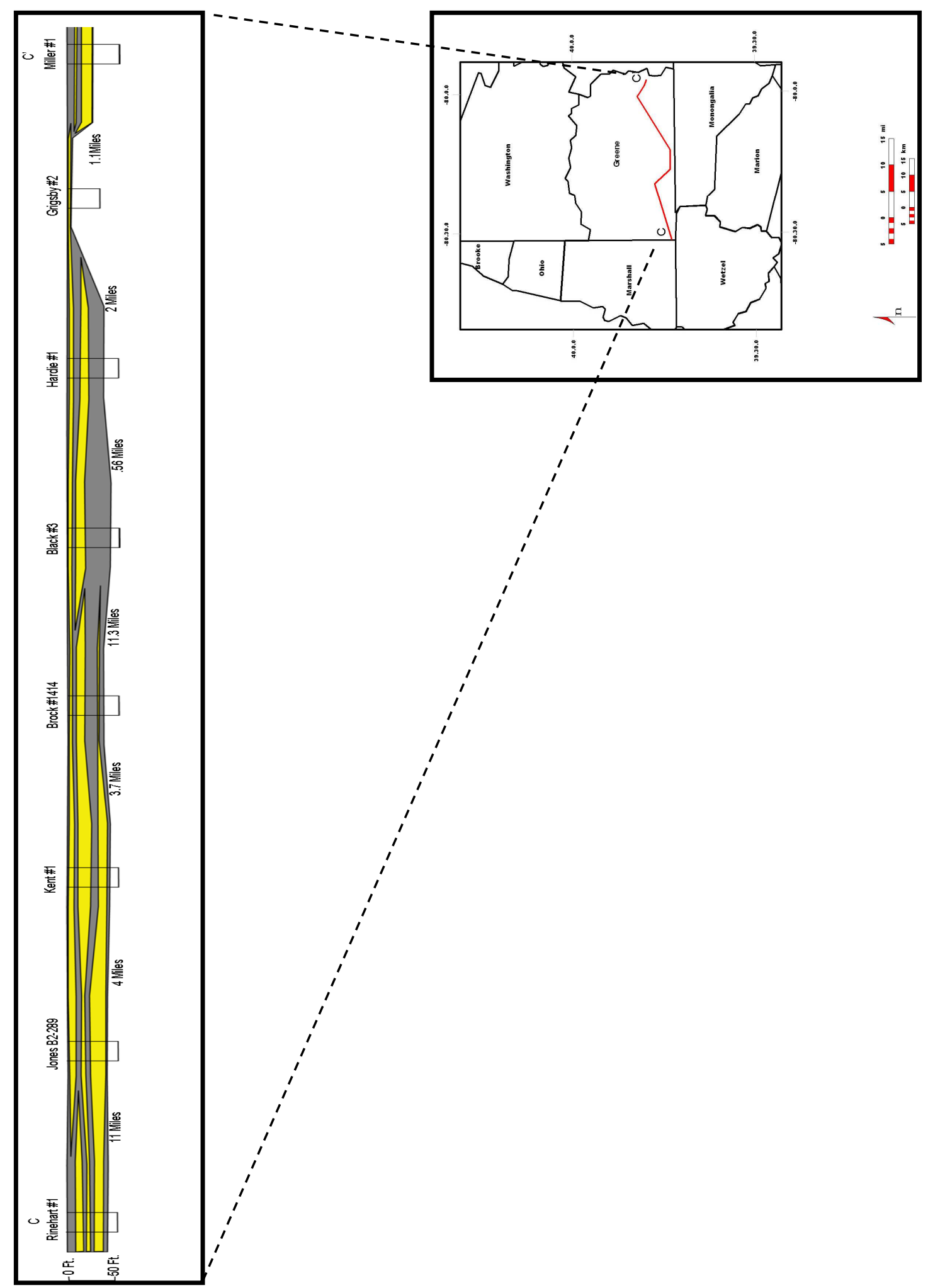

Figure 37. East to west cross-section C-C' showing the distribution of Gordon Stray beds across southern Greene County. Yellow areas indicate sandstone of 80 API or less. Grey areas represent shale with values higher than 80 


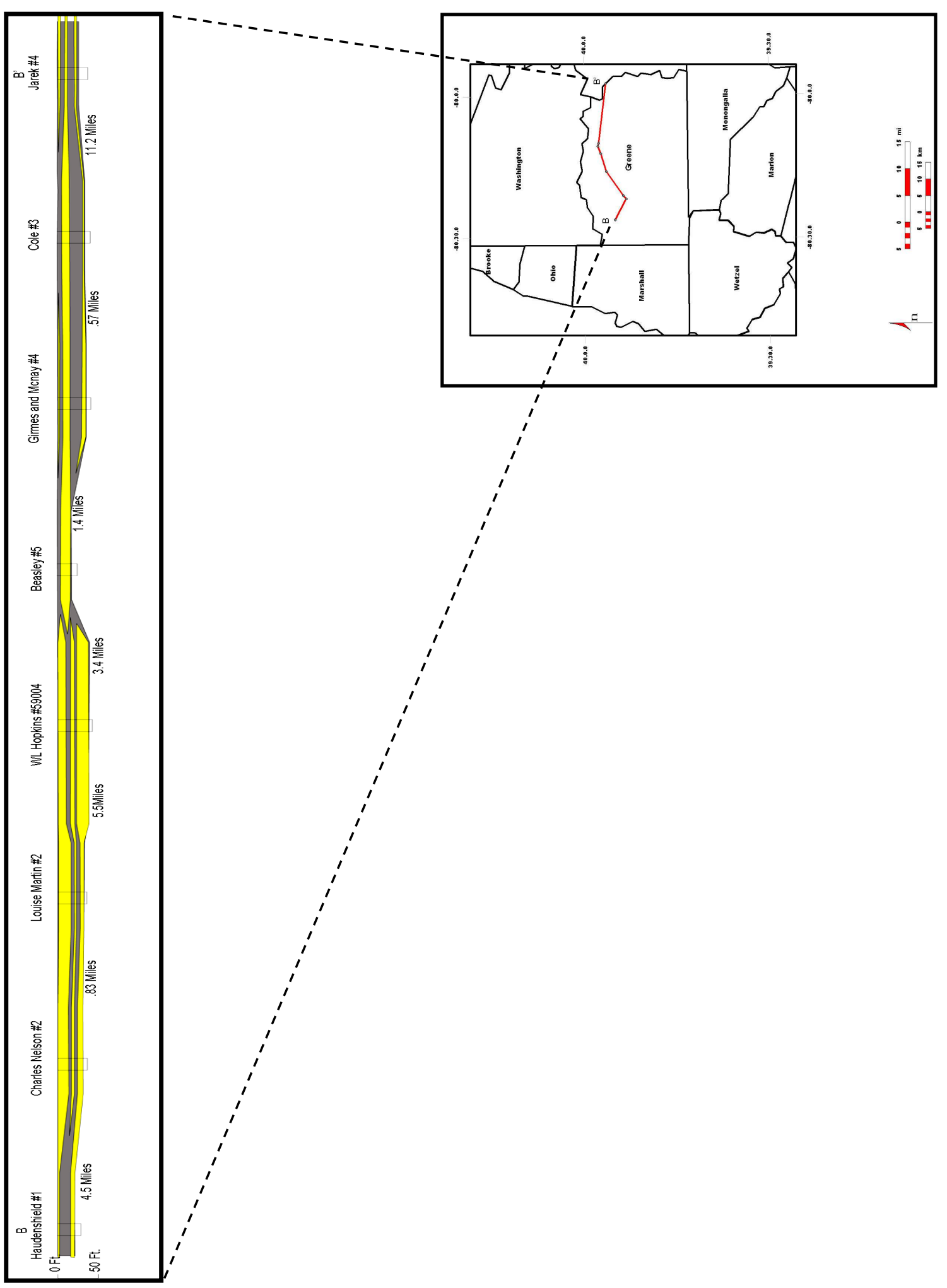

Figure 38. Cross-section B-B' showing the distribution of Gordon Stray beds across northern Greene County. Yellow indicates sandstone with API values 80 API or less. Grey areas represent shale with values greater than 80 API. 


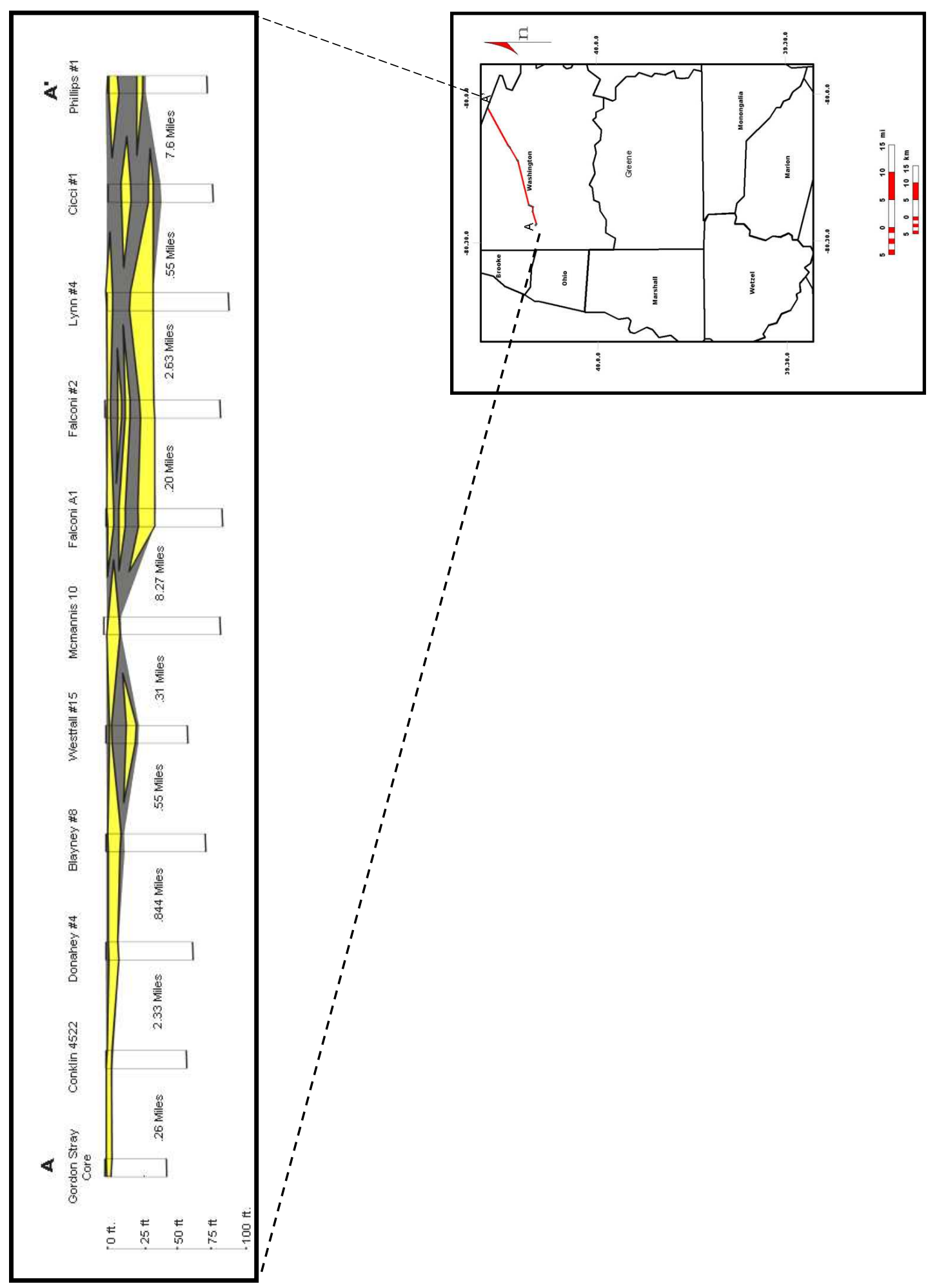

Figure 39. East to west cross-section A-A' showing the distribution of the Gordon Stray beds across northern Washington County Pennsylvania. Yellow areas indicate sandstone of 80 API or less. Grey areas represent shale with values higher than 80 API. 

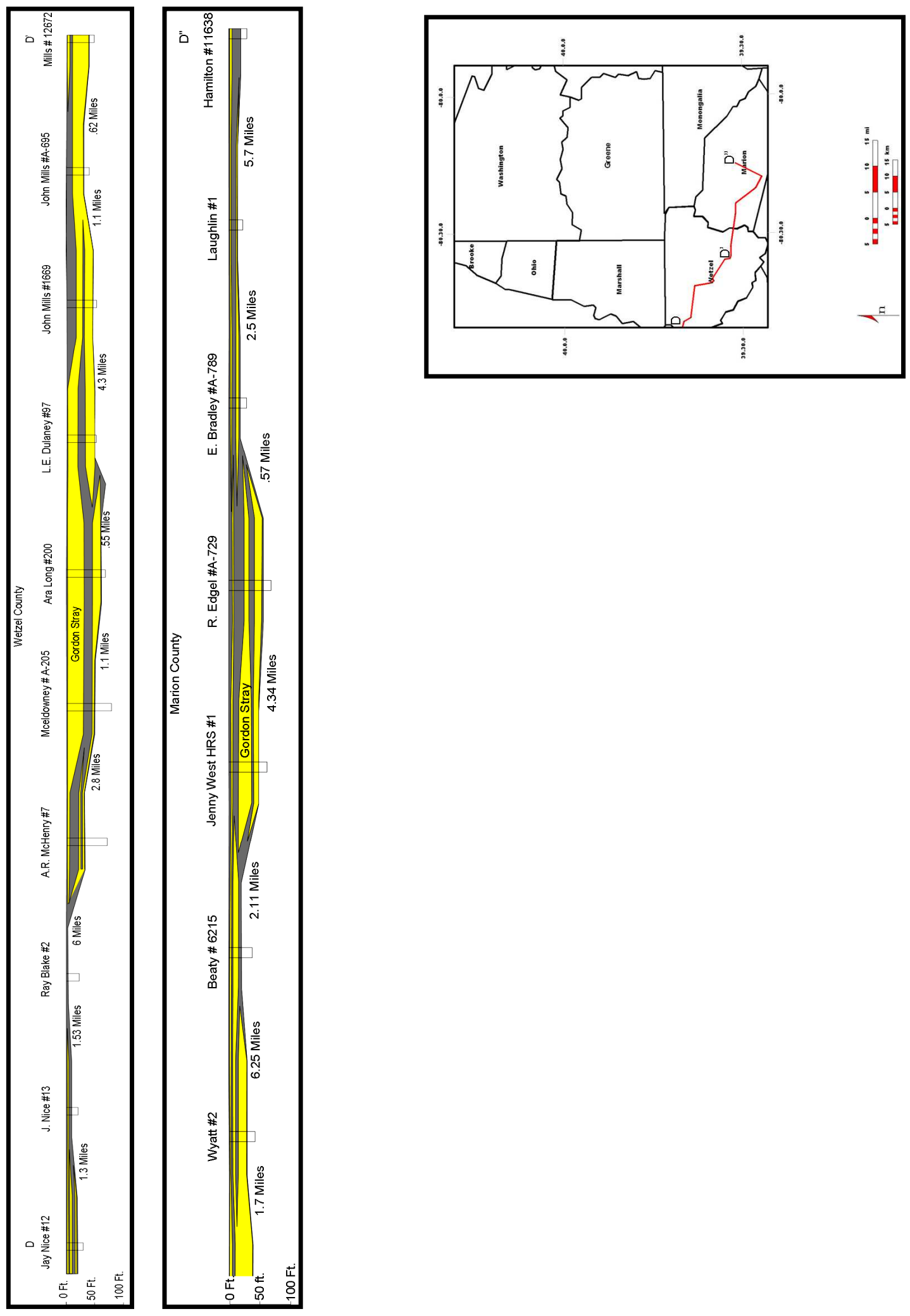

Figure 40. Cross-section D-D', showing the distribution of the Gordon Stray beds across Wetzel and Marion Counties West Virginia. 


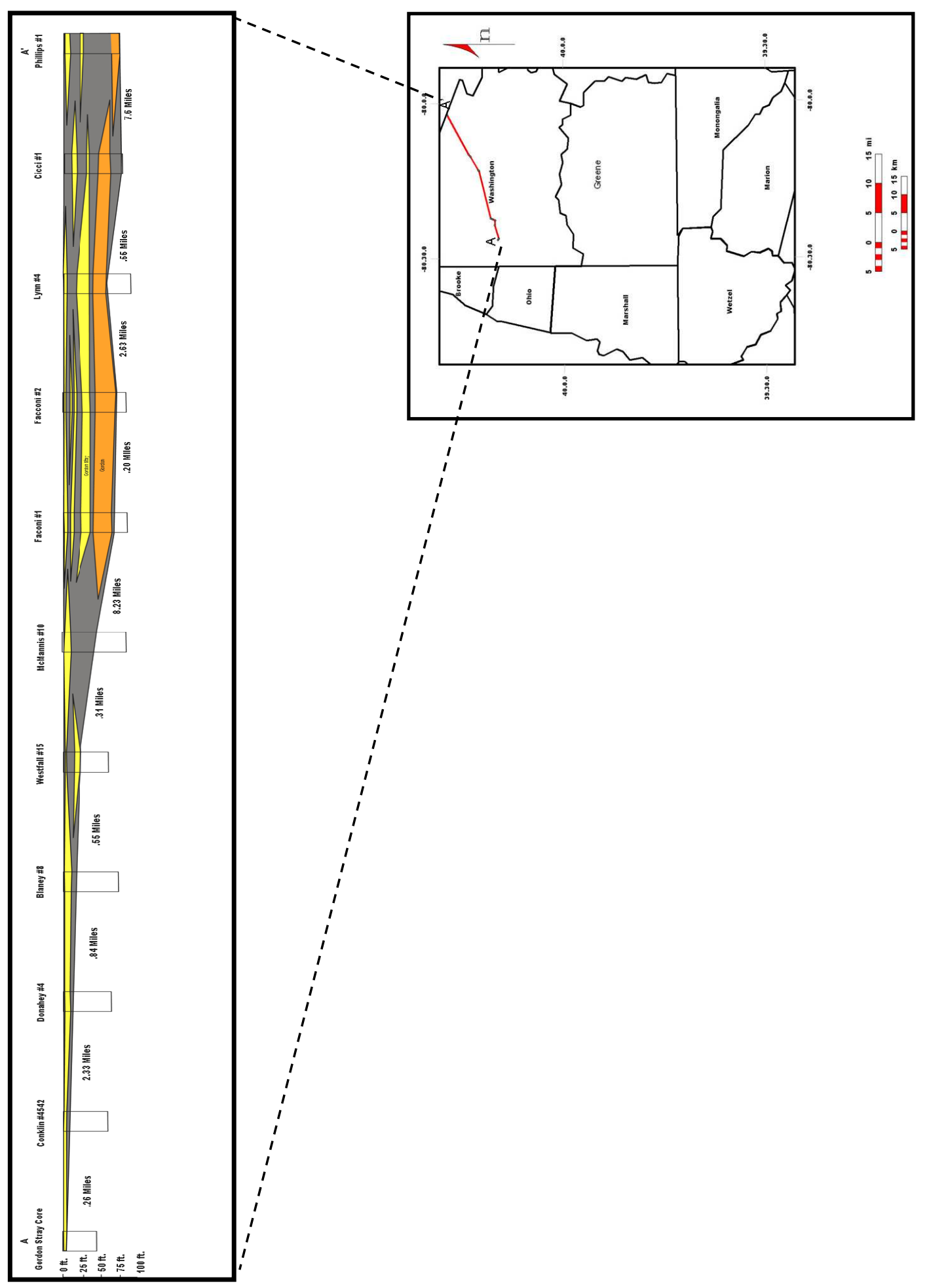

Figure 41. Cross-section A-A' showing the Gordon interval in the subsurface of northern Washington County Pennsylvania. Yellow colors indicate Gordon Stray beds. Orange colors indicate Gordon beds. 
different stacking pattern than in the north as is seen in cross-sections B-B', and C-C' (Figs. 42 and 43) The Gordon interval is much thicker than in Washington County, and displays a higher percentage of shale in the interval. Gordon Stray beds have a similar distribution to the beds in Washington County across Greene County displaying multiplestacked sandstone. To the south in Wetzel and Marion counties, cross-section D-D', shows that the Gordon beds are thin and consist of one sandstone body in eastern Wetzel County (Fig. 44). The Gordon beds become increasingly thicker in Marion County but the interval is consisted of highly interbedded sandstone and shale. The Gordon Stray beds are thicker and laterally more persistent than the Gordon beds across Wetzel County extending further to the west. 


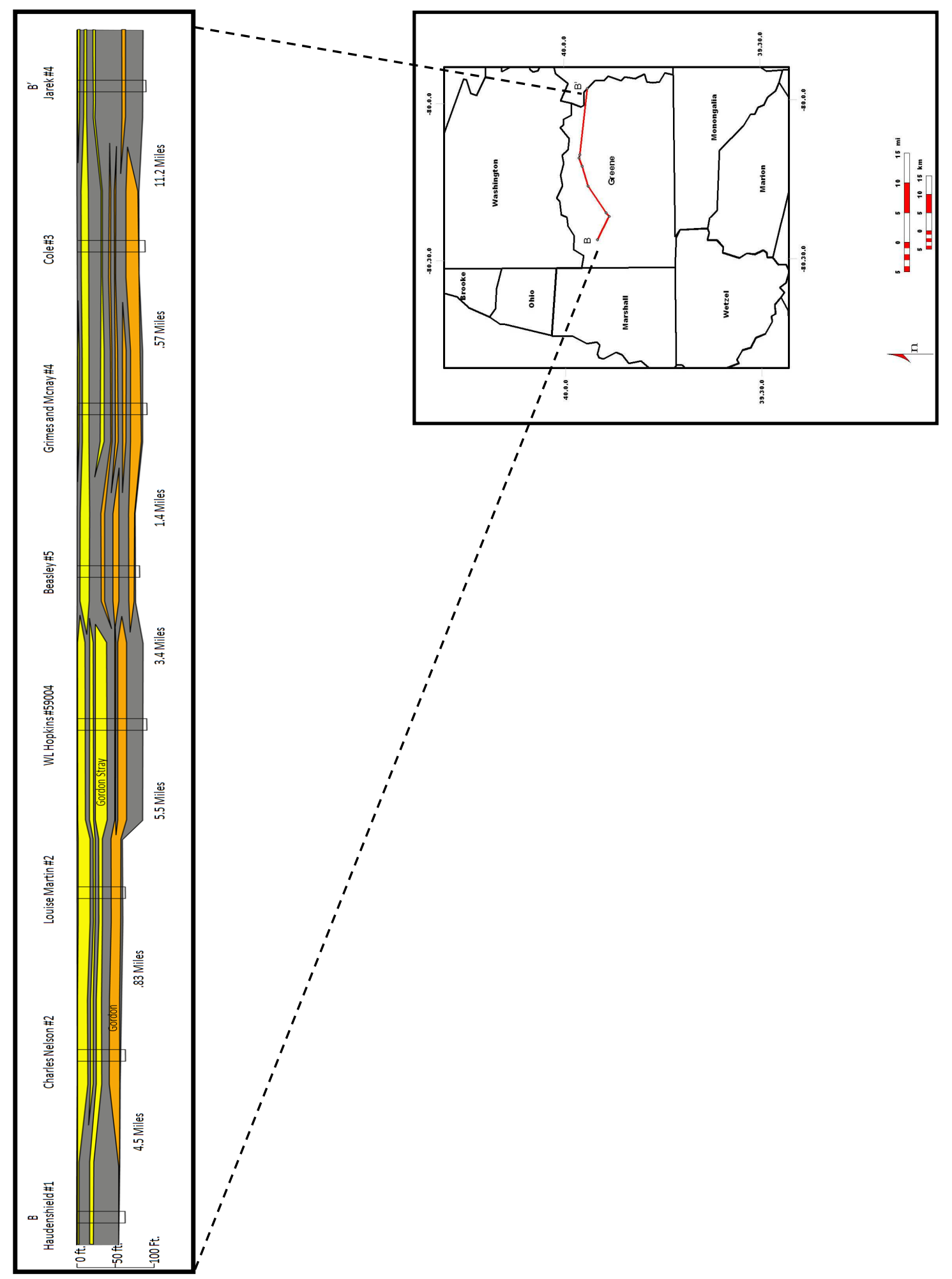

Figure 42. Cross-section B-B' showing the Gordon interval across northern Greene County, Pennsylvania. Yellow colors indicate Gordon Stray beds. Orange colors indicate Gordon beds. Grey area represents shale with gamma ray API values greater than 80 API. 


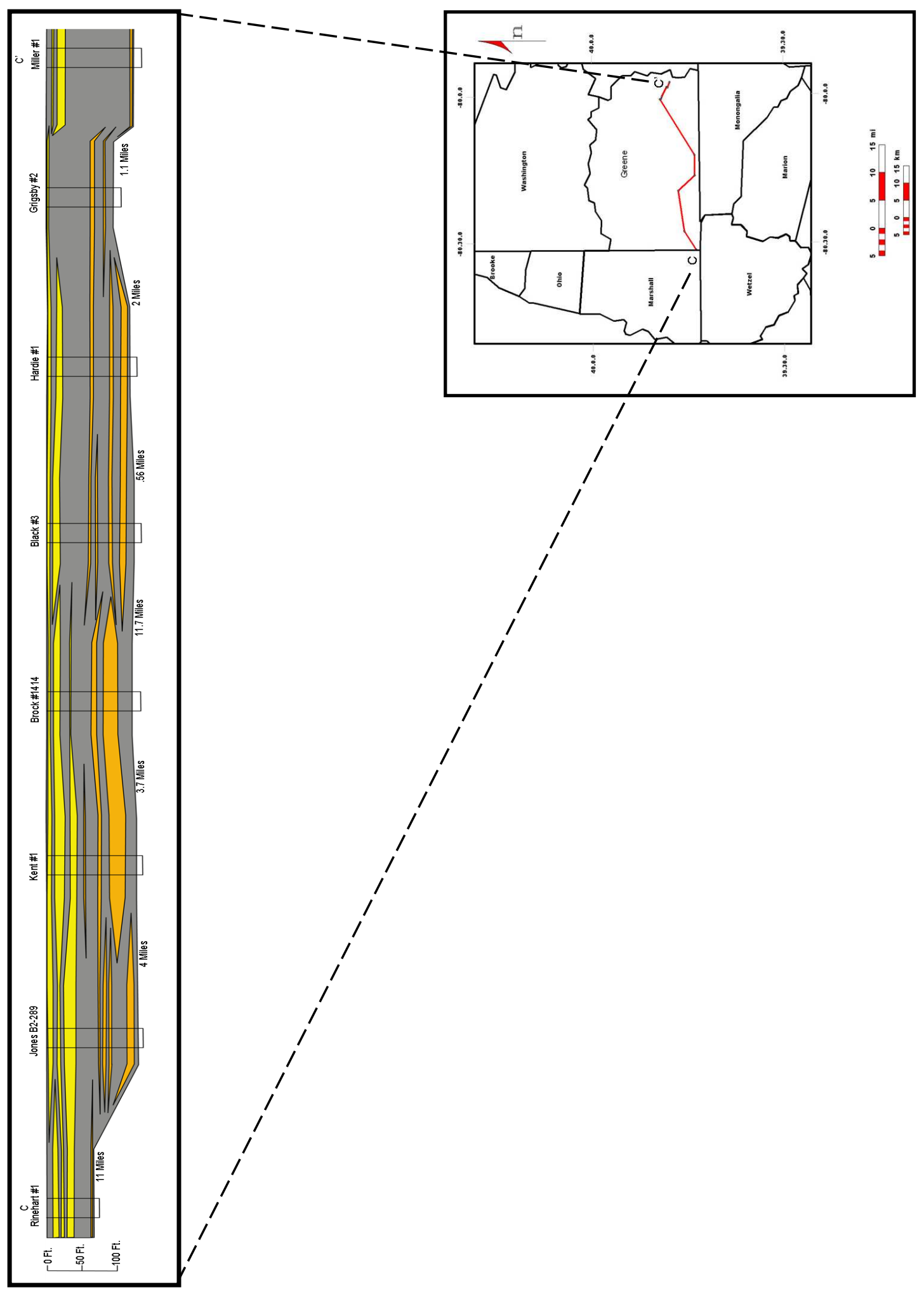

Figure 43. Cross-Section C-C' showing the Gordon interval in the subsurface of southern Greene County, Pennsylvania. Yellow colors indicate Gordon Stray beds. Orange colors indicate Gordon beds. 

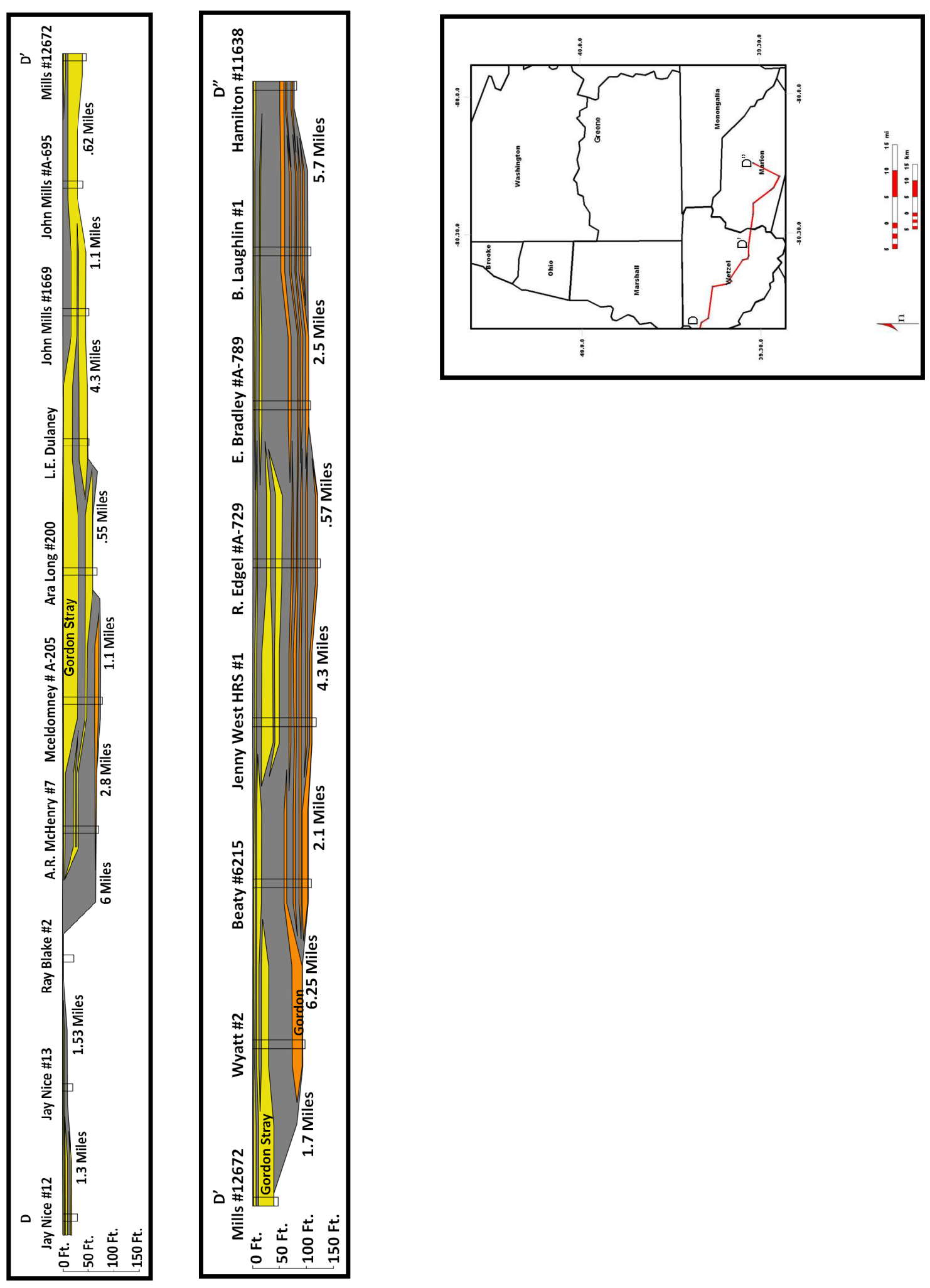

Figure 44. Cross section D-D",' showing Gordon interval across Wetzel and Marion Counties, West Virginia. Yellow colors indicate Gordon Stray beds. Orange colors indicate Gordon beds. Grey areas indicate shale with values greater than 80 API. 


\section{Gordon Stray Core}

A full-bore core of the Gordon Stray beds from Washington County, Pennsylvania, was described, studied, and compared to both well logs and a formation micro-imager log (FMI) (Figs. 45 and 46). In the core, the Gordon Stray beds were divided into 5 units (Units 5-9a, see Appendix) having a total thickness of $3.3 \mathrm{ft}$. The Gordon Stray beds consist of conglomerate and sandstone with some siltstone. The base of the Gordon Stray beds (Unit 5, $0.2 \mathrm{ft}$. thick) consists of grey fine sandstone with smallscale cross-bedding (Fig. 47.) Above this is a pebble conglomerate that fines upward into fine to medium grey sandstone (Unit 6,1.8 ft.). The sandstone is moderately sorted and cemented by quartz. The lower contact of Unit 6, as seen in the core and on the FMI log, is erosional in nature. Unit 7 (1.2 ft.) consists of a pebble conglomerate with ripples in sandstone at the top as seen on the FMI log. The basal contact is sharp in the core and appears to be erosional in the FMI. The conglomerate is abruptly overlain by thin beds of sandstone and shale. Unit $8(0.1 \mathrm{ft}$.) consists of a thin alternating sequence of pebble conglomerate and shale. Horizontal and sub horizontal burrows are observed in the shale beds, and a few small brachiopod impressions are present at the top of unit 8 . 


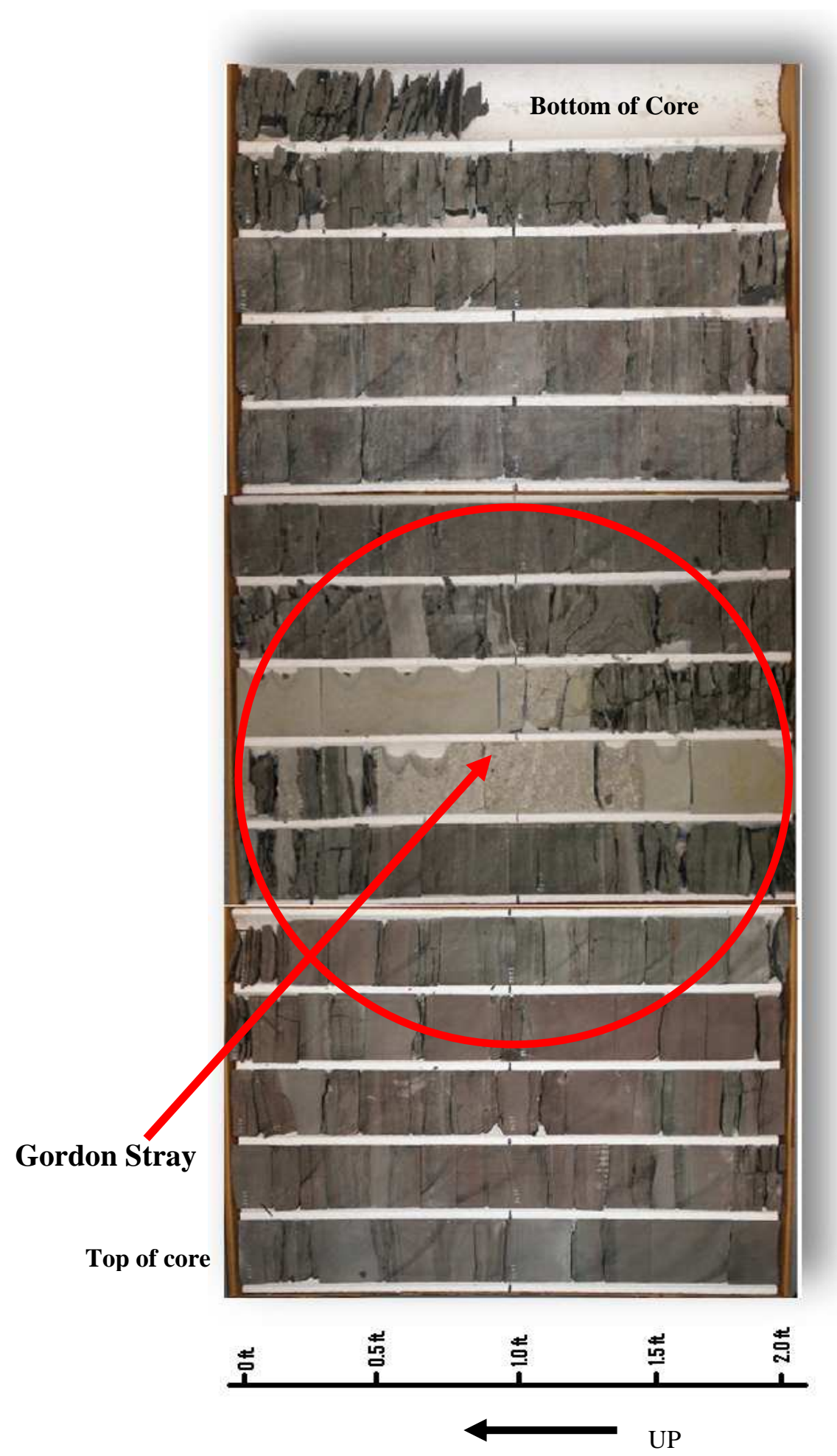

Figure 45. Photo of the portion of the core studied showing the Gordon Stray beds. The arrow indicates stratigraphic up. 


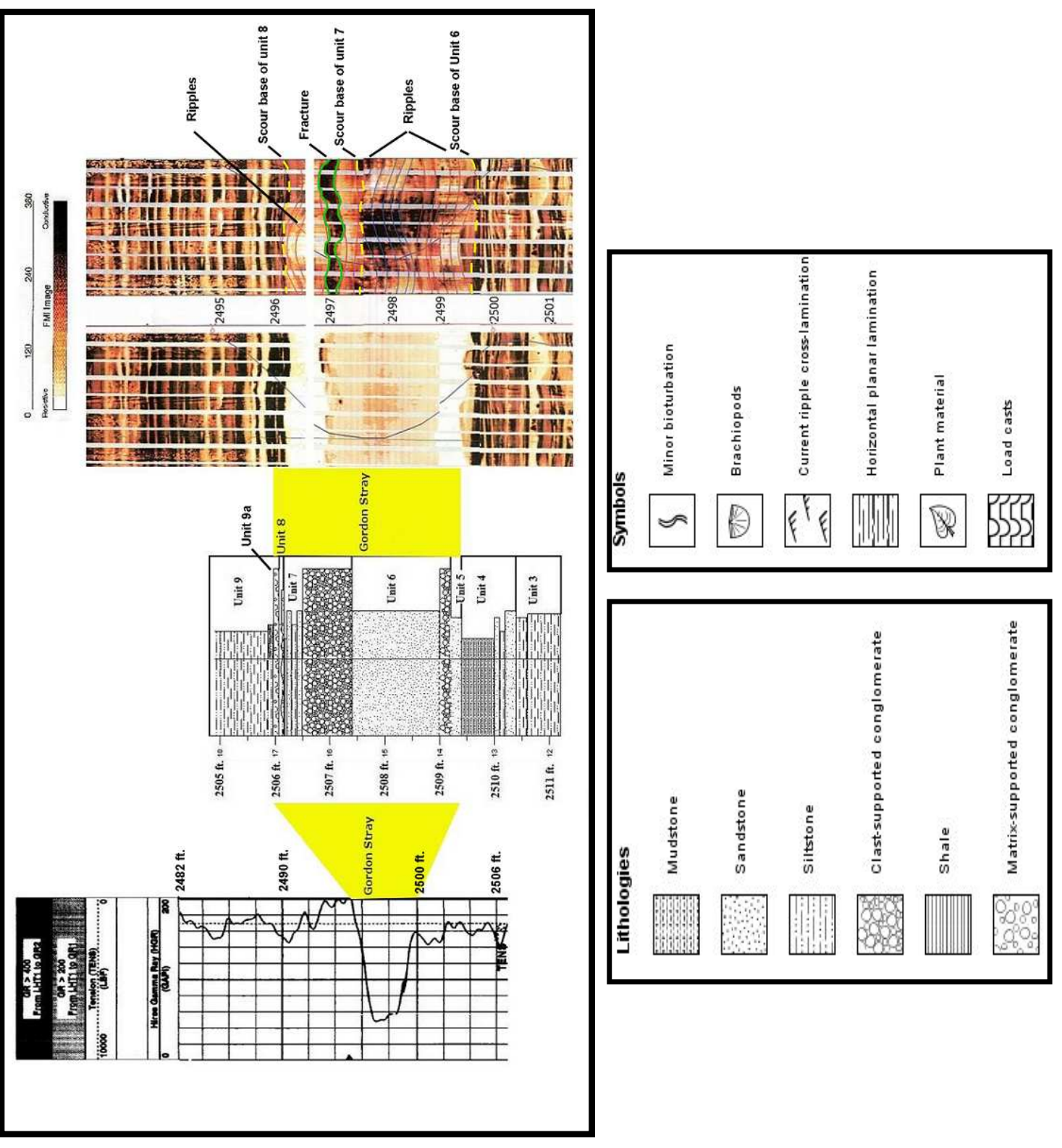

Figure 46. Gamma-ray log (left) and FMI log (right) compared to the stratigraphic column constructed for the Gordon Stray core. Core depth differs from log depth by +10 ft. 


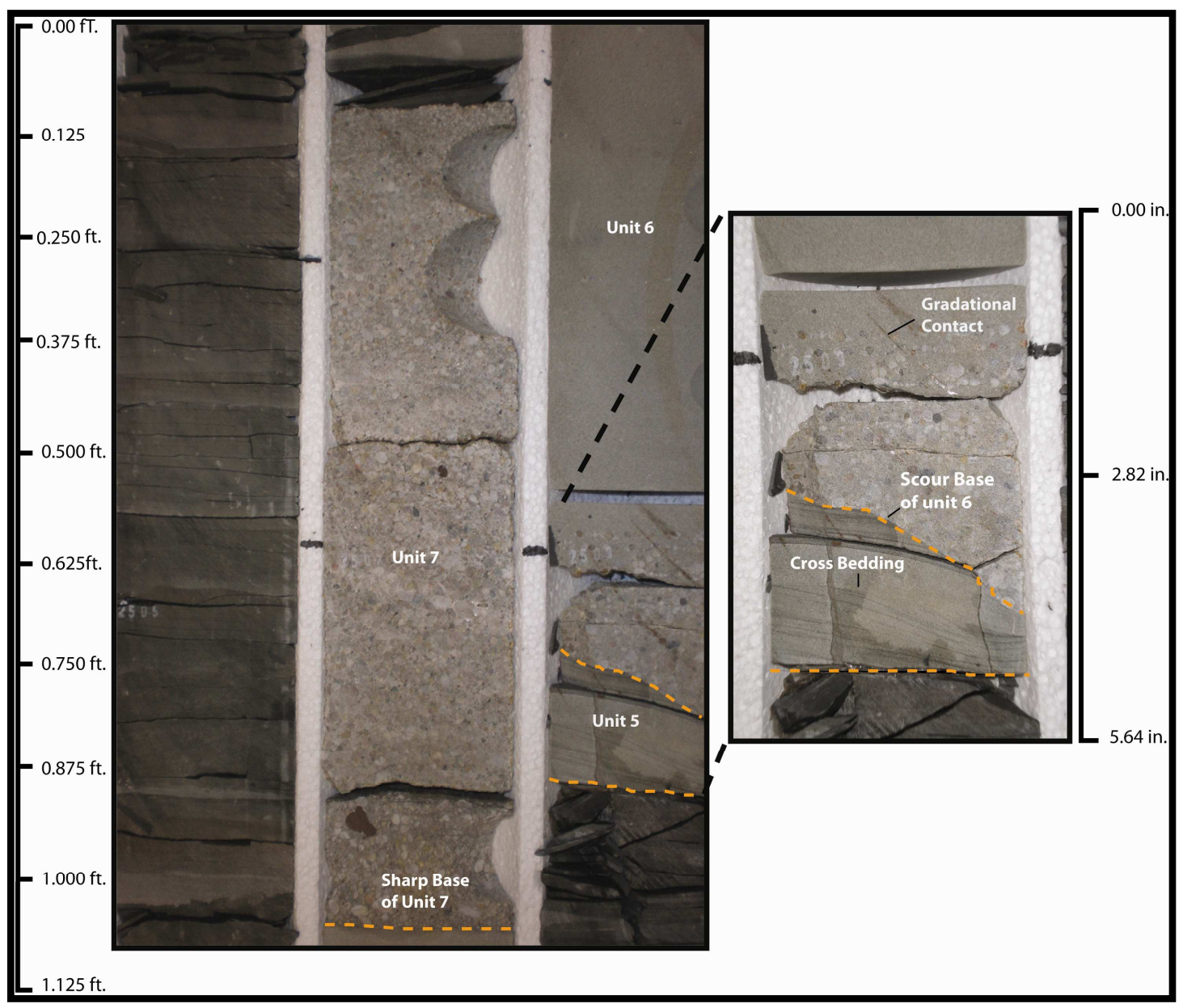

Figure 47. Gordon Stray core. Image shows erosional contact at the base of unit 6 , where conglomerate cuts into the grey fine sandstone of unit 5. Also shown is the gradational nature of unit 6 with conglomerate grading upward into sandstone. 
At the top of the Gordon Stray beds unit 9a consist of a relatively thin layer of matrixsupported conglomerate. The matrix consists of very fine lower sand, and the clasts are primarily rounded to sub-rounded quartz pebbles ranging in size from 3-4 mm.

\section{Fifth Beds}

Preliminary maps of the Fourth, Fifth, Thirty Foot (Nineveh), Fifty Foot and Gantz beds were constructed to aid in the regional analysis of the Gordon zone. Initially, tops and bottoms for these beds were picked to find the Gordon zone stratigraphically. Further into the project, it became apparent that preliminary isopach maps could easily be constructed to compare with the Gordon zone. Similar methods were used to describe preliminary maps as were used for maps of the Gordon zone.

The isopach map generated for the Fifth beds reveals several digitate thicks trending seaward (Fig. 48). The two most northerly thicks trend seaward and then turn to the south. Thicknesses of these bodies are 32-90 ft. Generally to the west, wells do not penetrate as deep as the Fifth beds stratigraphically; however, where wells do go deep enough, (e.g. southern Greene County), Fifth beds comprise thin sandstone bodies with a tongue-like gamma-ray pattern. In central Washington County, beds are thin and have a fining-up gamma-ray pattern. Near the Washington-Greene County border, beds are thin and tongue-like or display a blocky gamma-ray pattern. In southern Greene County, well logs show that beds consist of a blocky gamma-ray pattern. In the southernmost part of 


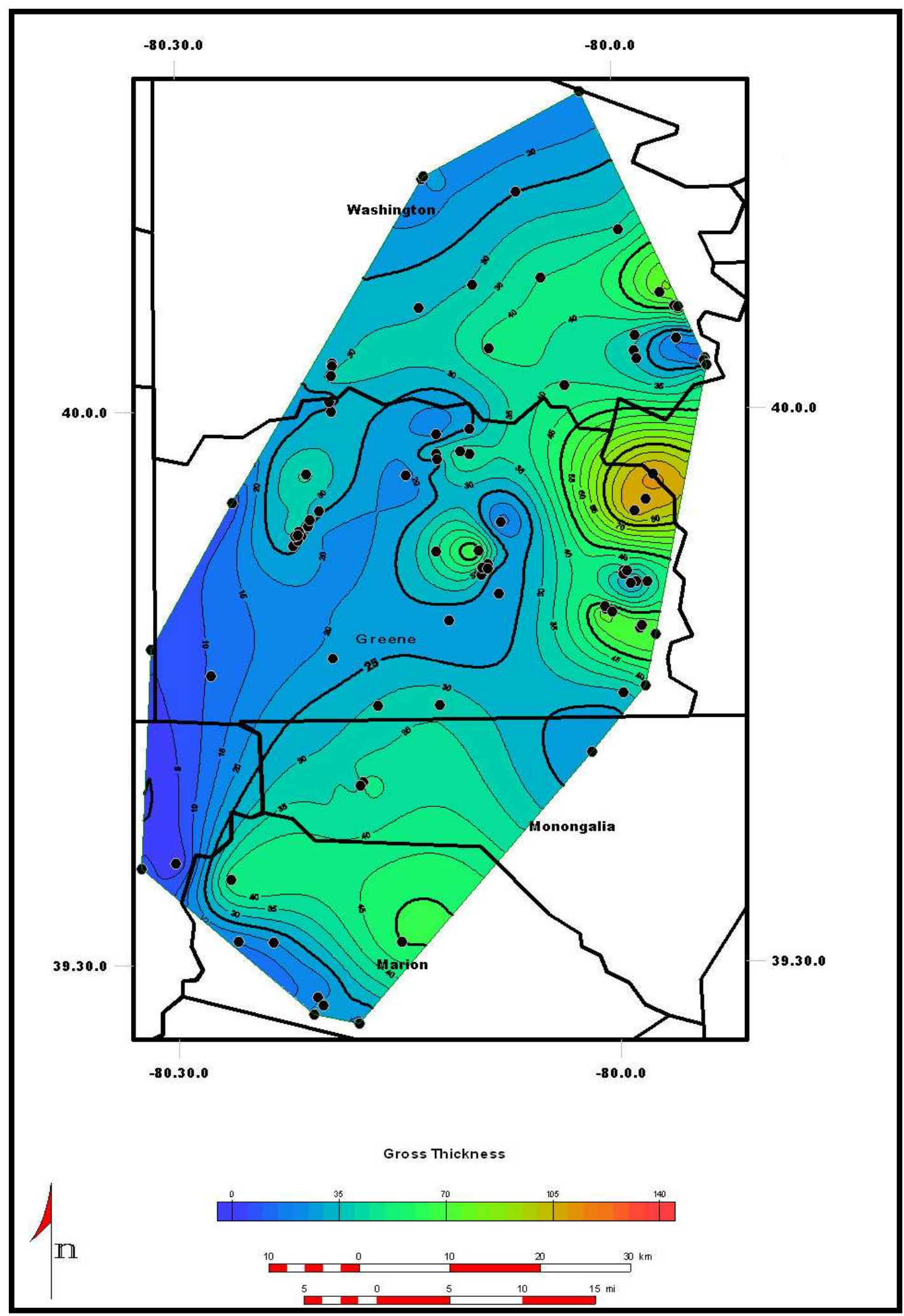

Figure 48. Isopach map of Fifth beds. Dots represent data points. Contour interval is $5 \mathrm{ft}$. 
the study area, Fifth beds are blocky on the gamma-ray logs. To the far east, beds consist of interbedded sandstone and shale.

A net sandstone map of 80 API or less was constructed for the Fifth beds to further aid in the analysis of sandstone distribution (Fig. 49). There are several similarities with the isopach map (Fig 48.). To the north in Washington County, there is one seaward trending sandstone body that turns to the south in the central part of the county. Thickness of this feature is as much as $35 \mathrm{ft}$. To the south, there is one pod-like sandstone body that obtains a thickness of $25 \mathrm{ft}$. In Marion County another seaward trending sandstone body is observed. Thickness of this feature is as much as $25 \mathrm{ft}$.

\section{Fourth Beds}

The isopach map generated for the Fourth beds reveals a sandstone distribution that is different from those of the Gordon zone (Fig 50). Fourth sandstone distribution is seaward-trending and digitate in nature. These features branch out like fingers from the easternmost portion of the study area to the central study area. Three distinct seawardtrending features are evident on the map. The first is located in Monongalia and Marion counties. This feature trends NNW and has a thickness of less than $45 \mathrm{ft}$. The second thick is in southern Greene County, and extends for approximately 20 miles. Thickness ranges from $40 \mathrm{ft}$. in the east to $60 \mathrm{ft}$. in the west. In northern Greene County and southern Washington County, yet another thick is evident. This thick trends 15 miles northwest and reaches a thickness of $70 \mathrm{ft}$. A fourth seaward trending thick is evident in the northern part of Washington County. It reaches a maximum thickness of $25 \mathrm{ft}$, , and extends northwest for roughly 10 miles. 


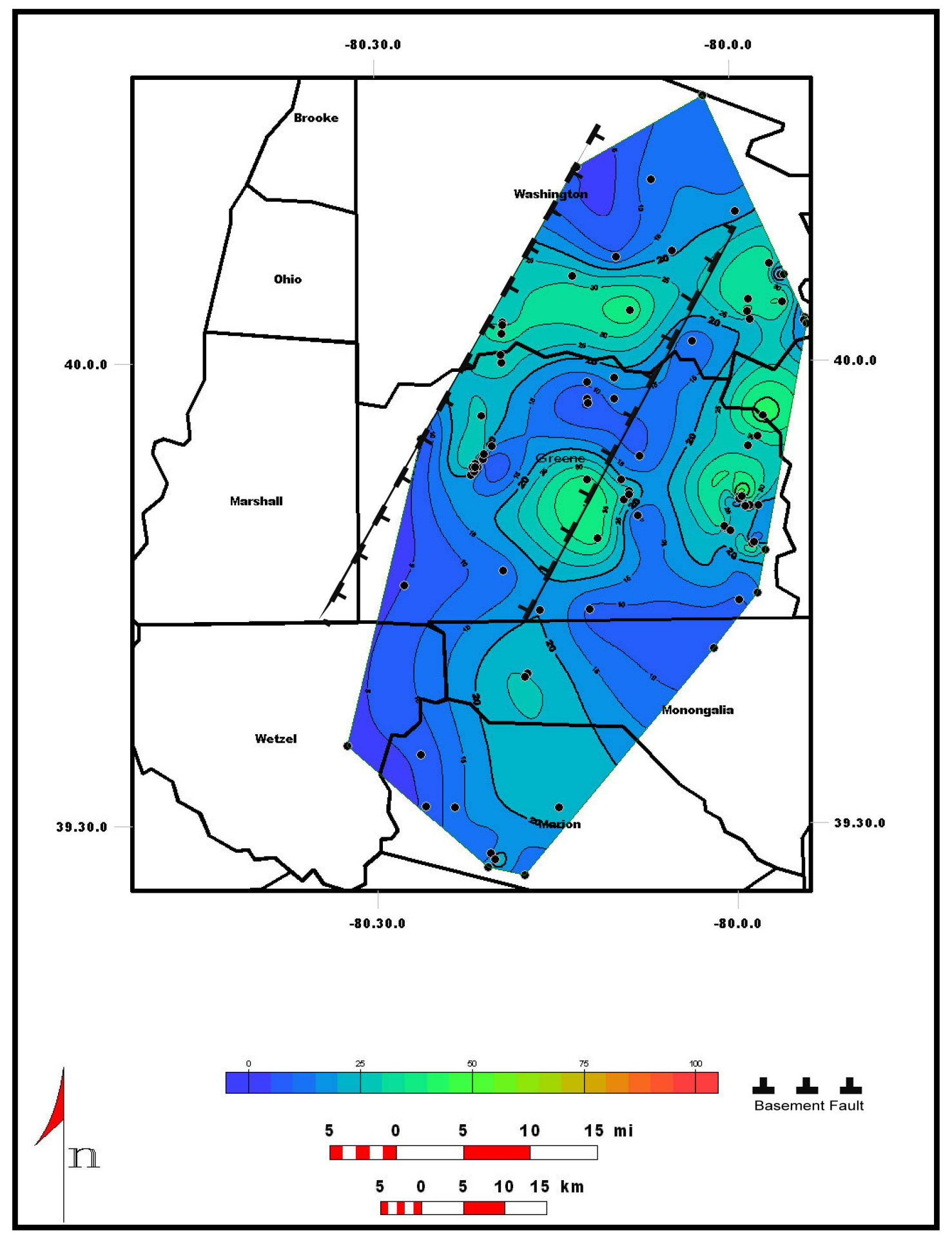

Figure 49. Net sandstone map of Fifth beds in the study area. Dots represent data points. Contour interval is $5 \mathrm{ft}$. Basement faults from Wagner (1977). 


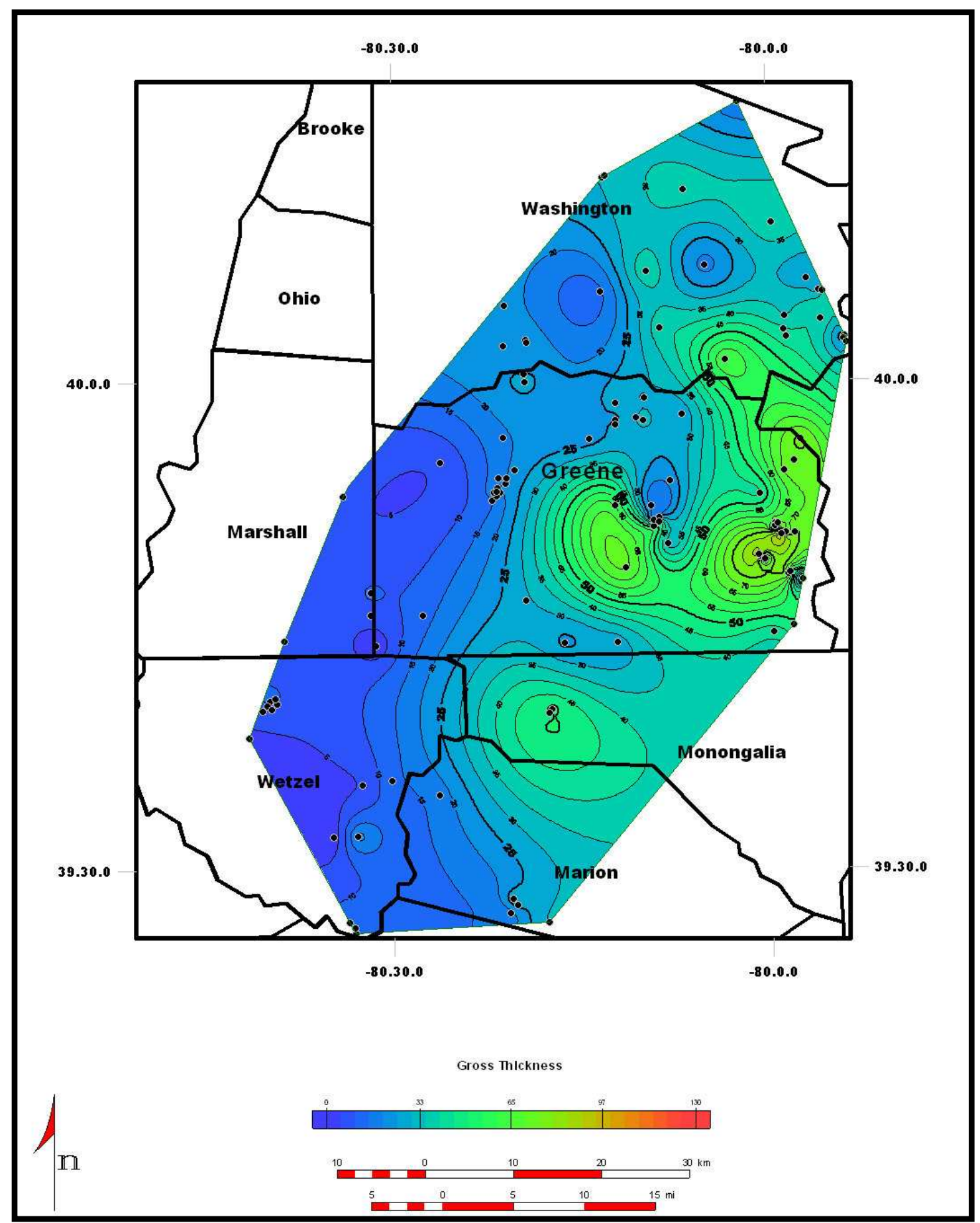

Figure 50. Isopach map of Fourth beds. Dots represent data points. Contour interval is $5 \mathrm{ft}$. 
A net sandstone map was generated for the Fourth beds to better recognize sandstone distribution (Fig. 51). To the North and to the south, shoreline trending thicks extend out across the study area like fingers. A third seaward trending sandstone body is evident across Greene County. This feature trends northwest and then turns due west. It extends for roughly 30 miles and acquires a thickness of as much as $20 \mathrm{ft}$. in central Greene County. Well logs show the beds to consist of clean sandstone bodies that display a blocky to tongue-like gamma-ray response. In southern Greene County beds consist of at least two stacked sandstone bodies. Some beds have a fining-up pattern whereas others coarsen upwards. In Marion County the gamma-ray log show beds to have a fork-like to blocky pattern and the unit generally consists of stacked sandstone.

\section{Thirty Foot Beds}

From the isopach map generated for the Thirty Foot beds there are two main trends that are apparent (Fig. 52). To the south, the trend strikes NNW across Marion and Monongalia Counties. The second trend strikes NNE across Greene and Washington Counties. In the cross-sections generated, Thirty Foot beds are thin and discontinuous on the westward side of the two main trends. Well logs show beds generally consist of thin, clean, sometimes discontinuous sandstones that display a blocky to tongue-like pattern. Beds rapidly thicken towards the central part of the study area. In Greene County, along the shoreline parallel thick, Thirty Foot beds consist of clean, multiple-stacked sandstone bodies displaying a blocky to fork-like gamma-ray pattern with an upper and lower sandstone body. To the east of the two main sandstone trends, Thirty Foot 


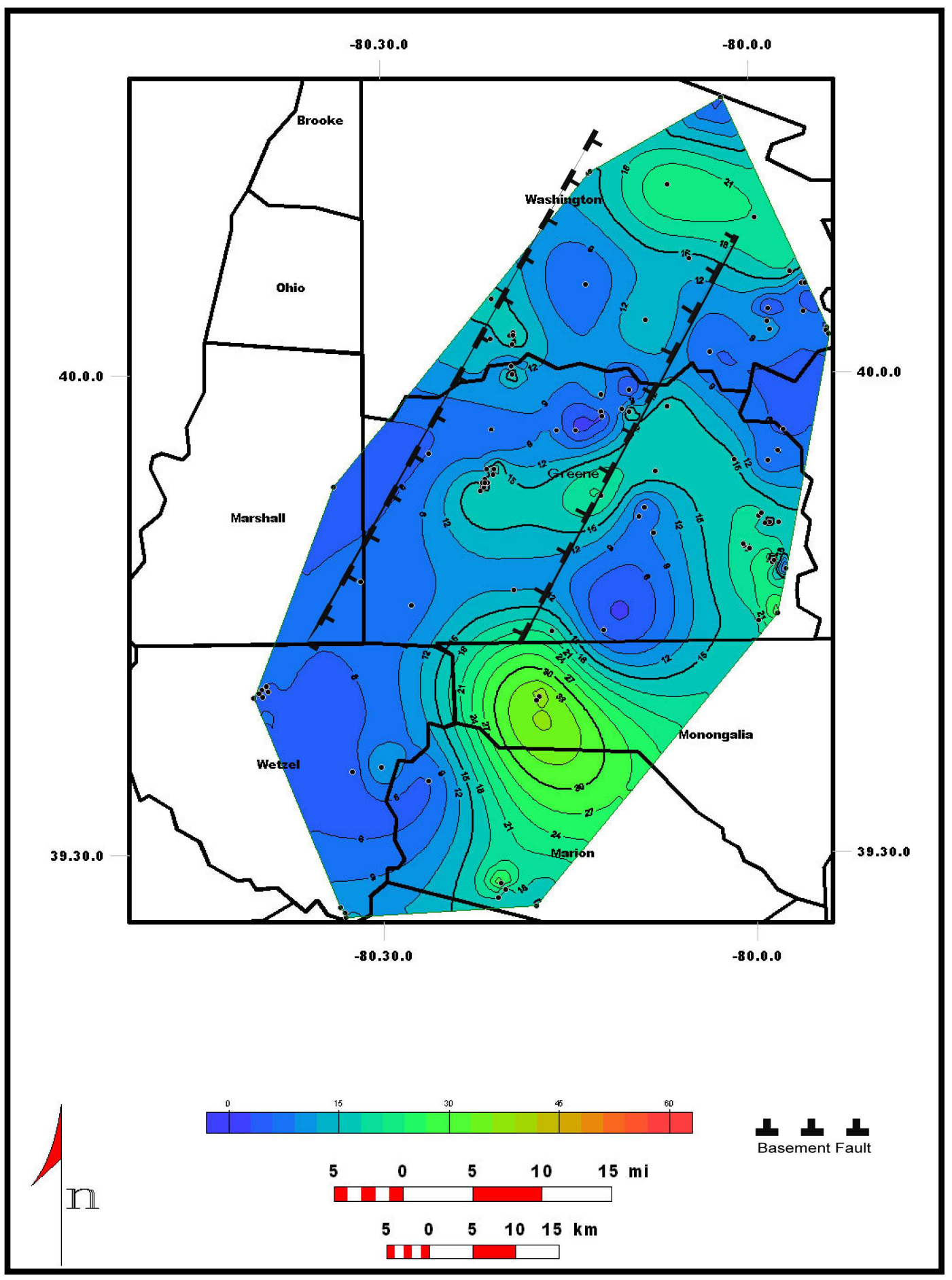

Figure 51. Net sandstone map of Fourth Beds in the study area. Dots represent data points. Contour interval is $3 \mathrm{ft}$. Basement faults from Wagner (1977). 


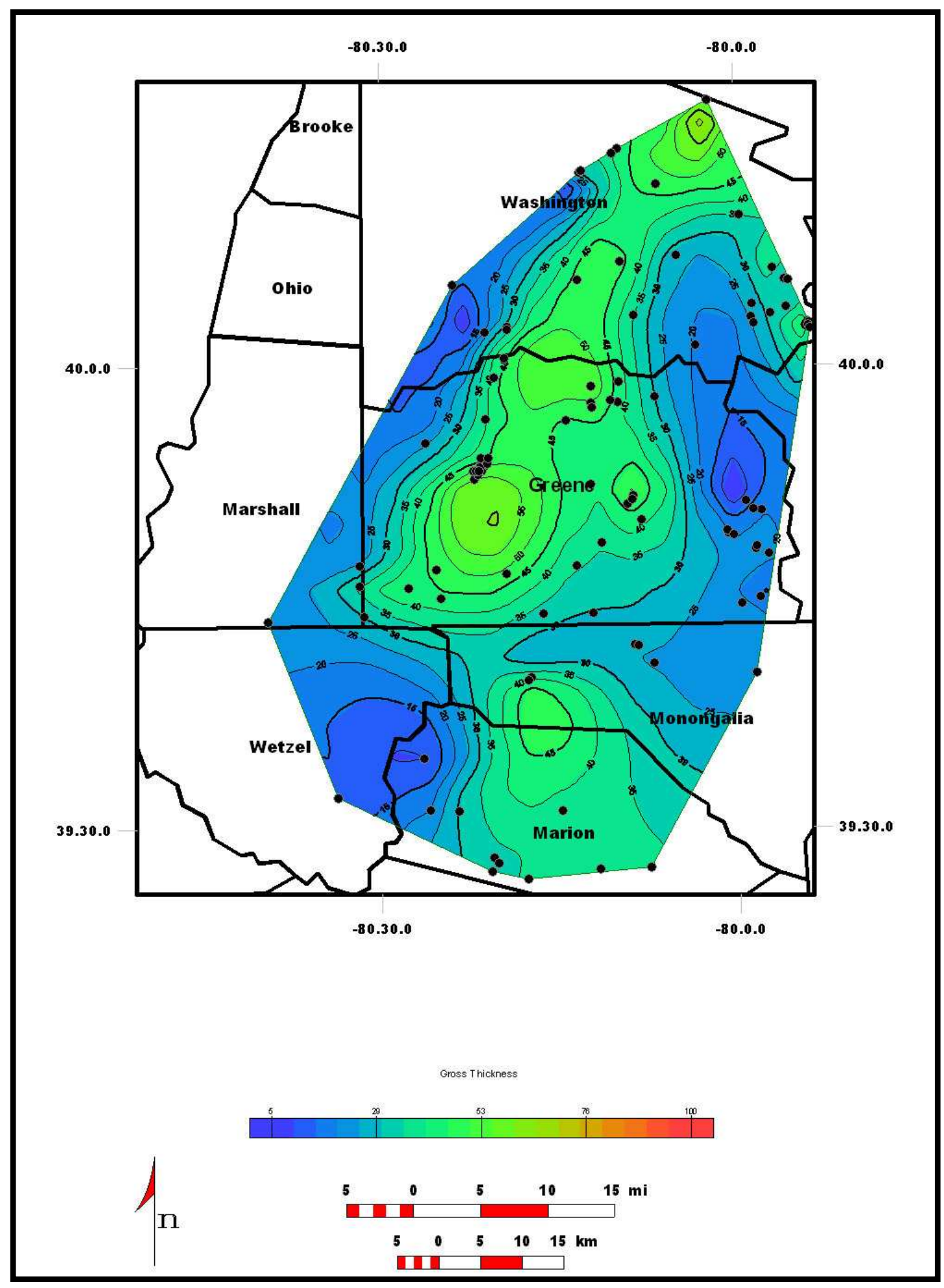

Figure 52. Isopach map of the Thirty Foot Beds. Black dots represent data points. Contour interval is $5 \mathrm{ft}$. 
beds gradually decrease in thickness. In Washington County, sandstone beds become interbedded with shale.

A net sandstone map of the Thirty Foot beds was constructed to better observe the sandstone distribution throughout the study area (Fig. 53). Comparing the net sandstone map to the isopach map yields several similarities including a north-east trend situated across Greene and Washington Counties. A second sandstone body which is less defined in the isopach map, but is better observed in the net sandstone map is situated to the north of the main trend and is located in northern Washington County. Differences between the net sandstone map and the isopach map obviously include thickness but other differences include pod-like sandstone thicks situated in Marion and Monongalia counties. These sandstone bodies reach a maximum thickness of $35 \mathrm{ft}$. The maximum thickness of the main north-east trend across Greene and southern Washington County reaches $35 \mathrm{ft}$., and the thick to the north in northern Washington County reaches a maximum thickness of 28 ft.

\section{Fifty Foot Beds}

From the isopach map of Fifty Foot beds (Fig. 54), there is one sinuous sandstone body striking approximately due north that runs through Greene and Washington counties. The sandstone thick broadens to the south and turns to the south east across Monongalia and Marion counties and has a maximum thickness of $70 \mathrm{ft}$. in central Greene and Washington counties. West of this feature, Fifty Foot beds thin and pinch out. On the eastern side, there are at least two linear features trending perpendicular to the shoreline in the northern and southern parts of Greene County, Pennsylvania. Average thickness of these features is $90 \mathrm{ft}$., and the length is 5-10 miles from east to west. 


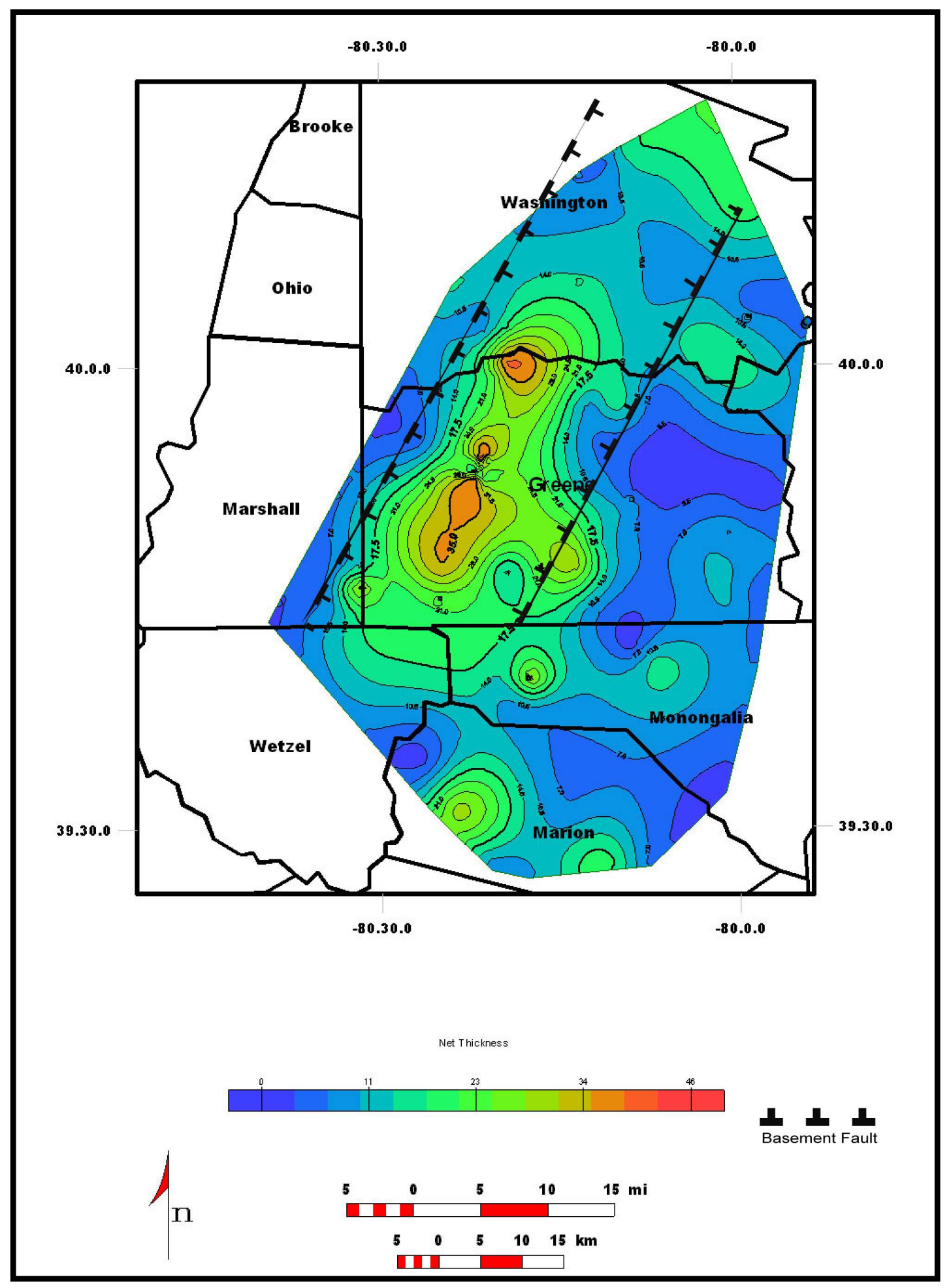

Figure 53. Net sandstone map of the Thirty Foot beds. Dots represent data points. Contour interval is $3.5 \mathrm{ft}$. 


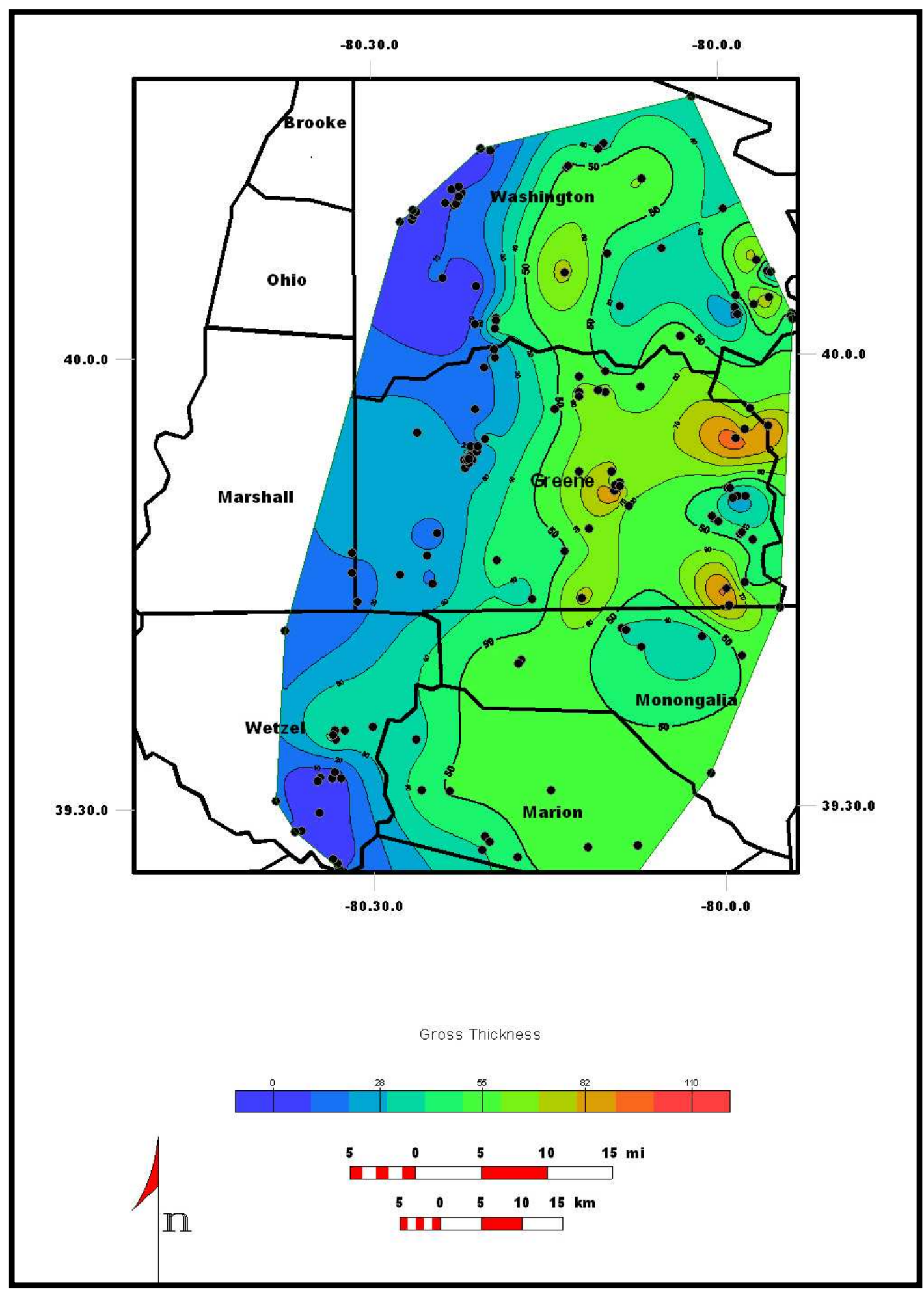

Figure 54. Isopach map of Fifty Foot beds. Dots represent data points. Contour Interval is $10 \mathrm{ft}$. 
To the west of the main sandstone body, gamma-ray logs show Fifty Foot beds are thin and display a tongue-like pattern. A rapid increase in thickness occurs towards the central part of the study area. Here, Fifty Foot beds display a blocky to concave gamma-ray pattern. To the east, the thickness of the Fifty Foot beds is irregular and shale interbeds become more prominent. Beds gradually thicken and change from single blocky clean sandstone in central Greene County, to multiple stacked sandstone bodies to the east. In the southern part of the county, beds remain generally of the same thickness, but the gamma-ray response changes from a clean, concave pattern to interbedded sandstone and shale that consists of a variety of gamma-ray patterns including seriated, coarsening upward, and in some cases blocky. In Marion County, well logs show the Fifty Foot beds to consist of multiple stacked sandstone bodies separated by minor shale breaks.

A net sandstone map was constructed to better recognize sandstone distribution of the Fifty Foot beds (Fig. 55). Comparing the isopach map to the net sandstone map, there are noticeable differences in thickness but the overall trend is the same. The net sandstone map reveals one shoreline-parallel trend that obtains a thickness of up to $65 \mathrm{ft}$. in Washington and Greene counties. To the far east in southern Washington County, the net sandstone map reveals a sandstone thick that meanders to the south and then turns north across northern Greene County. To the south, in Marion and Monongalia counties there is one broad feature that has a thickness of $45 \mathrm{ft}$. To the north east of this, one dip trending sandstone body is observed with a thickness of $45 \mathrm{ft}$. 


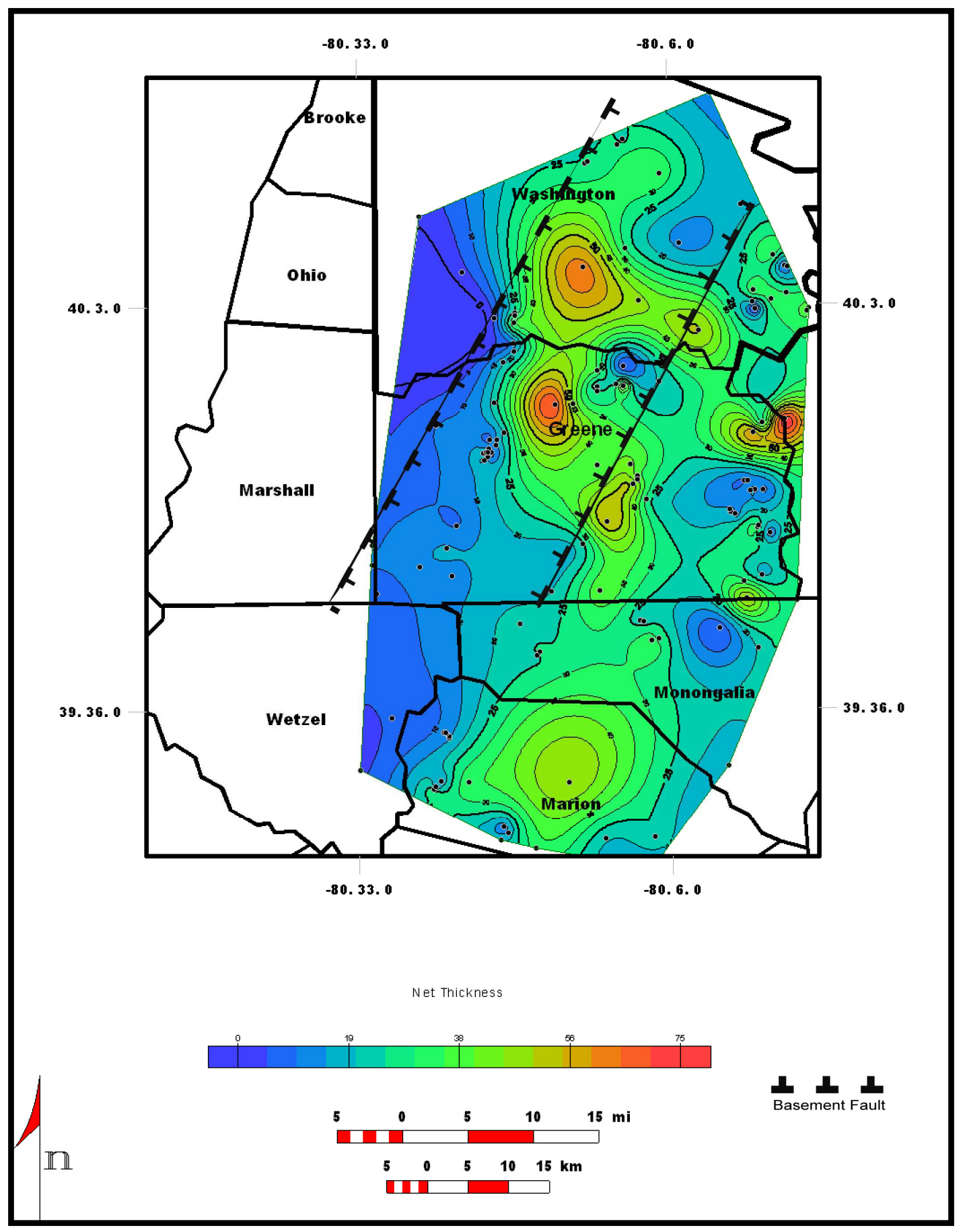

Figure 55. Net sandstone map of the Fifty Foot beds. Dots represent data points. Contour interval is $5 \mathrm{ft}$. 


\section{Gantz Beds}

An isopach map of the Gantz beds was constructed to analyze and define sandstone geometry and trend (Fig. 56). On the map two pod-like features can be seen in northern Washington County with thicknesses of up to $50 \mathrm{ft}$. To the south in Marion County another pod-like feature exist with a maximum thickness of $45 \mathrm{ft}$. In the east across Washington, Greene, and Monongalia counties, one shoreline-parallel thick meanders and then turns to the NE.

A net sandstone map of the Gantz beds was constructed to better characterize this trend (Fig. 57). From this map, there are a variety of similarities including a sandstone thick to the south in Marion County. Well logs here show Gantz beds consist of stacked to massive clean sandstone with a blocky to concave gamma-ray response. To the east, one north-south thick is apparent. Well logs show Gantz beds here consist of a seriated gamma-ray response displaying a thick sequence of alternating clean sandstone and shale. This trend turns to the NE in Monongalia and Greene counties where well logs show that the beds consist of a blocky gamma-ray response showing clean stacked sandstone. To the north in Washington and Greene counties, the net sandstone map shows one shoreline-parallel thick with well logs displaying a massive clean sandstone with a blocky to concave gamma-ray response. To the west, Gantz beds thin and gradually pinch out. Well $\operatorname{logs}$ there show beds consist of a single thin tongue of clean sandstone. 


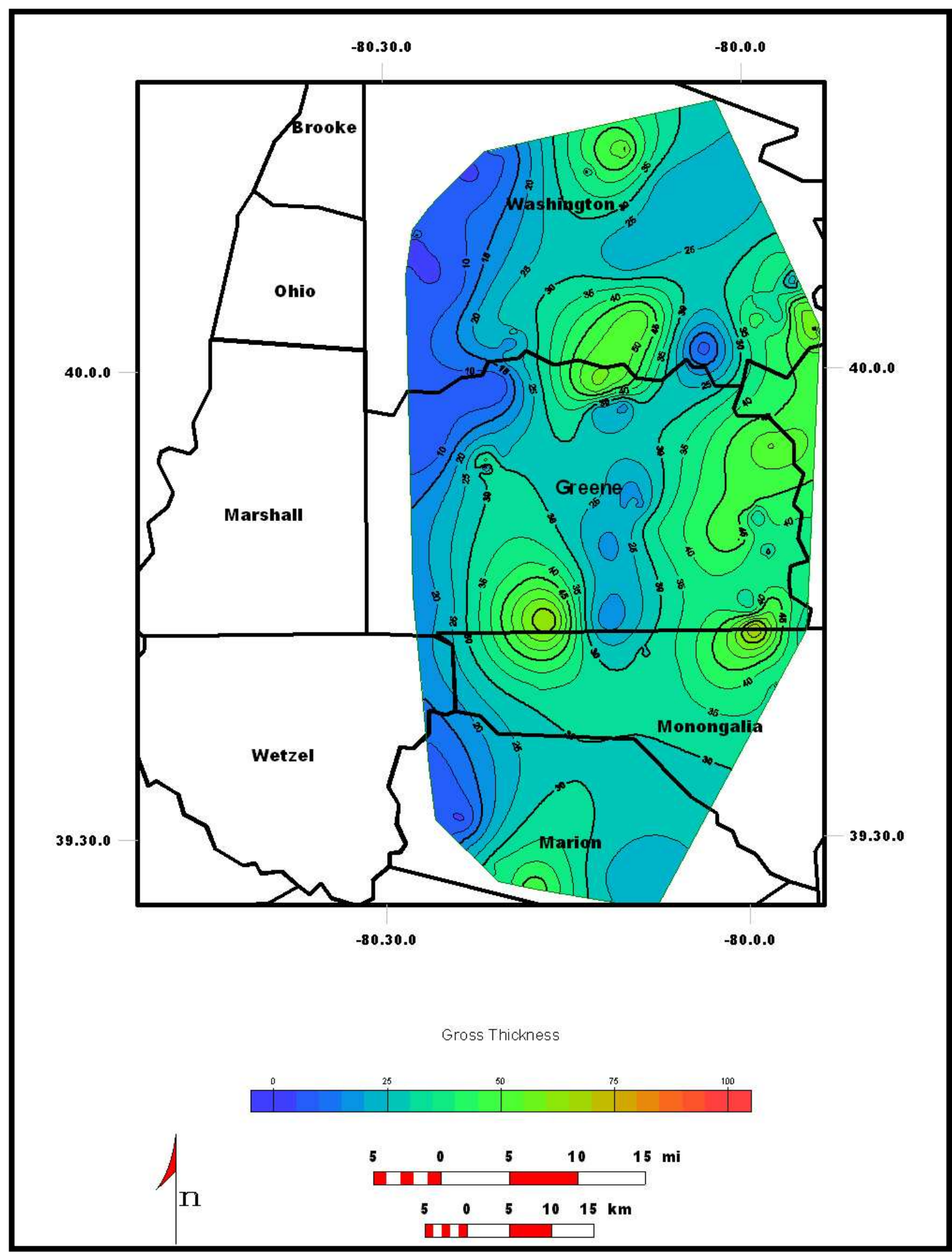

Figure 56. Isopach map of Gantz beds. Dots represent data points. Contour interval is $5 \mathrm{ft}$. 


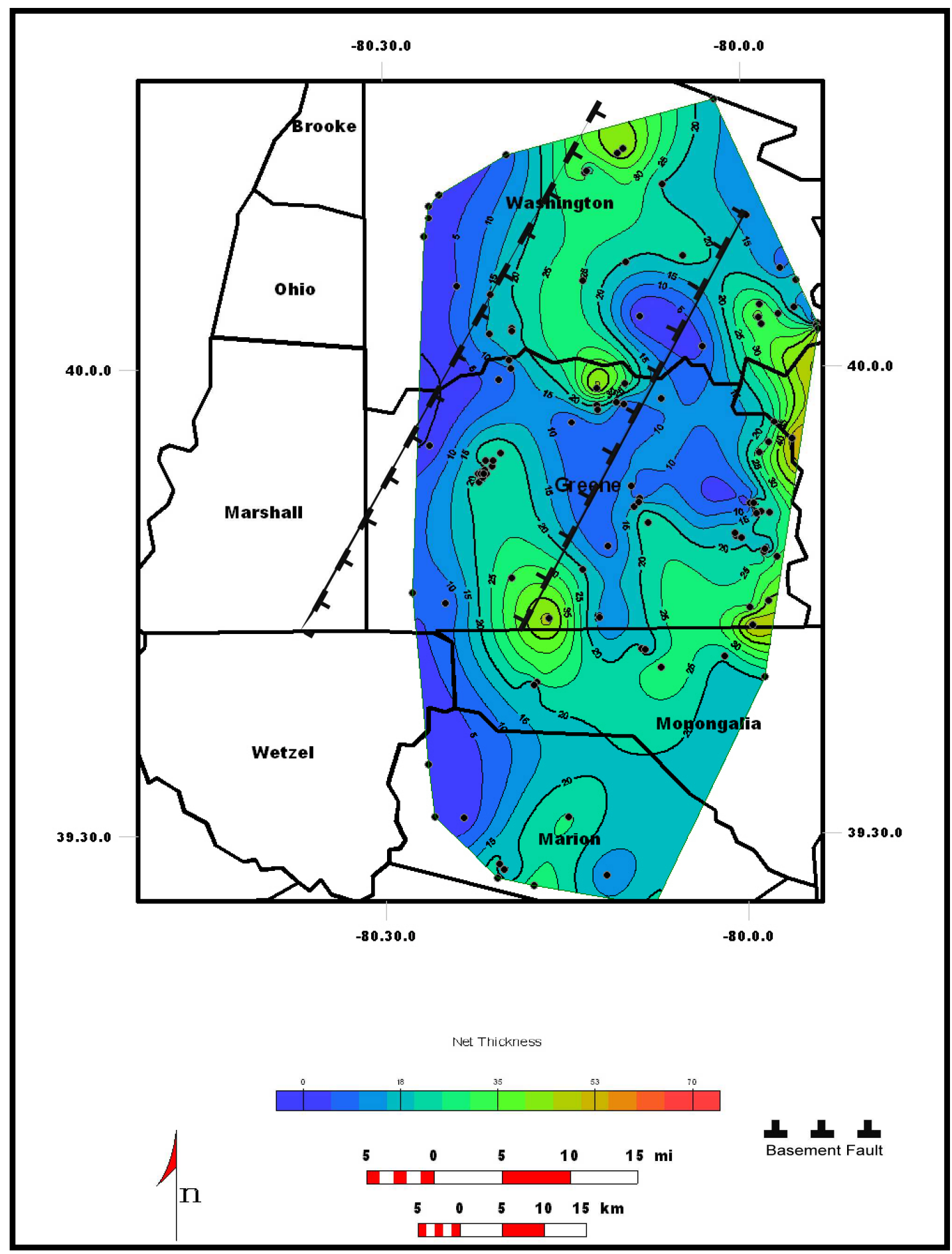

Figure 57. Net sandstone map of the Gantz beds. Dots represent data points. Contour interval is $5 \mathrm{ft}$. 


\section{FACIES ANALYSIS}

Facies analysis was carried out based primarily on sandstone distribution and geometry. Other workers, including Boswell and Jewell (1988) and McBride and Smosna (2005), followed similar methods. Observations from the Gordon Stray core were also utilized. Gamma-ray log signatures were incorporated for a more complete facies interpretation. The patterns observed in well-log curves have long been used for facies interpretation due to their similarity to grain size successions (Cant, 1992). Gamma-ray curves reflect the amount of clay with absorbed radioactive elements, and thus inferences can be made on the vertical distribution of sandstone and shale. However, no gamma-ray curve pattern alone is unique or diagnostic of any one depositional environment but is merely suggestive (Cant, 1992) (Fig. 58). Ideally curve shape analysis works best when compared to core or cuttings from the well bore.

In my analyses, gamma-ray patterns observed in well logs were compared to the sandstone distribution and geometry to give further insight into facies. A variety of gamma-ray log patterns were recognized throughout the study area. These patterns include blocky, coarsening upwards, fining upwards, concave, tongue-like, fork-like, and spiky (Fig. 59). A shoreline-parallel sandstone geometry along with a variety of well log patterns, including blocky, concave, fining upwards sequence, coarsening upwards sequence, or forked patterns, suggest a barrier-island facies. The sand body consists of one thick sandstone or less frequently, vertically stacked sandstone separated by thin shale. The positioning of sandstone on the landward or seaward side of the main barrier island trend, along with a variety of well log signatures, suggests additional sub-facies. In the lagoon landward of the barrier island, well logs show a spiky gamma-ray response 


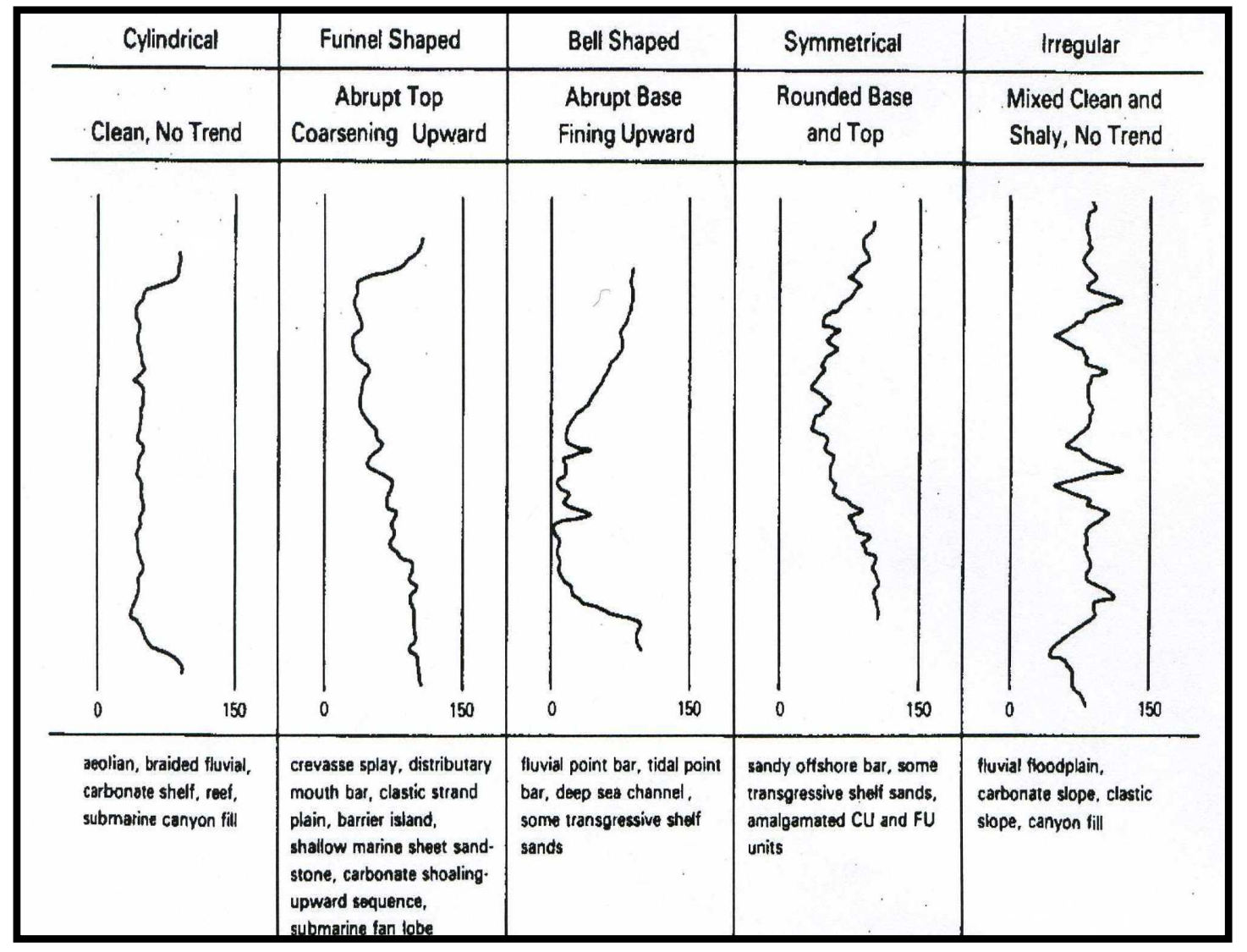

Figure 58. Common gamma-ray patterns and their associated possible facies. From Cant (1991). 


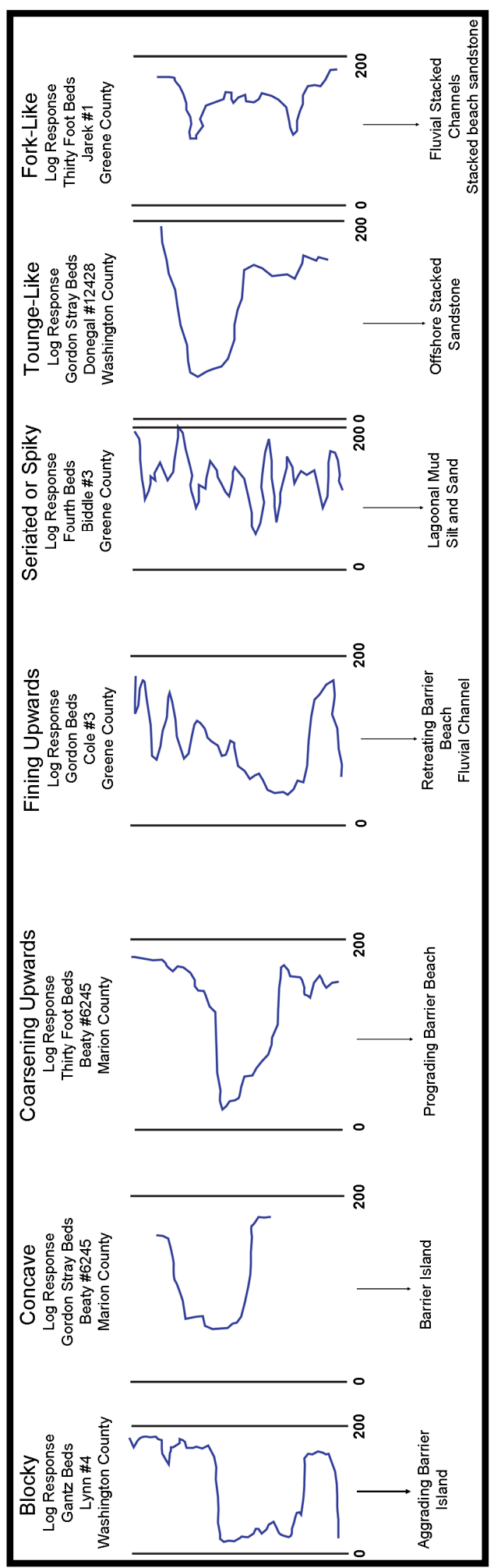

Figure 59. Examples of gamma ray patterns from wells in the study area, and possible depositional environments as determined for this study. 
indicating an interbedding of siltstone, shaly sandstone or clean sandstone. Seward of the barrier island, the stacking of thin sandstone beds produce a tongue-like gamma-ray response. Fluvial facies are suggested by sandstone bodies that are distributed perpendicular to the shoreline and consist of clean sandstone displaying gamma-ray patterns such as fining upwards or forked.

\section{Gordon Beds}

The geometry and linear trend observed in the net-sandstone map of the Gordon beds suggest a barrier-island facies (Fig. 31). The blocky to coarsening upward gammaray pattern seen in well logs supports this interpretation. Barrier island systems may be composed of numerous sub-facies including tidal channels, tidal deltas, and washover fans depending on wave energy, sediment supply, and tidal range (Davis, 1994) (Fig.60). For example, under microtidal conditions, barrier islands tend to be long and narrow, with poorly developed tidal channels and tidal deltas. Due to the lack of channels, storm surges tend to overtop the barrier, washing dune sand into the lagoon and forming sheetlike sandstone bodies known as washover fans (Gerald 1992). Alternatively, under mesotidal conditions barrier islands tend to be shorter and stunted due to the high tidal range. Tidal channels and tidal deltas are well developed (Gerald 1992).

Net sandstone maps produced by Boswell et al. (1987) show a similar geometry and trend for the Gordon beds in northern West Virginia which they interpreted to be a barrier-island complex. From the net-sandstone map produced for this study (Fig. 31), a paleogeographic reconstruction of Gordon deposition was generated (Fig. 61). There was a single barrier island system trending NNE across the study area. 


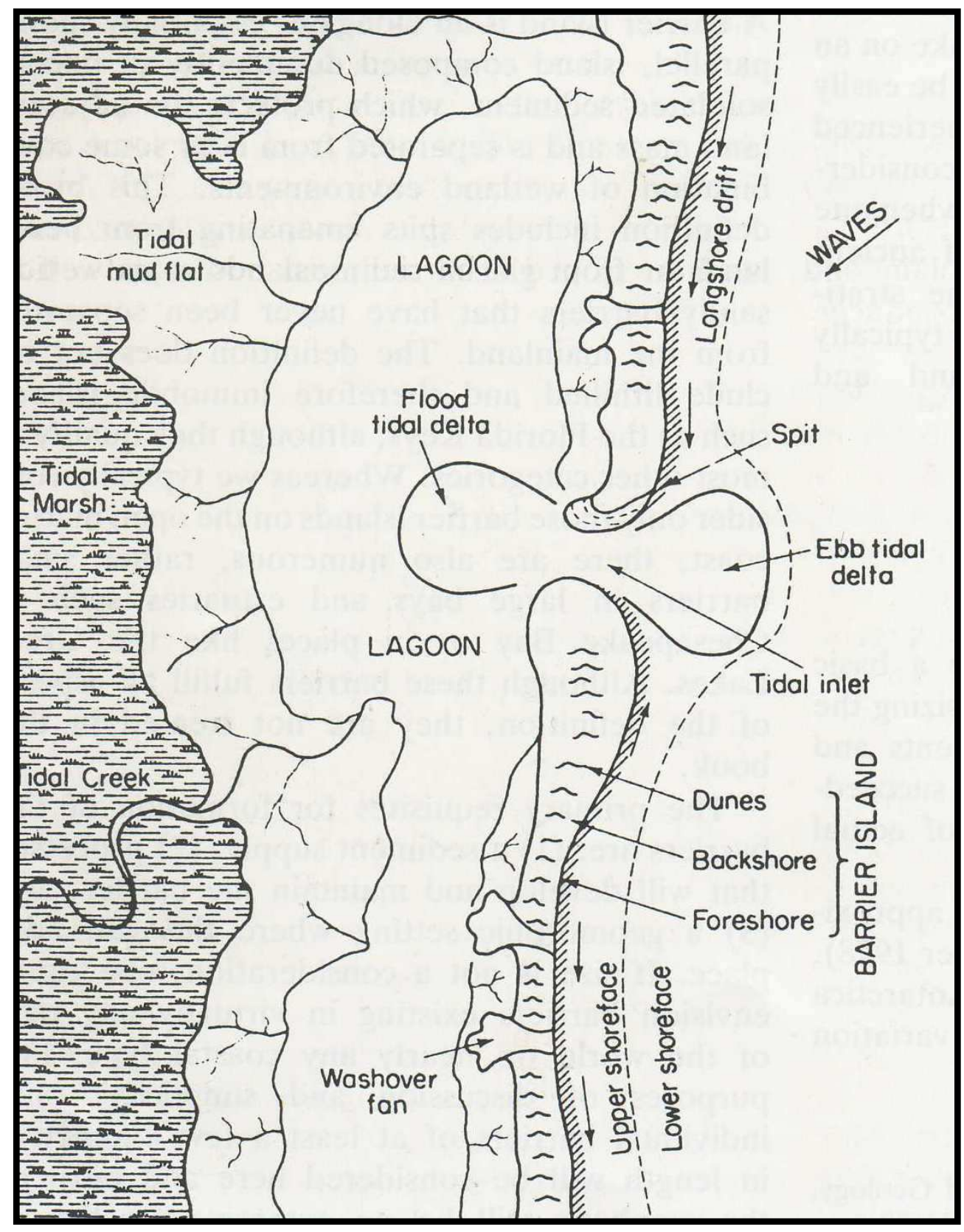

Figure 60. Sketch showing major sub-environments of a barrier island system. From Davis (1994) 


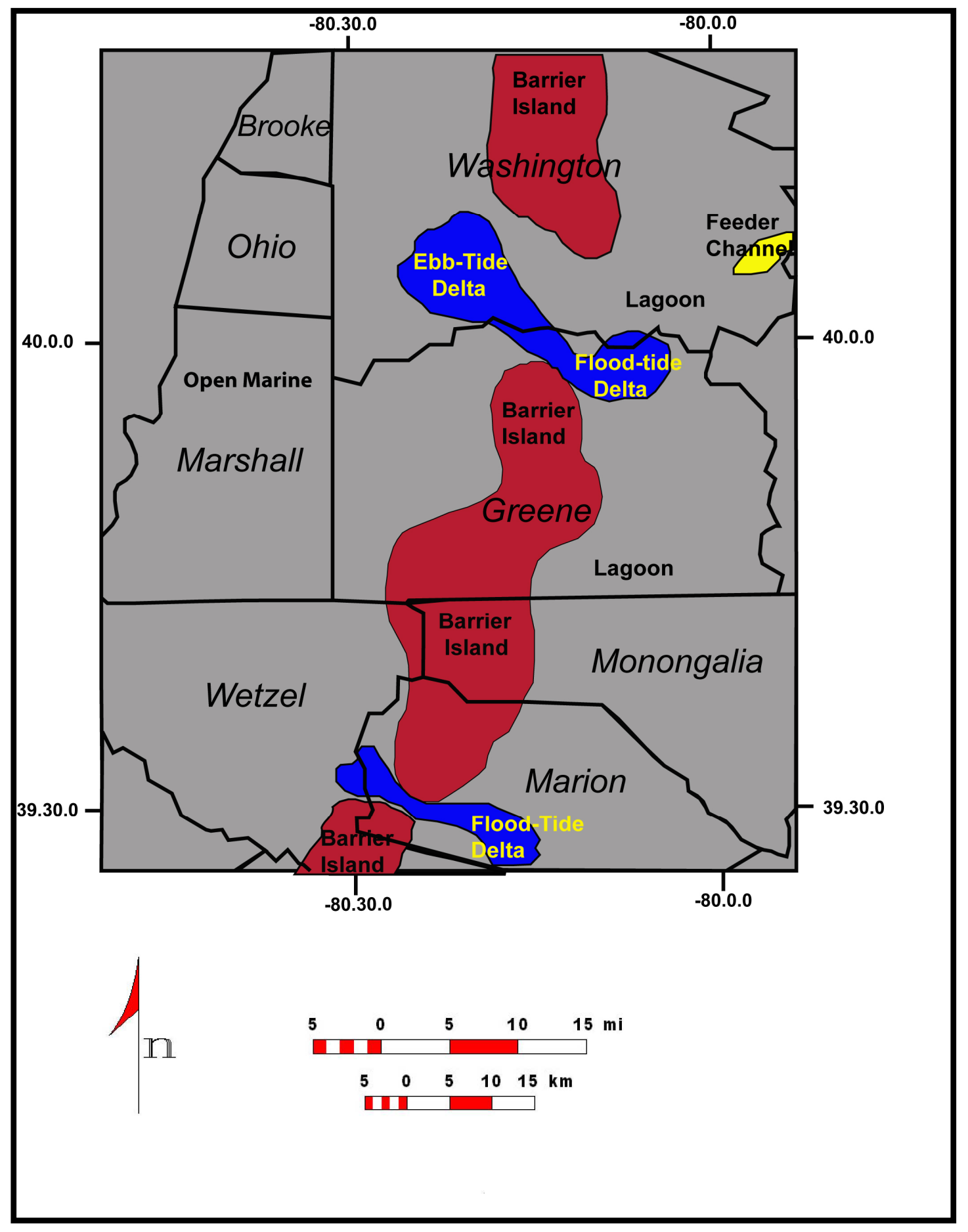

Figure 61. Paleogeographic reconstruction of the Gordon beds. 
In southern Washington County, a tidal inlet is suggested by sandstone geometries that show ebb-tidal delta development to the west and flood tidal delta development to the east. Cross section A-A' (Fig. 41) suggests that the barrier in Washington County was aggrading over time and not migrating laterally. Also suggested by the net sandstone map and the fining upwards gamma-ray pattern is a possible feeder channel to the east. A second tidal channel with a flood tide delta is suggested by the net sandstone map to the south in Marion County. Although not readily apparent on the net sandstone map (Fig. 31), cross-section C-C' (Fig. 32) suggests a series of washover sheets in southern Greene County behind the barrier. To the south in Wetzel and Marion Counties, D-D” (Fig. 34) shows the Gordon barrier agrading. Also suggested by the cross-section D-D” is a series of washover sheets located behind the barrier much like C-C' in Greene County. Seaward of the barrier islands the net sandstone map and cross-section D-D" suggest sheet-like sandstone in Wetzel County.

\section{Gordon Stray Beds}

From the net-sandstone map (Fig. 36) the linear geometry of the Gordon Stray beds suggest a barrier island complex similar to the Gordon beds. The blocky to concave gamma-ray pattern observed in well logs supports this interpretation. Previous studies in northern West Virginia by Boswell et al. (1987) and McBride and Smosna (2005) also interpreted Gordon Stray beds as being a barrier-island system with a similar sandstone geometry and trend (Figs. 12 and 19).

A paleogeographic reconstruction of Gordon Stray beds shows one shorelineparallel trend generally oriented northeast across the study area (Fig. 62). In Wetzel County, there is a dog-leg bend trending south west. Three tidal channels consisting of 


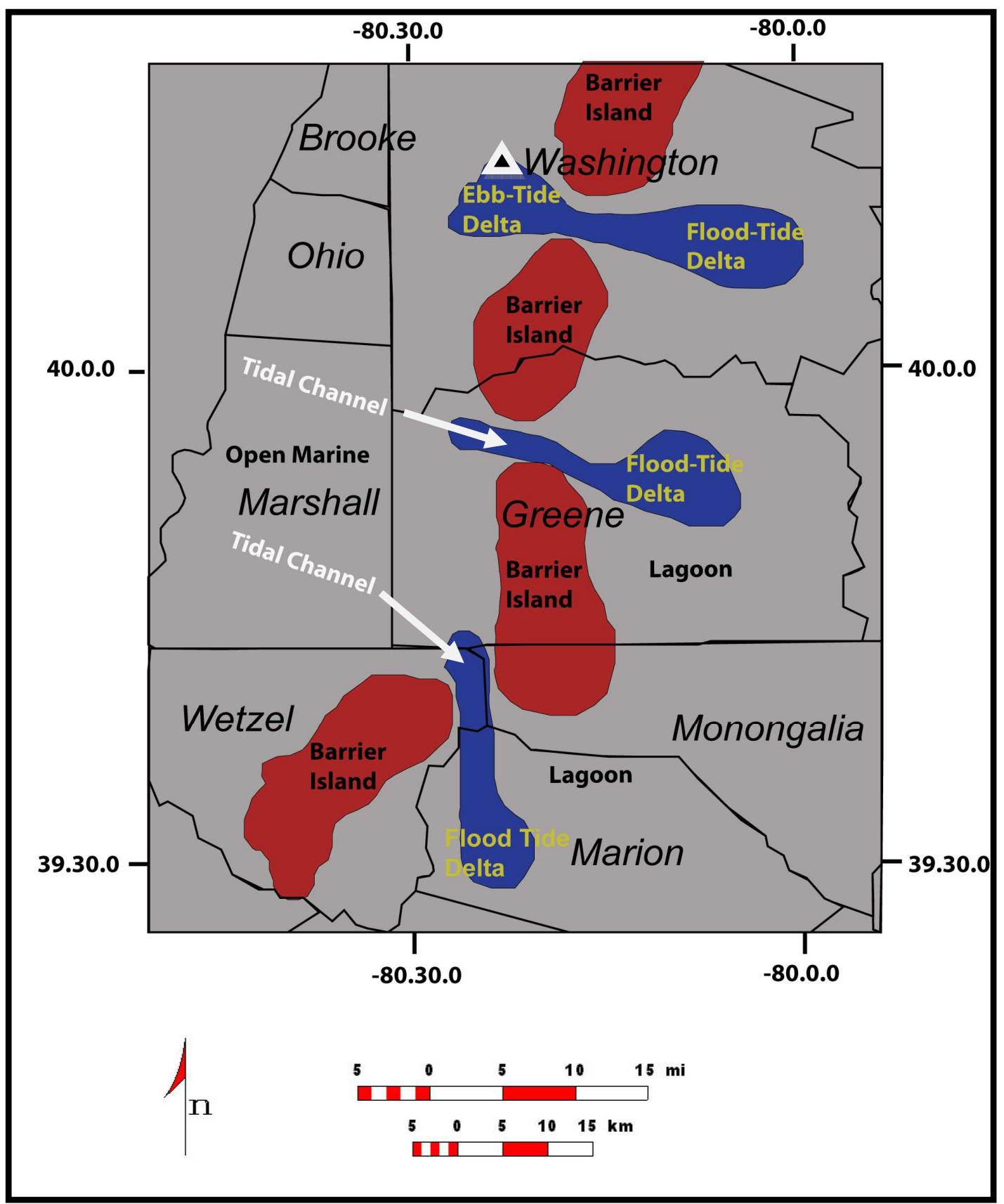

Figure 62. Paleogeographic reconstruction of Gordon Stray beds. Triangle represents core location. 
thin sandstone beds cut across the barrier system. On the landward side of this trend there are three pod-like and semi-circular thicks. The position and geometry of these features suggest flood-tide delta sub-facies.

A core study was conducted paying close attention to rock type, texture, bedding, sedimentary structures, and fossil content (Fig. 47). In the core, there are at least two stacked tidal channels with a channel lag at the base grading upward to fine sandstone. Further indication of channel facies include a scour surface found at the base of units 6,7 , and 8 and small-scale cross-bedding. The positioning of the deposits in Washington County on the seaward side of the barrier island and brachiopod fossils found near the top of the Gordon Stray unit suggest these channels were deposited in an ebb-tide delta environment.

\section{Fifth Beds}

From the isopach map generated for the Fifth beds (Fig. 48), the sandstone distribution and geometry suggest deposition occurred in a fluvial-dominated delta environment with some wave influence. In northern West Virginia, Boswell and Jewell (1988) also interpreted the Fifth beds as being deposited in a fluvial deltaic environment with a lobate shoreline. Deltas are characterized by a river-dominated zone known as the delta plain, a zone of interaction between fluvial and basinal processes known as the delta front, and an offshore zone of deposition from suspension and sediment-gravity flow, known as the prodelta (Fig. 63).

Barrier island deltaic systems, such as the Gordon and Gordon Stray, are considered to be destructive systems. 


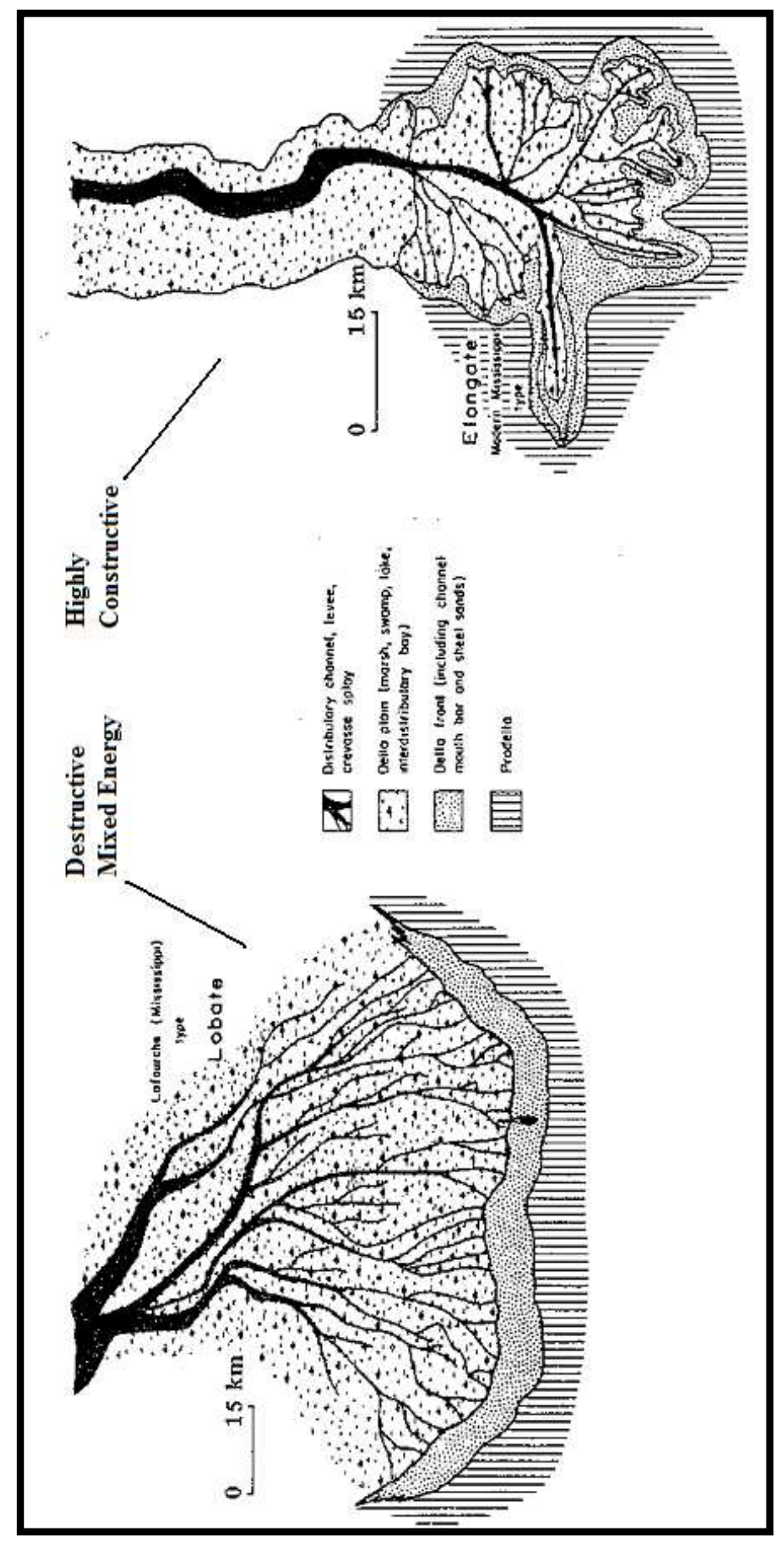

Figure 63. Illustration of a mixed (left) and a fluvial (right) dominated delta environment. The fluvial dominated delta on the right represents the modern Mississippi delta. Modified from Davis (1983). 
Sediment supply was relatively low and the shoreline geometry was primarily dictated by wave energy. Waves reworked sediment into smooth straight shorelines (Davis, 1983). Fluvial-dominated delta-front environments, on the other hand, are defined by high sediment supply creating a digitate to lobate shoreline geometry. These types of deltas are known as constructive deltas (Davis, 1983). Constructive deltas contain a broad, well developed drainage system which supplies a large amount of sediment, and occurs on extensive shallow shelves where wave energy is low.

The net sandstone map produced for the Fifth beds show three distinct distributaries with a barrier island developed to the north. This suggests that the delta system during the time the Fifth beds were deposited was affected by a combination (mixed energy) of fluvial dominating processes and wave processes. A facies map of the Fifth beds was constructed to illustrate this interpretation (Fig. 64). On the delta front, sediment-laden fluvial currents interacted with basinal processes (Reading, 1996). The fluvial dominated delta was characterized by three distributaries from the east. Sand was deposited as channel fill that eroded into the sequence as the delta prograded seaward (Pettijohn et al., 1987). As sediment was delivered to the sea to the north, wave energy and littoral drift was sufficient enough to rework sediment into a barrier bar. This may suggest sediment supply was waning to the north and delta switching was occurring. 


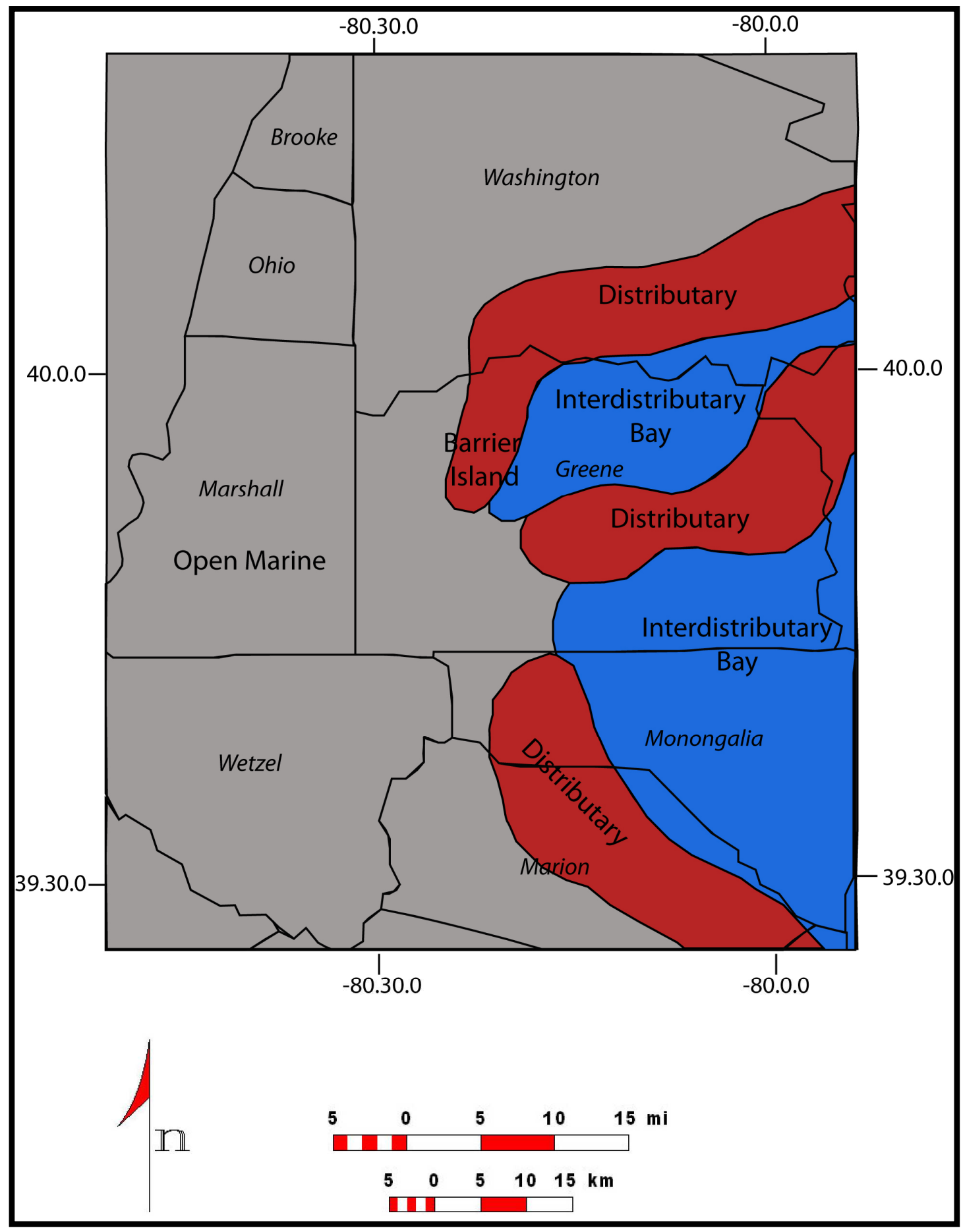

Figure 64. Paleogeographic reconstruction of the Fifth beds. 
In between the distributary channels lay the inter-distributary bay environment. This region of the delta comprises the majority of the area on the deltaic plain, and represents the lowest-velocity environments. (Davis, 1983). Sediment delivered to these areas is primarily due to flooding by rivers or storms. Interdistributary bays are generally shallow with depths ranging from a few meters in open bays to supratidal in marsh areas flanking the bays (Davis, 1983).

\section{Fourth beds}

The isopach map generated for the Fourth beds show trends similar to the Fifth beds (Fig.50). Several digitate thicks extend westward across the study area like fingers. The digitate nature and trend of the SE thicks suggest deposition occurred in a fluvialdominated delta-front environment. A paleogeographic reconstruction of the Fourth beds was constructed to illustrate this interpretation (Fig. 65). Each digitate thick represents a distributary channel transporting sediment to the sea. Basinal processes such as waves and longshore currents swept sediment southward from the distributary mouth and parallel to the shoreline forming a barrier bar and embayment behind the barrier in the north. These barrier bars indicate that wave action was also an important part of deposition of the Fourth beds and that the Fourth delta was influenced by a mixed energy depositional regime. 


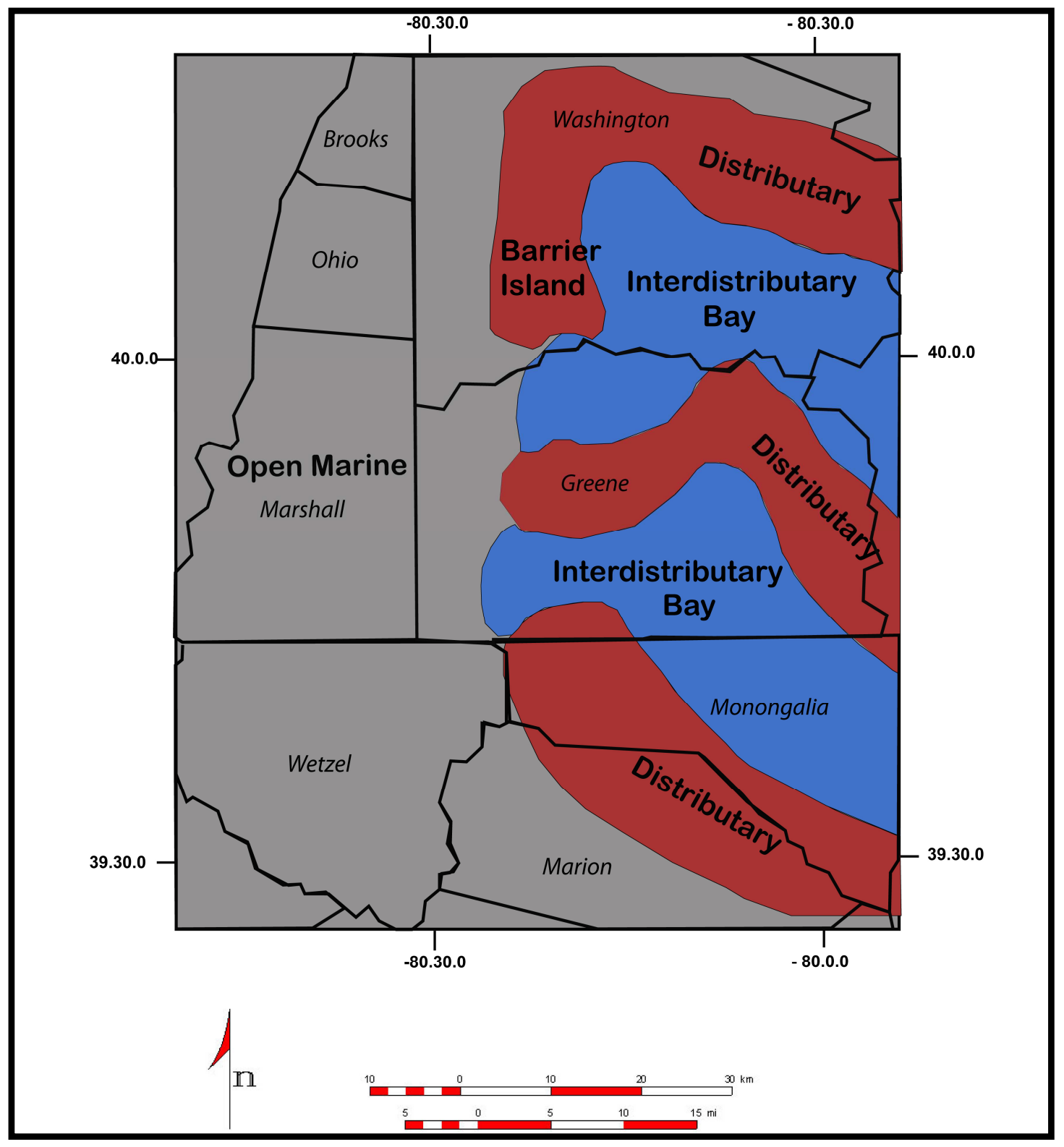

Figure 65. Paleogeographic reconstruction of the Fourth beds. 


\section{Fifty Foot Beds}

The net sandstone map produced for the Fifty Foot beds (Fig. 55) shows three shoreline parallel sandstone thicks, trending due north across Greene and Washington counties, and another sandstone body trending NNE in Monongalia and Marion counties. The sandstone geometry and blocky to concave gamma-ray response observed across the study area suggest that these sandstone thicks were deposited as barrier islands. A paleogeographic reconstruction of the Fifty Foot beds was produced to illustrate the interpretation (Fig. 66). Other workers, including McDaniel (2006) have also interpreted the Fifty Foot beds as being deposited as barrier islands. Boswell (1987) interpreted Fifty Foot beds in northern West Virginia as offshore bars because marine rocks are observed farther to the east in outcrop. Wells with a spiky or seriated gamma-ray pattern (interbedded siltstone and shaly sandstone) suggest a lagoonal environment behind the barrier system. To the east of the barrier islands in Greene and Washington Counties, one meandering sandstone thick is observed trending due south and then turning north across northern Greene County.

The geometry observed in the net sandstone map and the gamma-ray patterns observed including the multiple stacking of clean sandstone suggests that this is a meandering channel cutting across the coastal plain. Additional well logs adjacent to the channel show that Fifty Foot beds display a seriated gamma-ray pattern suggesting that these areas are the over banks of the channel. To the south of this in southeastern Greene County, a second dip-trending sandstone body with a fining-upwards gamma-ray response is observed coming from the east. The geometry, trend and gamma-ray response suggest that this is a small channel. 


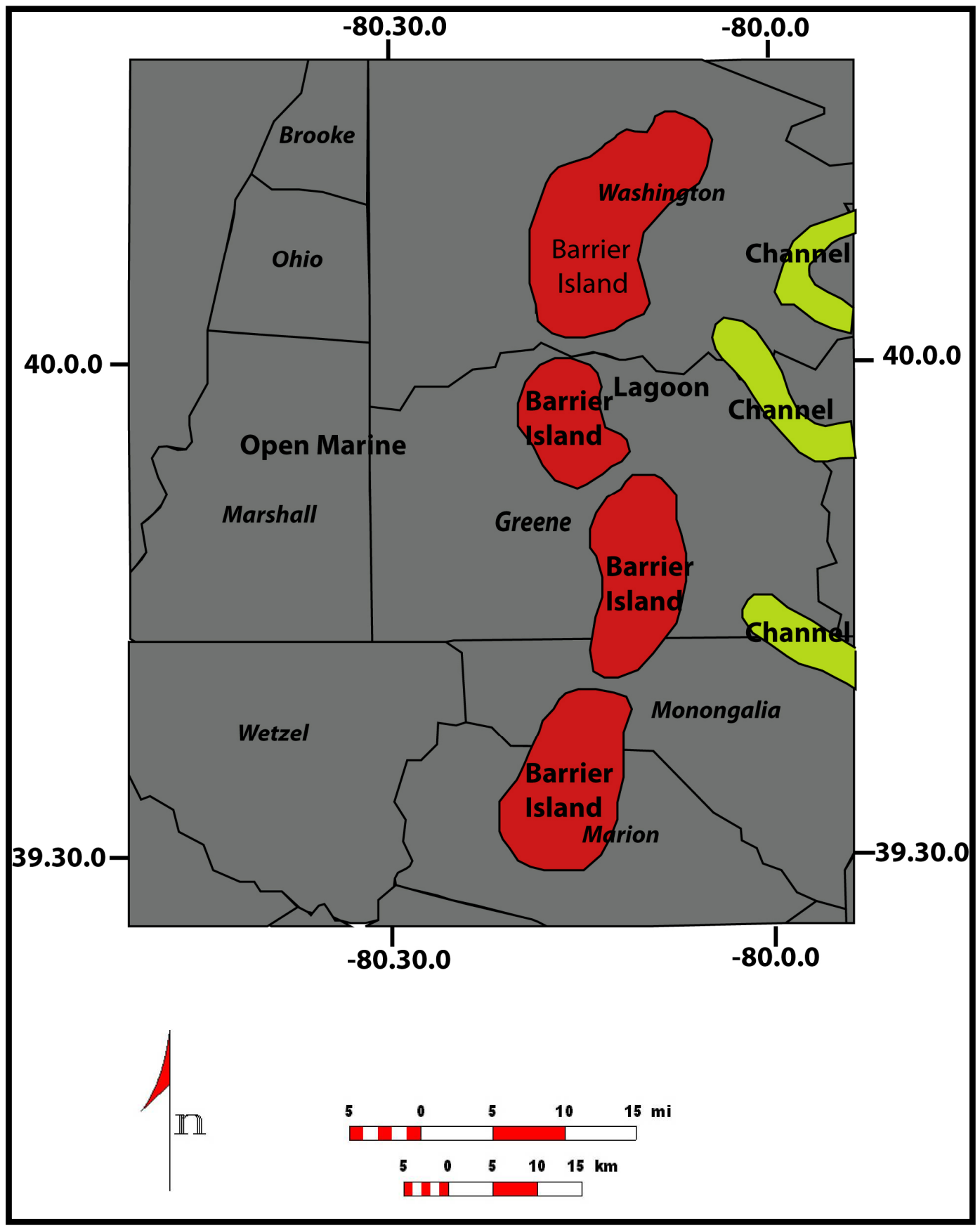

Figure 66. Paleogeographic reconstruction of the Fifty Foot beds. 


\section{Thirty Foot Beds}

The net sandstone map produced for the Thirty Foot beds shows one main shoreline parallel thick trending NNE across Greene and southern Washington Counties. A second thick is apparent in northern Washington County. The sandstone geometry and blocky to tongue-like gamma-ray response observed in well logs suggest that the Thirty Foot beds were deposited as barrier bars. Others including Boswell (1987), have also interpreted the Thirty Foot beds as barrier islands. A paleogeographic reconstruction of the Thirty Foot beds was created to aid in this interpretation (Fig. 67). Sandstone distribution patterns suggest there was one barrier island situated in Greene County and southern Washington County. A second possible barrier island was to the north in Washington County. Based on sandstone geometry, a possible flood-tide delta and tidal channel were present to the east in southern Washington County. Well logs in the area behind the barrier show a spiky gamma-ray response suggesting a lagoon or marsh environment on the landward side of the barriers. Well control to the south is poor in Monongalia and Marion counties. 


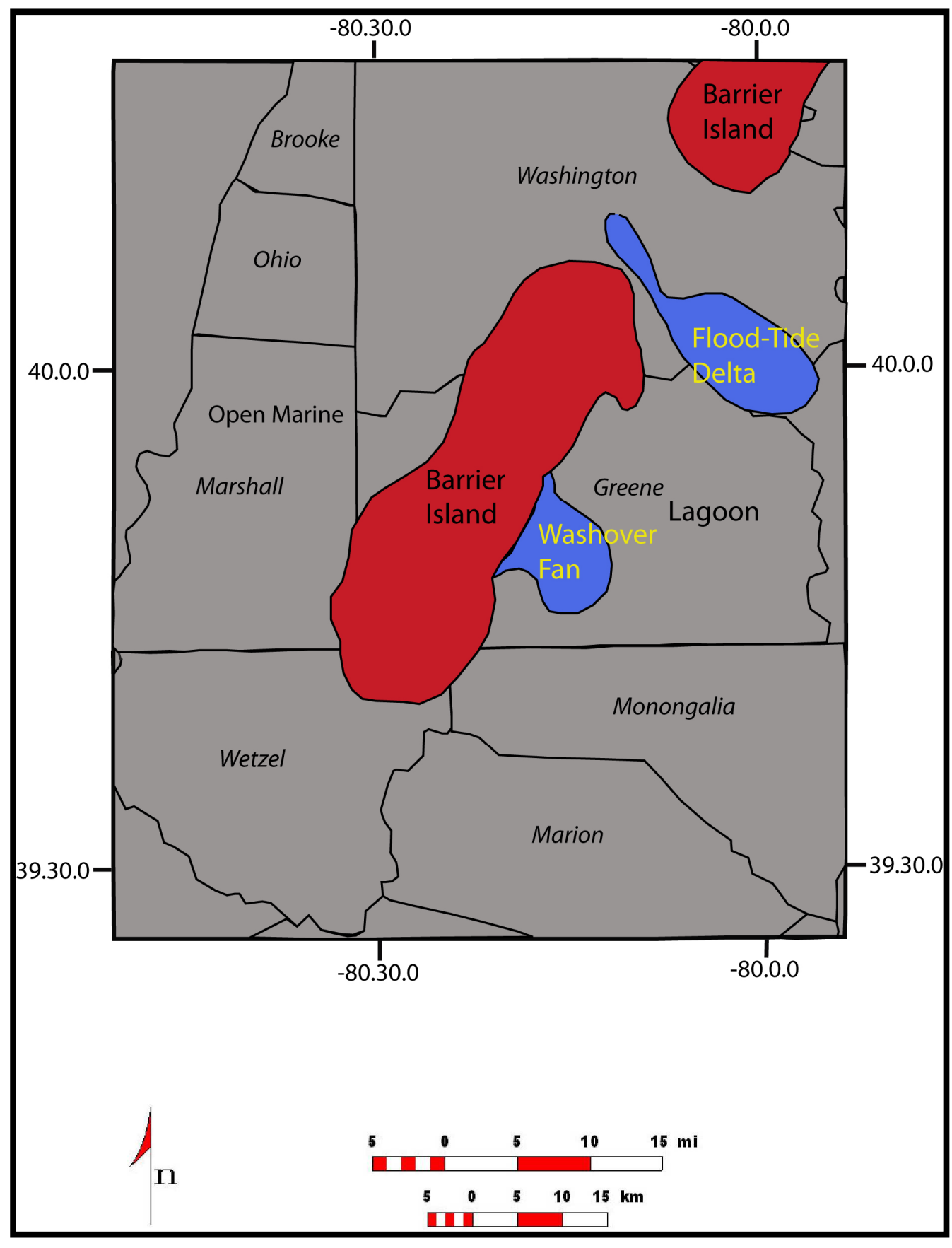

Figure 67. Paleogeographic reconstruction of the Thirty Foot beds. 


\section{Gantz Beds}

The geometries observed in the net sandstone map for the Gantz beds (Fig. 57) suggest that deposition occurred in a mixed, fluvial-deltaic and nearshore wave dominated environment similar to the environment interpreted for the Fifth and Fourth beds (Fig. 64, 65). A paleogeographic reconstruction of the Gantz beds was created to illustrate this interpretation (Fig. 68) To the east, one meandering distributary channel can be seen trending due south cutting across Greene and Monongalia counties. Well logs displaying a seriated gamma-ray response, represented by alternating clean stacked channel sandstone and shale back up this interpretation. The net sandstone map shows that the trend turns to the northwest parallel with the shoreline suggesting that a barrier Island had formed due to wave action at the mouth of the distributary. Well logs show that the Gantz beds display a blocky gamma-ray pattern further supporting this interpretation.

To the north in Washington County, another barrier bar is suggested by the shoreline-parallel trend observed in the net sandstone map. Well logs show that the Gantz beds display a blocky gamma-ray pattern here. To the south in Marion County, yet another barrier bar is suggested by the sandstone geometry. There, Gantz beds show clean sandstone displaying a blocky gamma-ray pattern. The lack of sandstone and increase in shale observed in the well logs behind the barrier island suggest a low energy bay environment in central Greene County. 


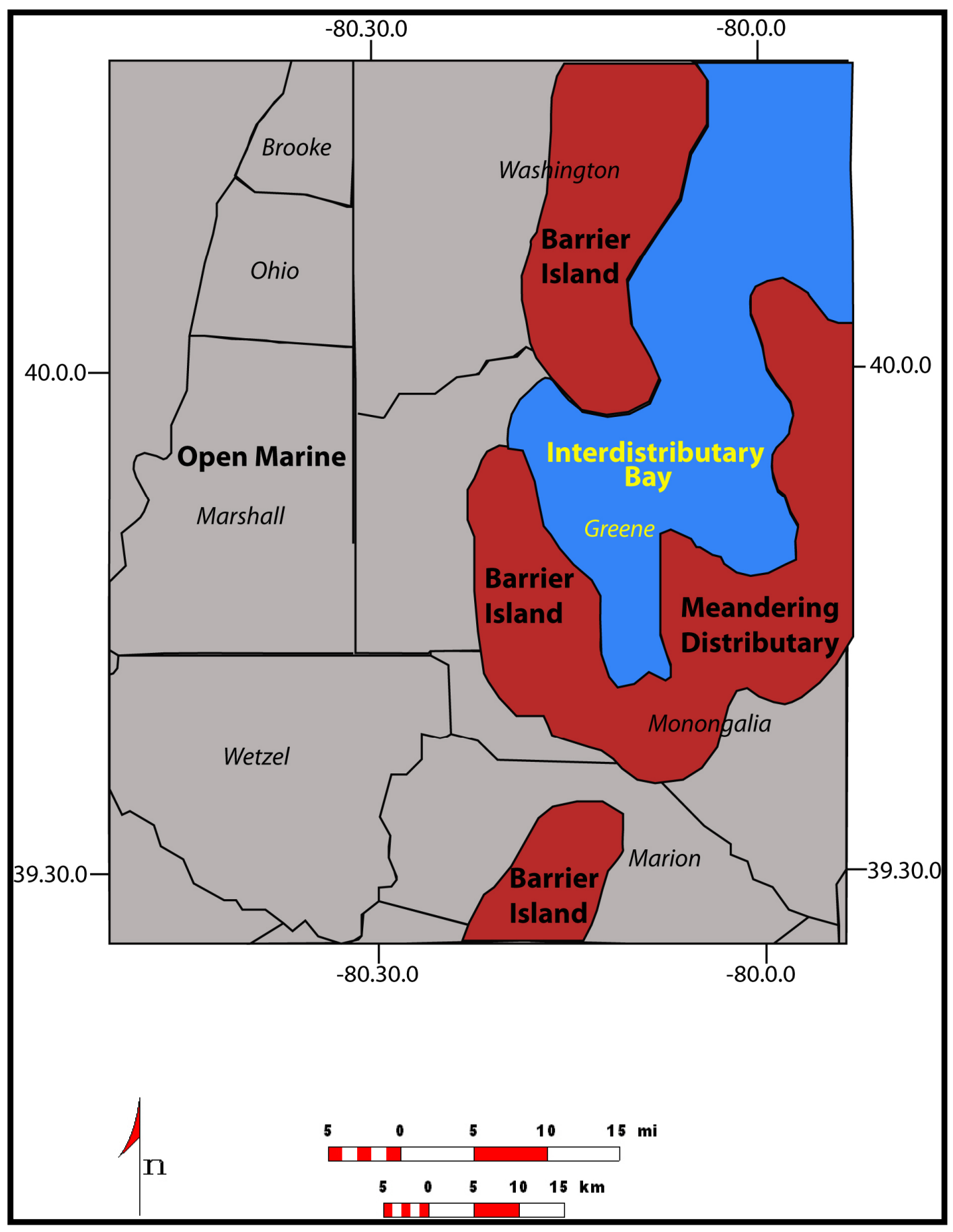

Figure 68. Paleogeographic reconstruction of the Gantz beds. 


\section{STRUCTURAL CONTROL ON SEDIMENTATION}

Vertical stacking patterns observed in well logs and abrupt thickening of beds from east to west (Fig. 69) from Fifth through Gantz time suggest some structural control on deposition. In addition, the interpreted shorelines remained nearly unchanged with only minor fluctuations in geographic position, with the exception of the Gordon Stray in Northern West Virginia. A map displaying the approximate position of the shoreline through the time interval is presented to illustrate the interpretation (Fig. 70). Shoreline position for each bed was picked where sandstone reached $10 \mathrm{ft}$. or less to the west. It is important to note that this map is only an approximation, and does not represent exact shoreline position but merely reflects the westernmost extent of sandstone deposition.

Boswell and Donaldson (1988) speculated that perhaps subsidence within the Rome Trough may have restricted the response of the shoreline to sea-level change. In a uniformly subsiding basin, the shoreline position is expected to change through time due to normal delta switching caused by avulsion and to eustatic fluctuations. Furthermore, global eustatic sea level is believed to have been rising throughout the Latest Famennian (Fig. 71) (Boswell and Donaldson, 1988). Other workers, including Woodward (1961), Wagnor (1976), Piotrowski and Harper (1979), and Gao et al. (2000), have recognized similar depositional trends within the Appalachian basin that may have been related to basement structure. Vertically stacked sandstone beds suggest that differential subsidence was occurring in the basin, creating and maintaining accommodation space for sediment to aggrade along a single linear feature. 


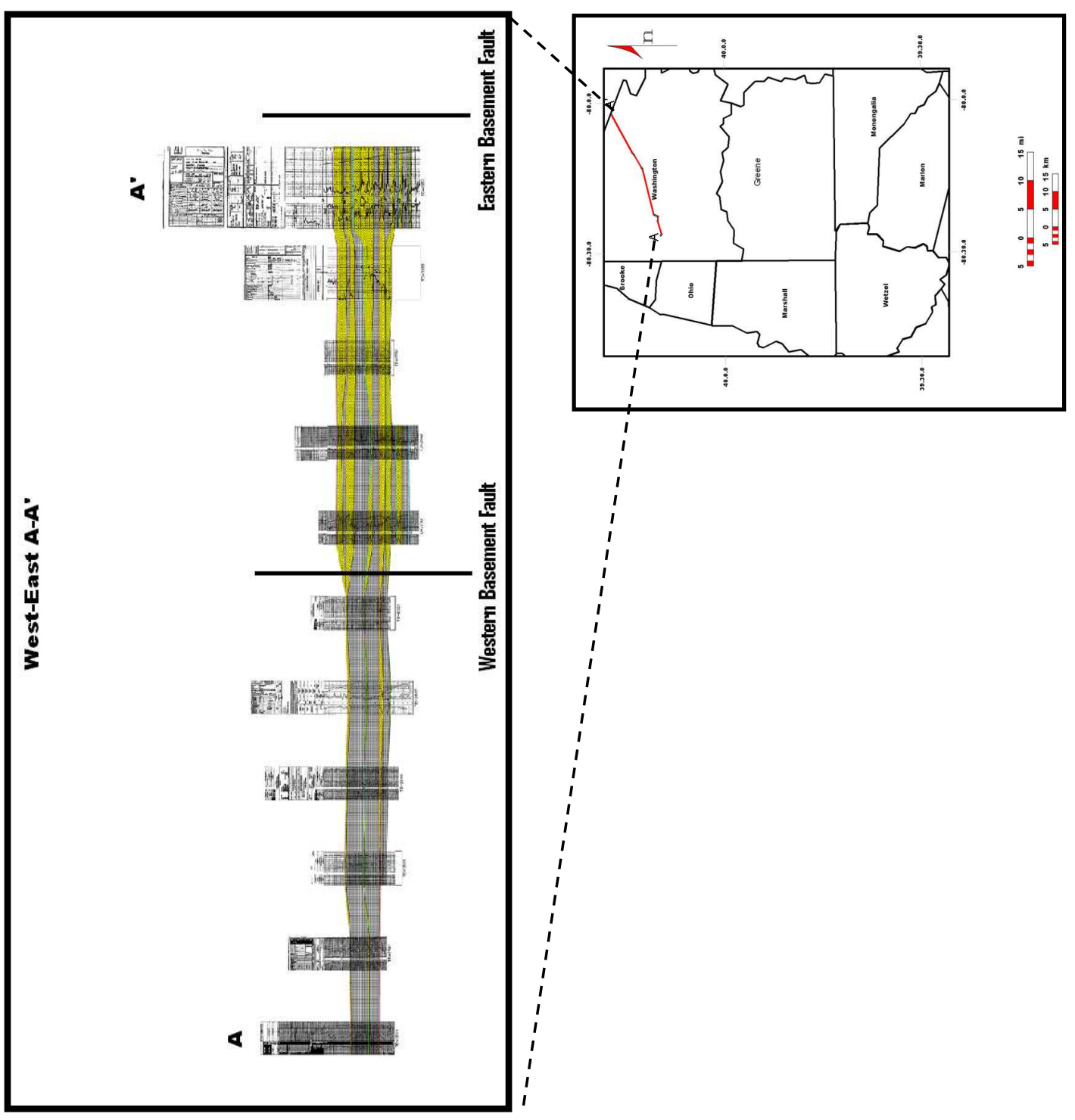

Figure 69. West-east cross section (A-A') showing abrupt thickening of sandstone beds across the study area and approximate position of basement faults in the study area. 


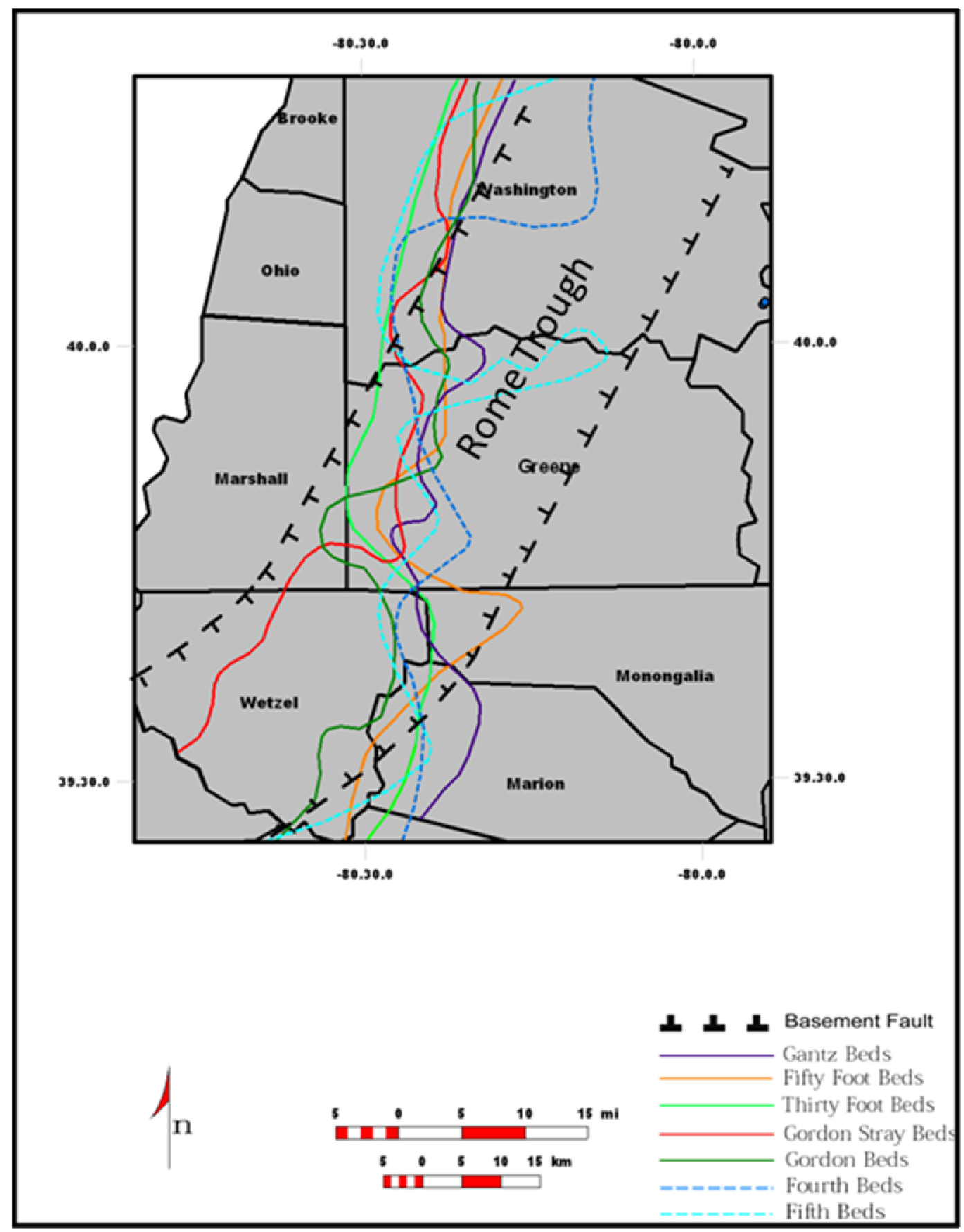

Figure 70. Map displaying approximate positions of paleoshorelines during late Devonian time in relation to the Cambrian and Ordovician basement faults from Wagner (1977). Approximate position of paleoshorelines based on western most extent of sandstone. 


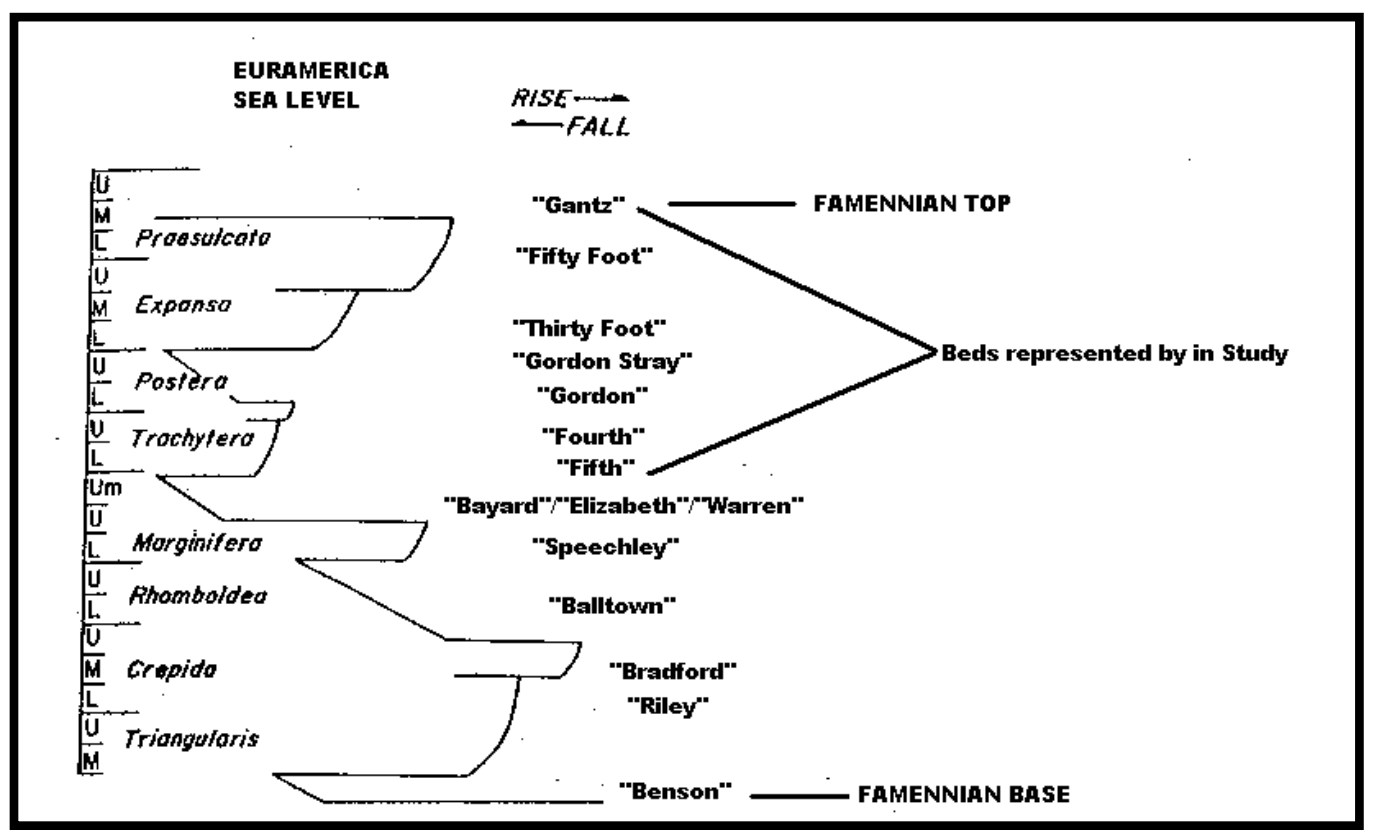

Figure 71. Euramerica sea level curve through the Late Devonian and corresponding cronostratigraphic position of sandstone beds. Bed positions adopted from Boswell and Donaldson (1988). Euramerican sea level curve and conodont biozones from Johnson and others (1984). 


\section{Gordon Beds}

Evidence for a structural control on sedimentation is suggested from both the net sandstone map and positioning of the suspected basement faults in the field area (Fig. 31). From the net sandstone map, the thickest Gordon beds occur on the eastern side of the western basement fault zone. Little sandstone deposition occurred on the eastern side of the eastern fault. Workers, including Boswell (1996) and Gao et al. (2000) have also found evidence of structural control on sedimentation during the late Devonian.

\section{Gordon Stray Beds}

The linear trend, positioning of the basement faults and the rapid thickening of Gordon Stray beds from west to east suggest that, like the Gordon beds, the Gordon Stray beds may have been influenced by structural features across western Pennsylvania. The stacking of sandstone occurs mostly on the western side of the eastern fault zone, suggesting differential subsidence and the creation of accommodation space for sand deposition. The Gordon Stray beds may have been affected more by eustatic controls in northern West Virginia however. From the net sandstone map (Fig. 36) and the paleogeographic shoreline map (Fig. 69), it is apparent that the Gordon Stray barrier islands jumped approximately 10-12 miles west across Wetzel County. This rapid jump in shoreline position coincides with the global eustatic curve put forth by Johnson and others (1984) that shows global sea was dropping during this time, and may be an indication of a forced regression during Gordon Stray time in Northern West Virginia. 


\section{Fifth Beds}

The comparison of sandstone distribution to the inferred positions of the basement faults in the study area, suggests that control on deposition was more of a function of high sediment supply rather than basin subsidence. Some evidence of structural control is suggested by the net sandstone map, however. In the northern study area, Fifth beds trend seaward only to turn southwest, finally terminating along the eastern edge of the western basement fault. This would suggest that the western basement fault was active and subsiding creating accommodation for sediment to accumulate rather than prograde past the western extent of the fault block.

\section{Fourth Beds}

Comparing the net sandstone map to the inferred position of the basement faults suggest very little influence by the eastern basement fault on deposition of the Fourth beds; however, the shoreline trending sandstone-thick in Washington County suggests that the western basement fault may have influenced deposition.

\section{Thirty Foot Beds}

The position of the basement faults in relation to sandstone distribution suggests that structure may have influenced deposition of the Thirty Foot beds. Sandstone distribution follows a similar trend as the Gordon and Gordon Stray beds across the study area. The rapid thickening and stacking pattern of the Thirty Foot beds from west to east is further indication that these beds may have been influenced to some extent by structure within the basin. 


\section{Fifty Foot Beds}

From the net sandstone map, it is evident that the Fifty Foot beds follow a similar

trend as the Gordon, Gordon Stray and Thirty Foot beds across Pennsylvania. Crosssections across the study area show a significant increase in sandstone thickness across the western side of the eastern basement fault in central Greene County, and a noticeable increase in bed thickness on the eastern side of the western basement fault in Washington County. To the south in southern Greene County and Marion County, sandstone thickness occurs on the eastern side of the eastern basement fault.

\section{Gantz Beds}

The Gantz beds show similar trends and sandstone distribution as the Fourth and Fifth beds. The net sandstone map shows two barrier bars that trend along the same strike as previous barrier islands including the Gordon, Gordon Stray, Thirty Foot, and Fifty Foot. This relationship is further observed in well logs where to the west Gantz beds are vertically stacked across Pennsylvania. 


\section{CONCLUSIONS}

During Gordon time, a series of aggrading barrier islands traversed across the region depositing a linear belt of shoreline-parallel sandstone to the west. Ebb and floodtide delta development also occurred to the north in Washington County and to the south in Marion County suggesting some tidal influence. These barriers were periodically overtopped by storm surges that are indicated by washover sheets in the back-barrier in Marion and Greene counties.

Barrier island development continued to occur through Gordon Stray time across Pennsylvania and West Virginia. In Pennsylvania, the Gordon Stray barrier islands were positioned along the same north-south linear trend as the Gordon barriers before them. To the south in Wetzel County, the barriers jumped to the west away from the main Gordon trend. Along the length of the barrier complex, three tidal channels developed with accompanying flood-tide deltas. To the north in Washington County, an ebb-tide delta developed on the seaward side of the barrier indicating tidal influence along the northern section of the barrier. Core analysis from this location shows at least two stacked tidal channels.

Prior to the development of the straight, wave-dominated shorelines of the Gordon and Gordon Stray barriers, high sediment supply rather than wave energy dictated shoreline geometry. Preliminary work from this thesis shows that the Catskill delta shorelines of the Fifth and Fourth beds were much more digitate in nature indicating a high input of sediment being supplied from the eroding Acadian mountains to the east. During the time that the Fourth beds were deposited, three distributaries flowed from the 
east. To the north in Washington County, wave action was sufficient enough to allow the development of a small barrier bar near the mouth of the northern distributary. Two interdistributary bays developed to the east.

Similar conditions dictated the deposition of the Fifth beds. Three distributaries flowed from the east. A small barrier bar developed near the mouth of the northern distributary, and a bay environment dominated the eastern portion of the field area.

Following the development of the Gordon Stray barrier islands, wave energy continued to play a major role in barrier island development throughout the Late Devonian. The Thirty Foot and the Fifty Foot barriers that followed Gordon Stray deposition were situated along the same trend as the Gordon Zone. During Thirty Foot deposition, one prominent barrier bar developed across Greene County and another bar formed to the far north of the field area. A possible flood-tide delta formed to the east of the Greene County barrier island indicating tidal influence, and possible washover sheets developed in the back barrier due to storm surges.

The deposition of the Fifty Foot beds would follow similar trends as the Thirty Foot barriers. Three north-trending barrier bars extended across Greene and Washongton counties. A fourth barrier island developed to the south across Marion and Monongalia counties. Approximately 5-10 miles to the east of the barrier islands and lagoon, several channels formed. In Washington and Greene counties, one meandering channel flowed south and then turned north across northern Greene County. In southern Greene County, a second channel flowed from the south east.

The deposition of the Gantz beds shows similar trends as the Fifth and Fourth beds. One meandering distributary flowed from the east across southern Greene County. 
A barrier island developed near the mouth of this distributary indicating the influence of waves. To the north across Washington County, a second barrier bar developed, and an interdistributary bay was situated to the east. The presence of an interdistributary bay suggests that sea level was rising and the coastal plane was being inundated by the sea.

Basin subsidence due to the continued activity of the Rome Trough may have influenced the position of shorelines throughout the Late Devonian. Evidence for this includes the rapid thickening and stacked nature of shoreline sandstone across northern West Virginia and western Pennsylvania. The shoreline positions of Late Devonian beds including the Fifth, Fourth, Gordon, Gordon Stray, Thirty Foot, Fifty Foot, and Gantz all were deposited along one linear feature across the field area with only minor fluctuations in shoreline position.

The Gordon Stray is an exception to the south however. In Wetzel County, the Gordon Stray barrier islands jumped 10-12 miles to the west away from the main Gordon trend. This rapid change in shoreline position coincides with a global eustatic sea level drop during Gordon Stray time and may be an indication that sea level change, not structural control dominated the position of shorelines to the south. Shoreline positions of the Thirty Foot and Fifty Foot beds continued to remain fixed along the same linear feature as previous shorelines in Pennsylvania. To the south, however, across northern West Virginia, shorelines had stepped back to the east along similar trends as the previous Gordon shorelines by the time of Fifty Foot deposition. The stepping back of shorelines to the east coincides with a global eustatic rise in sea level during this time and may be further indication that to the south structural control was not as prominent as to the north across western Pennsylvania. The positioning of the Gantz barrier islands 
indicates that structural control was still influencing deposition across Pennsylvania however; the development of an embayment and the flooding of the coastal plain suggest that sea level rise was slowly overpowering the effects of subsidence due to the Rome Trough. 


\section{REFERENCES}

Ameri, S., Aminian, K., Avery, K.L., Bileso, H.I. Hohn, M.E., McDowell, R.R., and Matchen, D.L., 2001, Reservoir characterization of Upper Devonian Gordon Sandstone, Jacksonburg Stringtown oil field, northwestern West Virginia. Final report to U.S. Department of Energy, Performed under contract No. DE-AC26-98BC15104, 88 p.

Aminian, K., Benjamin., Oyerkun, Ademula, Bilgesu, H.I., Ameri, S., 2001. Petroleum geology and reservoir characterization of the Upper Devonian Gordon sandstone, Jacksonburg-Stringtown oil field, northwestern West Virginia: West Virginia Geological and Economic Survey, Publication B-45, p.1-7

Boswell R.M., 1988. Stratigraphic expression of basement fault zones in northern West Virginia: GSA Bulletin v.100 p. 1988-1998

Boswell, R.M., Donaldson, A.C., and Lewis J.S., 1987. Subsurface stratigraphy of the Upper Devonian and Lower Mississippian of northern West Virginia: Southeastern Geology, v.28, p.105-131

Boswell, R.M., and Donaldson, A.C., 1988. Depositional architecture of the upper Devonian Catskill delta complex: central Appalachian Basin USA: Second International Symposium on the Devonian System, Devonian of The World, Canadian Society of Petroleum Geologists v. 2, p.65-84

Boswell R.M., Heim R.L., Wrightstone G.R., and Donaldson A.C. 1996. Upper Devonian Venango Sandstones and Siltstones, in, Roen, J.B., Walker, B., eds., The Atlas of Major Appalachian Gas Plays: West Virginia Geological and Economic Survey, v.-25, p.63-69

Boswell, R.M., and Jewell, G.A., 1988. Atlas of Upper Devonian sandstones in the subsurface of West Virginia: West Virginia Geological and Economic Survey Circular 43, p. 143

Cant, D.J., 1992, Subsurface Facies Analysis, in Walker, R.G. and James, N.P., eds., Facies models, response to sea level change: Geotext 1, Geological Association of Canada, p 27-44 
Curtis J.B., 2002. Fractured Shale-Gas Systems: AAPG Bulletin, v. 86, no. 11, pp. 19211938

Davis, R.A., 1994, Barrier-island systems-a geologic overview, in Davis, R.A., ed., Geology of Holocene barrier-island systems: Springer- Verlag, Berlin, 1-46.

Davis, R.A. 1983, Depositional Systems-a genetic approach to sedimentary geology Prentice Hall

Gao, D., Shumaker R.C., and Wilson, T.H., 2000. Along-axis segmentation and growth history of the Rome Trough in the central Appalachian Basin. AAPG Bulletin, v.84, p.75-99.

Gerald, R.E., 1992, Transgressive barrier island and estuarine systems, in Walker, R.G. and James,N.P.,eds., Facies models, response to sea level change: Geotext 1, Geological Association of Canada, p 179-191.

Hopkins E.M., 1992. Paleogeomorphic and sedimentologic framework of Bradford and Venango Group shorelines in northern Pennsylvania: Guidebook for the Annual Field Conference of Pennsylvania Geologists, Pennsylvania Geological Survey, v.57 p.21-46

Harper J.A., and Laughrey C.D., 1987. Geology of the oil and gas fields of southwest Pennsylvania: Pennsylvania Geological Survey, $4^{\text {th }}$ ser., Mineral Resources Report 87 , p.166

Harper J.A., and Laughrey C.D., 1989. Upper Devonian and Lower Mississippian stratigraphy and depositional systems: Harper J.A., ed., Guidebook for the Annual Field Conference of Pennsylvania Geologist, Pennsylvania Geological Survey, v.54 p.35-211

Johnson, J.G., Klapper, G., and Sandberg, C.A., 1985. Devonian eustatic fluctuations in Euramerica: Geological Society of America Bullitin v. 96, p. 567-587.

McBride P.S., 2004. Facies analysis of the Devonian Gordon Stray Sandstone in West Virginia: Unpublished Masters Thesis. West Virginia University p.136 
McBride P.S., and Smosna R., 2005. Facies analysis and new exploration prospects in the Devonian Gordon Stray sandstone of West Virginia: Northeastern Geology \& Environmental Sciences, v.27, p.138-154.

McCallister J.V., Haddad K.L., and Keenan R., 2001. Underbalanced coiled-tubing drilling in a thin gas storage reservoir: a case study: Society of Petroleum Engineers, SPE 72373, p.1-10

McDaniel B.A., 2006. Subsurface stratigraphy and depositional controls on Late Devonian-Early Mississippian sediments in southwestern Pennsylvania: Unpublished Masters Thesis. West Virginia University P. 84

Piotrowski R.G., and Harper J.A., 1979. Black shale and sandstone facies of the Devonian "Catskill" clastic wedge in the subsurface of western Pennsylvania: Morgantown Energy Technology Center, Morgantown, West Virginia,EGSP Series No. 13.

Pettijohn F.J., Potter P.E., Siever R., 1987. Sand and Sandstone: Springer $2^{\text {nd }}$ edition

Reading H.G., 1996. Sedimentary Environments: Processes, Facies and Stratigraphy: Blackwell Science $3^{\text {rd }}$ edition

Wagner W.R., 1976. Growth faults in Cambrian and lower Ordovician rocks of western Pennsylvania. AAPG Bulletin, v. 60, p 414-427.

Woodward H.P., 1961. Preliminary subsurface study of southeastern Appalachian interior plateau: AAPG Bulletin, v. 45, p1634-1655. 


\title{
APPENDIX
}

\section{Core Description}

\author{
Washington County \\ Southwestern Pennsylvania
}




\section{BASE OF CORE}

\section{Unit 1}

(2522.6-2524) (1.4')

Missing

\section{Unit 2}

(2511.4-2522.6) (11.2')

Mudstone (silty), grey to dull red, very fine sand to clay. Lenticular to wavy bedded. Interbeds are slightly coarser (very fine sand to silt). Thickness ranges from 0.3 " to 1.5 ". Burrowing and bioturbation are observed in mudstone. Burrows are horizontal to subhorizontal. Diameter of burrows range from 0.13 " to 0.8 ". Bedding contacts are generally sharp.

\section{Unit 3.}

(2510.5-2511.5) (1.0')

Sandstone and shale.

Fining-upwards sequence

Basal contact gradational. At the base, very fine lower to very fine upper grey sandstone. This grades into unit above.

Unit 4.

(2509.4-2510.5) (1.1')

Sandstone and silty shale.

Fining-upwards sequence

Basal contact is sharp

At the base, very fine lower to very fine upper sandstone. This grades into light grey silty shale with thin very fine lower grey to white sandstone beds. Thickness ranges from 0.06 " to 0.26 ". Bedding contacts are generally sharp.

\section{Base of Gordon Stray}

Unit 5.

(2509.2-2509.4) (0.2’)

Very fine grey sandstone.

Small scale cross-bedding

Unit 6.

(2507.4'-2509.2) (1.8')

Conglomerate and Sandstone.

Fining-upwards Sequence

At the base, matrix-supported conglomerate. Clasts consist of quartz pebbles.

Matrix is very fine lower to very fine upper sand. This grades upwards into fine upper to medium lower quartz-cemented white to light grey sandstone. Sandstone is predominantly quartz. Sorting is moderate to good. 
Unit 7.

(2506.2'-2507.4) (1.2')

Conglomerate, sandstone and shale.

Fining-upwards sequence

Basal contact is sharp.

At the base, grain supported-conglomerate. Clasts are predominately quartz pebbles. Pebbles range from $1 \mathrm{~mm}-1 \mathrm{~cm}$. Color of conglomerate ranges from white to light grey. Towards the top, conglomerate abruptly overlain by thin beds of sandstone and shale. Contact between conglomerate and alternating sandstone and shale is sharp. Contact between shale and sandstone beds is nonplaner.

\section{Unit 8.}

Conglomerate and shale.

(2506.1-2506.2) (0.1')

Fining-upwards sequence.

Basil contact is scoured. At the base, matrix-supported conglomerate. Clasts are predominately quartz pebbles. Pebbles range from $1 \mathrm{~mm}$ to $5 \mathrm{~mm}$. Matrix is very fine lower sand. Parting of dark grey shale towards the top. Contact between shale and conglomerate is non-planer. Horizontal to sub-horizontal burrows are present in grey shale.

\section{Unit 9a}

Matrix supported conglomerate

(2506-2506.1) (0.1')

Matrix: Very fine lower sandstone. At approximately 2506 feet few shell impressions are observed (Brachiopods). Clasts are quartz pebbles ranging in size from 3-4 mm. rounded to well rounded. This grades upwards into

\section{Top of Gordon Stray}

Unit $9 \mathrm{~b}$

(2502.6-2506.1) (3.5')

Mudstone.

Grey mudstone (silty).

Unit 10.

(2502-2502.6) (0.6')

Siltstone and shale.

Fining-upwards sequence.

Basal contact is sharp.

Siltstone grades into shale near top. Color is rusty brown to light burgundy.

Unit 11.

(2500.8-2502) (1.2')

Siltstone and shale.

Fining-upwards sequence. 
Basil contact sharp.

Siltstone grades into shale near top. Color is light brown to light burgundy

Unit 12.

(2499.4-2500.8) (1.4')

Siltsone and shale.

Fining-upwards sequence.

Basal contact is sharp. Siltstone grades into shale near top.

Color is burgundy to rusty brown.

Sedimentary structures include faint ripple lamination and horizontal lamination. Fossils include small horizontal to sub-horizontal burrows. Burrows are $>1 \mathrm{~mm}$ in diameter.

Unit 13.

(2496-2499.4) (3.4')

Alternating sandstone and siltstone.

Lenticular bedding.

Basil contact sharp. Color is rusty brown to light burgundy.

Fossils include horizontal to sub-horizontal burrows.

Burrows are 2-7 $\mathrm{mm}$ in diameter.

Unit 14.

(2495.4-2496) (0.7')

Siltstone and shale.

Fining-upwards sequence.

Basil contact is sharp

Siltstone grades into silty mudstone

Color is light grey to brown

Unit 15.

(2494-2495.4) (1.3')

Alternating sandstone, siltstone and shale.

Basil contact is sharp. Thickness of siltstone beds are 0.16"-3".

Thickness of shale beds are between $0.50 "-0.75 "$.

Unit 16.

(2493.8-2494) (0.2')

Siltstone and shale.

Fining-upwards sequence.

Siltstone grades into shale near the top. Color is grey.

Unit 17.

(2493.4-2493.8) (0.4')

Very fine lower sandstone and silty shale.

Fining-upwards sequence.

Basal contact is non-planer.

Sandstone grades into shale near top. 
Color is light grey.

Unit 18.

(2492.4-2493.4) (1.0')

Siltstone and silty shale.

Fining-upwards sequence.

At the base, grey siltstone. This grades into silty shale near the top. Structures include ripple lamination in the fine sandstone at the base of sequence. Fossils include small sandstone-filled horizontal burrows near the top. Diameter of burrows range from .3$.5 \mathrm{~cm}$. Color is whitish grey to light grey.

Unit 19.

(2454-2492.4) (38.4')

Very fine sandstone, siltstone and shale

Fining-upwards sequence

At the base, very fine light grey sandstone. This grades into grey, fine siltstone and shale up-section. Structures include fine horizontal lamination in fine sandstone at the base. Small horizontal burrows are visible at a depth of 2484.5 feet. Burrows average $.5 \mathrm{~cm}$ in diameter. Section missing 2464-2463.6.

Unit 20.

(2453.4-2454.9) (1.5')

Fine lower to fine upper sandstone and shale.

Fining-upwards sequence.

Basal contact is non-planer surface.

At the base, fine lower to fine upper whitish grey sandstone.

Horizontal to sub-horizontal burrows are present.

Diameter of burrows ranges from 1-5 mm.

Fossils include possible plant fragments on surface between sandstone and shale .

This grades into grey shale towards top.

Unit 21.

(2453.4-2453.6) (0.2')

Sandstone and shale.

Fining-upwards sequence.

Basal contact non-planer.

At the base, very fine lower sandstone.

Color is grey to white.

Horizontal laminations are visible in the sandstone bed.

Sandstone grades upward into grey shale. Shale is 0.5 " thick. Horizontal burrows are visible in the shale. Burrows are sand-filled and the diameter averages $1 \mathrm{~cm}$.

Unit 22.

(2453.3-2453.4) (0.1')

Sandstone and shale.

Fining-upwards sequence. 
Basal contact is non-planer.

At the base, very fine lower sandstone. Thickness is approximately 1" Above, sandstone transitions to grey shale. Shale bed is approximately 1" thick. A few sand-filled horizontal burrows are observed in the shale bed. Burrow diameter averages $6 \mathrm{~mm}$.

Unit 23.

(2453.2-2453.3) (0.1')

Sandstone and shale.

Fining-upwards sequence.

Basal contact is non-planer.

At the base, very fine lower grey sandstone. This fines upwards into grey shale. Contact between sandstone and shale is non-planer. Low-angle ripple laminations are observed in sandstone. Thickness of sandstone is approximately 1.4" thick. Shale is approximately $0.5^{\prime \prime}$ thick.

Unit 24.

(2452.2-2453.2) (1.0')

Sandstone and shale.

Fining-upwards sequence.

Basal contact is non-planer.

At the base, very finer lower sandstone. This grades into grey shale. Contact between sandstone and shale is non-planer. Horizontal burrows are present in the grey shale near the base of the shale unit. Burrows are sand-filled. Diameter of burrows average $5 \mathrm{~mm}$.

Unit 25.

(2451.9-2452.2) (0.3')

Sandstone and shale.

Fining-upwards sequence.

Basal contact is sharp.

At the base, very fine upper to fine lower grey sandstone with laminations. Above this, is grey shale. Contact between sandstone and shale is non-planer. Small silt-filled, horizontal to sub-horizontal burrows are present. Diameter of burrows average $5 \mathrm{~mm}$.

Unit 26.

(2451.6-2451.9) (0.3')

Interbedded grey sandstone and shale.

Basal contact is non-planer. Sandstone is very fine upper to very fine lower. Structures in the sandstone include ripple lamination. Shale is grey and contains few horizontal, sandfilled burrows. Diameter of burrows average 3-5mm.

Unit 27.

(2451.1-2451.6) (0.5')

Sandstone and shale.

Fining-upwards sequence.

Basal contact is sharp. At the base is very fine grained grey sandstone. Structures include horizontal laminations. Above the sandstone lies grey shale. Few sand-filled horizontal 
burrows. Diameter of burrows average $2 \mathrm{~mm}$.

Unit 28.

(2450.4-2451.1) (0.7’)

Sandstone and shale.

Fining-upwards sequence.

Basal contact is non-planer. At the base is very fine grey sandstone. Horizontal to subhorizontal sand-filled burrows are present near bottom of sandstone bed. Above this, horizontal lamination and load structure are present. Above the load structure, fine calcite shell fragments can be seen. This grades into grey shale at the top.

Unit 29.

(2449-2450.4) (1.4')

Sandstone and shale.

Fining-upwards sequence.

Basal contact is non-planer. At the base, very fine grey sandstone. One large vertical burrow (Cruziana) present at a depth of 2450 feet. Length is approximately 3 " and width is approximately $3 "$. Above this, sandstone grades into grey shale. Contact between shale and sandstone is sharp.

Unit 30 .

(2441.9-2449) (7.1')

Sandstone and shale.

Fining-upwards sequence.

Basal contact is sharp. At the base, very fine grained grey sandstone. Sandstone bed thickness is approximately $4 "$ thick. Structures include wavy laminations at top of sandstone bed. Above this is grey silty shale. This transitions into rust brown silty shale at a depth of 2646.4. Color changes back to grey at a depth of 2445'. Horizontal sandfilled burrows are present in the grey shale unit. Average diameter is $3-5 \mathrm{~mm}$.

Unit 31.

(2441-2441.9) (0.9')

Siltstone and shale.

Alternating light brown silty shale and siltstone.

Horizontal burrows are present in the siltier beds.

Unit 32.

$(2440-2441)\left(1.0^{\prime}\right)$

Grey silty shale.

Faint horizontal lamination is present near base of the unit.

Unit 33.

(2438.5-2440) (1.5')

Sandstone and shale.

Fining-upwards sequence.

Basal contact is non-planer. 
At the base, very fine lower grey sandstone.

Faint horizontal lamination is present near the base of sandstone bed.

Above the sandstone lies grey to lightly brown silty shale.

\section{Unit 34.}

(2436.5-2438.5) (2.0’)

Siltstone and silty shale.

Fining-upwads sequence.

Basal contact gradational with lower shale. Grey siltstone at the base grades upwards into grey silty shale.

\section{Unit 35.}

(2435-2436.5) (1.5')

Grey to brown siltstone.

Beds are light brown to grey in color.

Siltstone is finely laminated in places.

Unit 36.

(2431.5-2435) (3.5')

Silstone and shale.

Alternating siltstone and shale. Rocks are light brown to grey in color. Contacts between shale and siltstone are sharp. Horizontal lamination is present in a few siltstone beds. Few horizontal burrows are present near the base of the unit. Burrows average $3 \mathrm{~mm}$ in diameter.

\section{Unit 37.}

(2427.5- 2431.5) (4.0')

Light brown siltstone.

Rocks have blocky fracture.

Unit 38.

(2425-2427.5) (2.5')

Interbedded sandy siltstone and silty shale.

Rocks are generally grey in color with a few beds that are light brown. Horizontal lamination is present in a few siltstone beds. Cross-beds are present in coarser siltstone beds.

\section{Unit 39}

(2425-2424) (1.0')

Grey sandy siltstone

Faint horizontal laminations are present near the base

Unit 40

(2421.4-2424) (2.6") 
Grey sandstone siltstone and shale

Fining-upwards sequence

Basal contact is sharp. At the base, very fine lower grey sandstone. Low-angle ripple lamination is present in sandstone. This grades into grey siltstone and shale towards the top.

\section{Unit 41}

(2416-2421.4) (5.4')

Grey sandy siltstone, and shale.

Fining-upwards sequence.

Basal contact is sharp.

At the base, sandy grey siltstone. This grades into finer siltstones and grey shales towards the top of the unit. No structures are present in this unit.

\section{Unit 42}

(2412- 2416) (4.0’)

Grey siltstone and silty shale

Fining-upwards sequence.

Basal contact is sharp. At the base, grey siltstone. This fines upwards into silty grey shale and grey shale at the top of the unit.

\section{Unit 43}

(2407.5-2412) (4.0')

Grey to brown siltstone and shale.

Fining-upwards sequence

Basal contact is sharp. At the base, grey siltstone with few light brown siltstone beds. Siltstone has blocky fracture. This fines upwards overall into grey fissile shale.

\section{Unit 44}

(2406.7-2407.5) (0.8')

Grey VFL sandstone and shale

Fining-upwards sequence.

Basal contact is a scour surface. At the base, very fine lower grey sandstone. Above this lies grey shale. Faint cross-beds are present in the basal sandstone.

\section{Unit 45.}

(2405-2406.7) (1.7')

Grey VF sandstone, and grey to brown shale.

Fining-upwards sequence.

Basal contact is sharp. At the base, grey very fine grained sandstone. This grades into light brown to grey shale at the top. Sandstone is well sorted sandstone.

\section{TOP OF CORE}

TOTAL THICKNESS $=119.7$ ' 


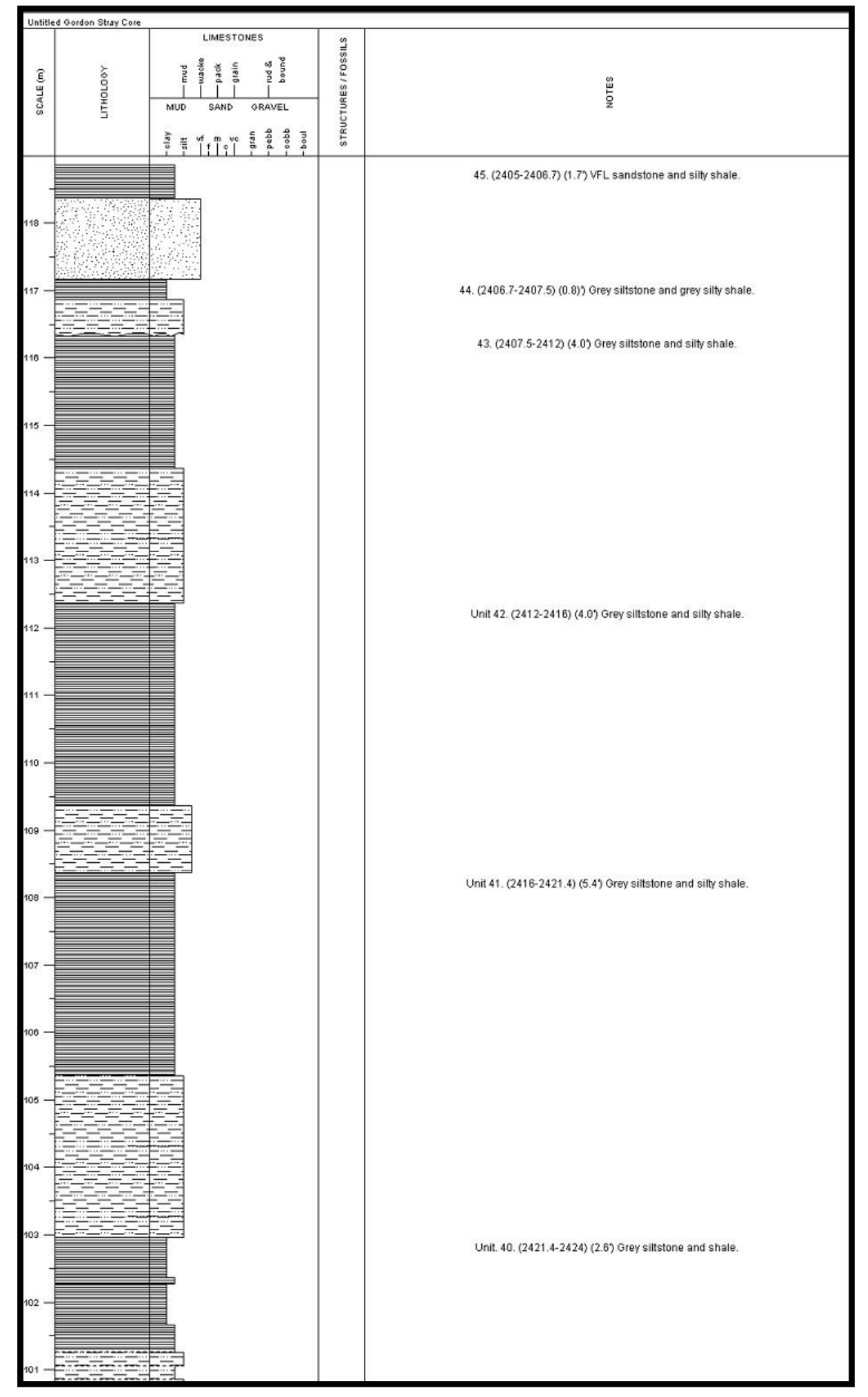




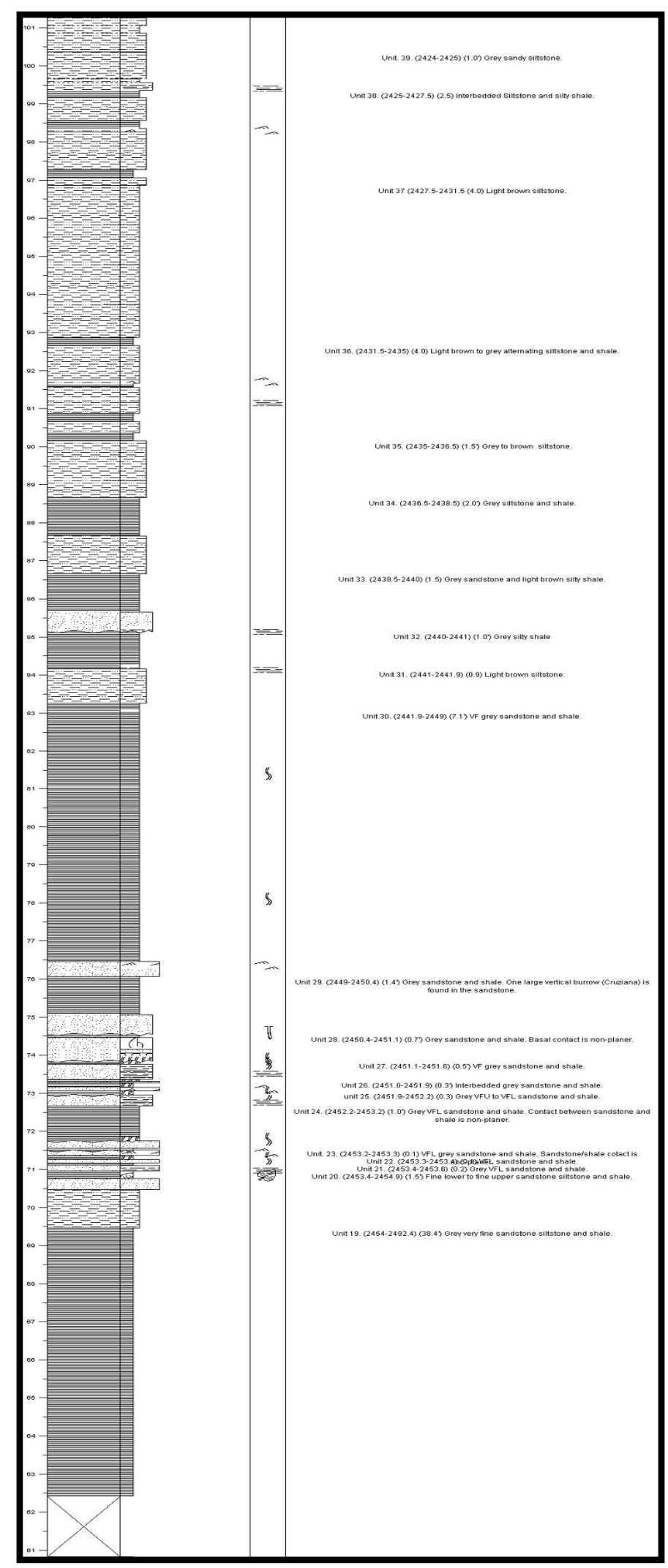




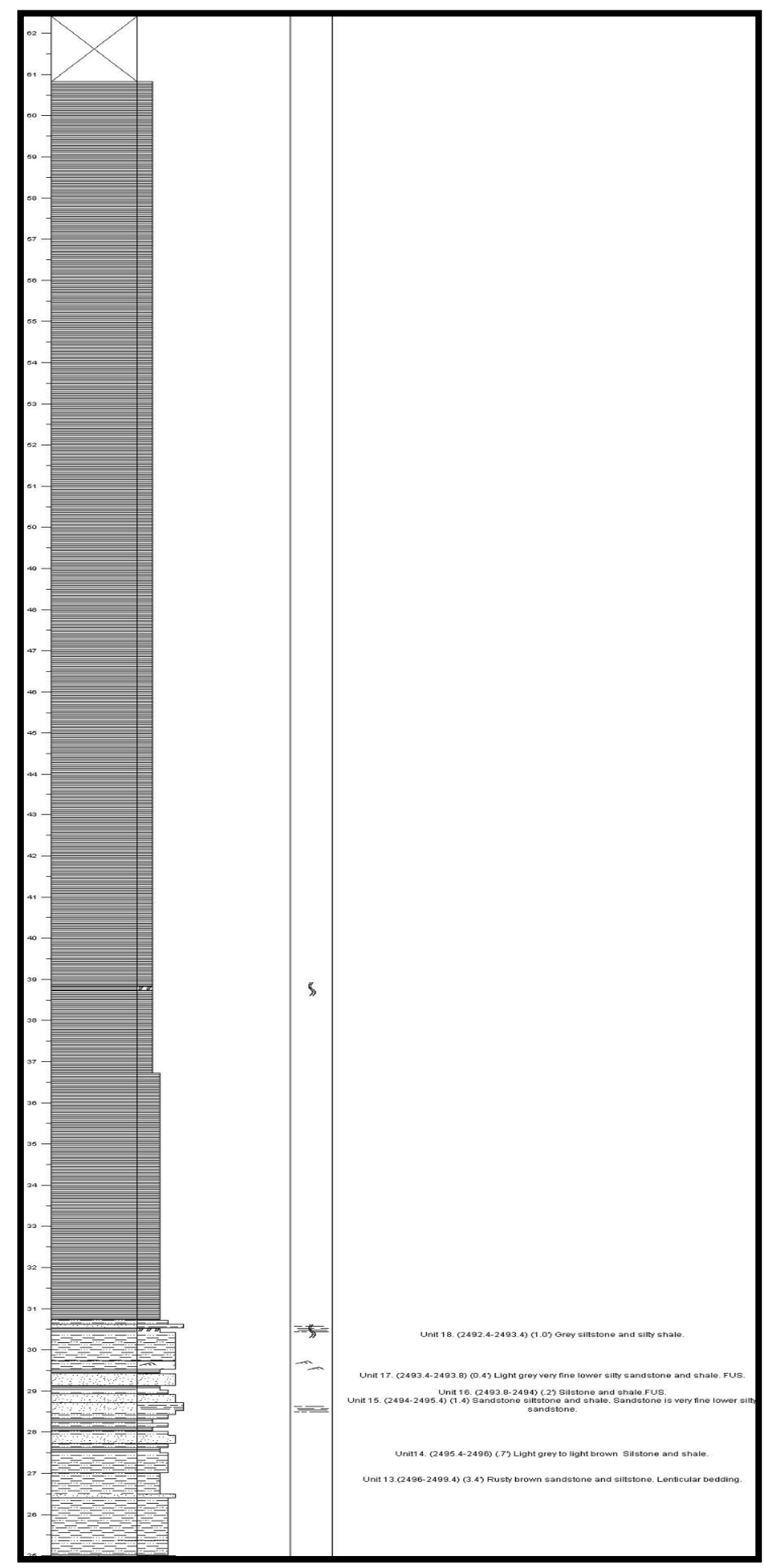




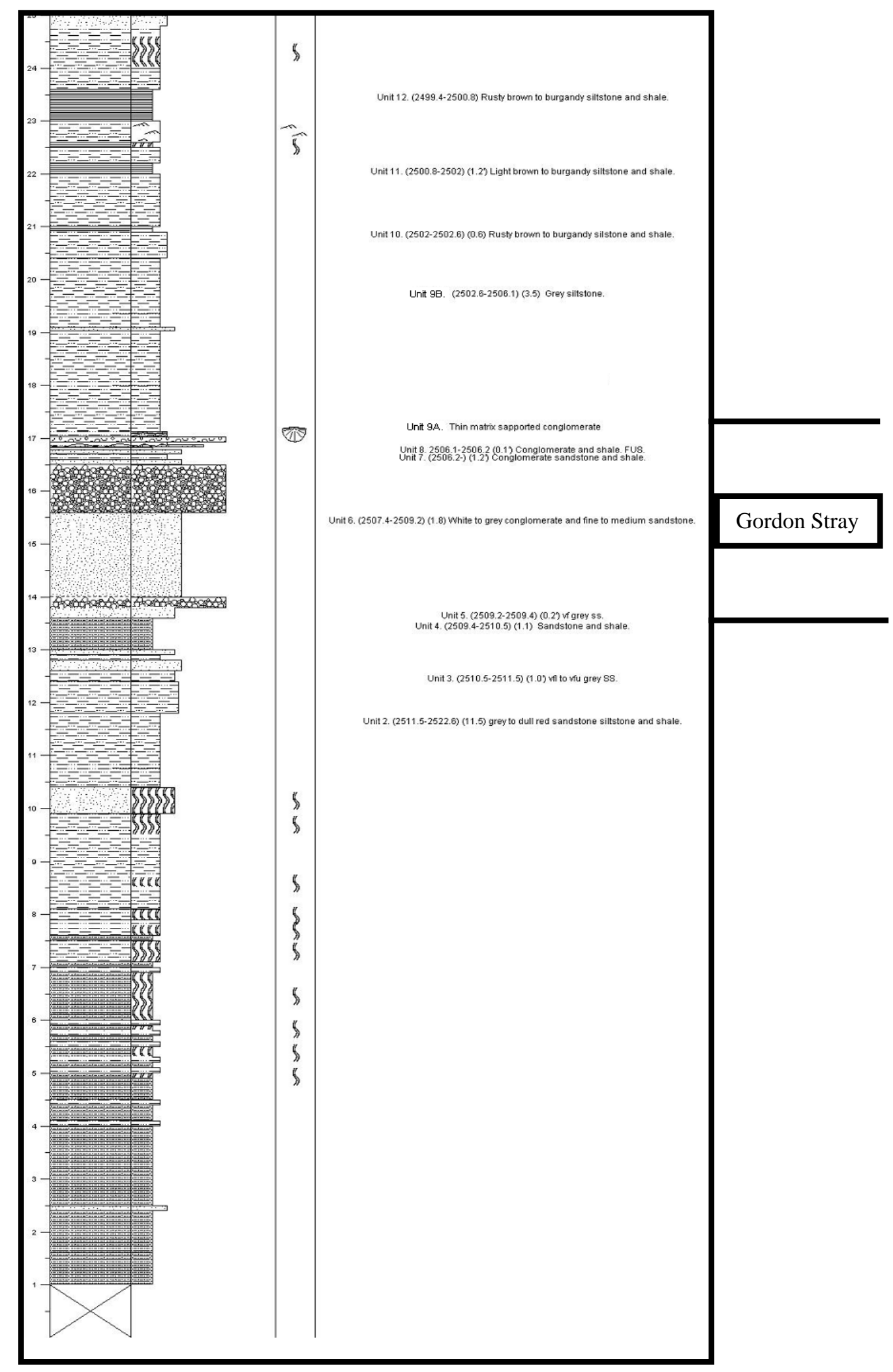

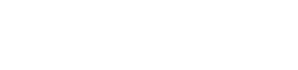
o=West Virginia
University Libraries,

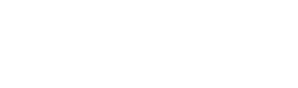

Hagen 